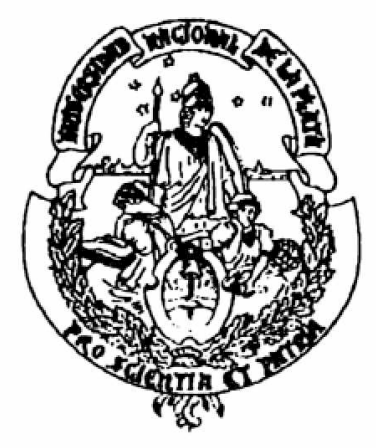

Universidad Nacional de La Plata Facultad de Ciencias Exactas

\title{
Aislamiento, purificación y caracterización de las proteasas presentes en el látex de frutos de Maclura pomifera (Raf.) Schneid. (Moraceae)
}

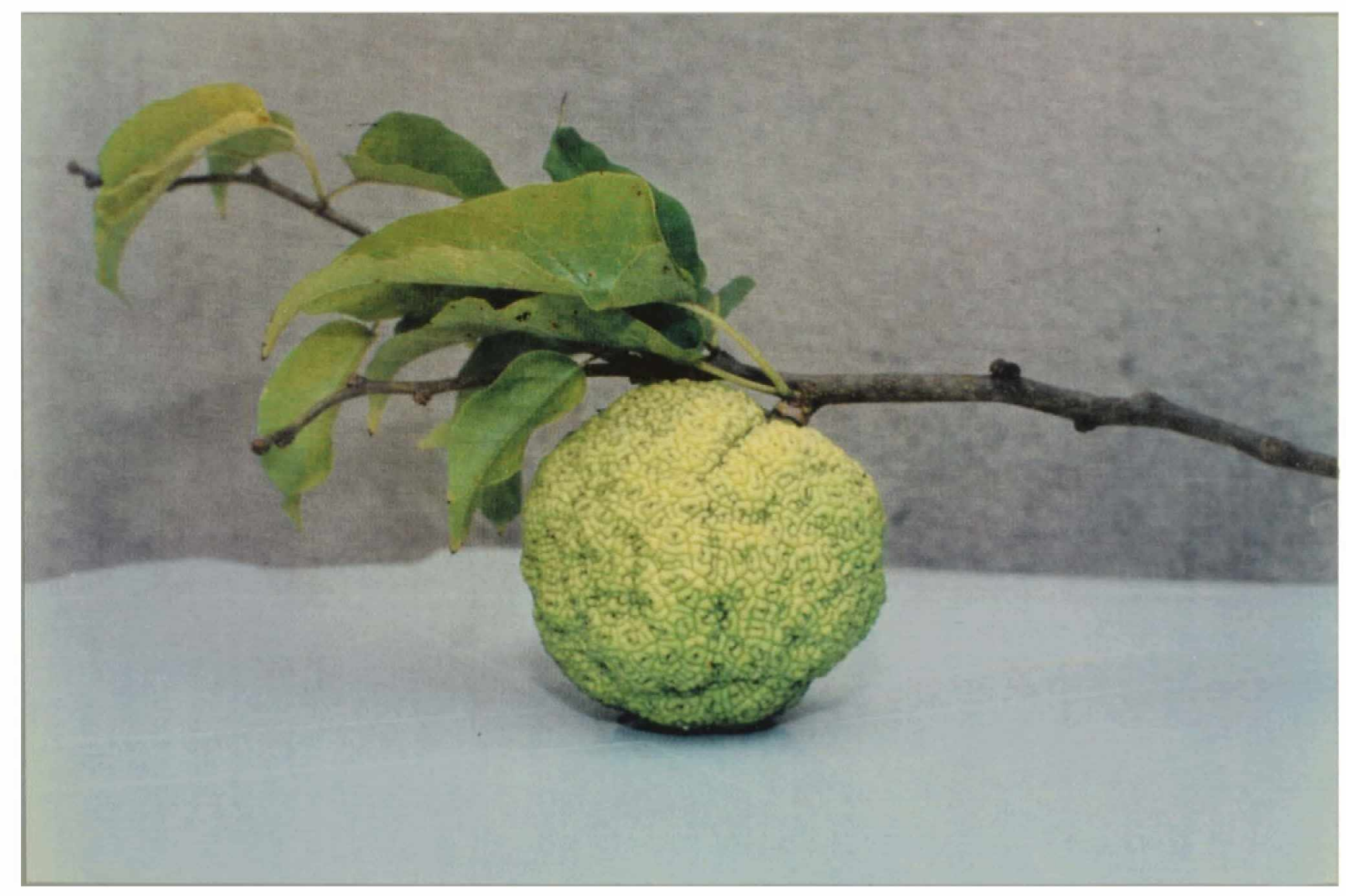

Laura María Isabel López

Tesis

1995 
A Alejandro y Ana Paula $A$ mis padres 
El presente trabajo de tesis para optar al grado de Doctor en Ciencias Bioquímicas se realizó en el Laboratorio de Investigación de Proteínas Vegetales (LIPROVE), Departamento de Ciencias Biológicas, Facultad de Ciencias Exactas, Universidad Nacional de La Plata, bajo la dirección de los Profesores Doctores Néstor O. Caffini y Claudia L. Natalucci. 
No hay un solo hombre que no sea un descubridor.

Empieza descubriendo lo amargo, lo salado, lo cóncavo, lo liso, lo áspero, los siete colores del arco y las veintitantas letras del alfabeto; pasa por los rostros, los mapas, los animales y los astros; concluye por la duda o por la fe y por la certidumbre casi total de su propia ignorancia. 


\section{Mi agradecimiento:}

al Dr. Néstor O. Caffini, quien me ha dirigido a lo largo de estos años brindándome el marco de libertad necesario para mi formación. Por haberse dedicado a discutir con infinita paciencia cada uno de los aspectos involucrados en el desarrollo de esta tesis, por su apoyo constante y generoso, tanto en lo científico como en lo personal.

a la Dra. Claudia L. Natalucci, quien ha sido una guía indispensable para mi inicio en el camino de la investigación, siempre dispuesta a transmitirme toda su experiencia y su amplia y precisa información. Por haber colaborado con gran dedicación en la ejecución de este trabajo, por su cariño, comprensión y amistad.

a las Dras. Nora Priolo y María Cecilia Arribére, excelentes compañeras de trabajo que me han alentado durante todos estos años con su cariño y amistad.

a las Lic. Adriana Brullo y Rosana Hilal, quienes supieron crear un clima de buen humor y camaradería en nuestro laboratorio.

a la Bioquímica Sara Molina que generosamente llevó a cabo la determinación de actividad proteolítica de pomiferina sobre hemoglobina.

a la Prof. Emilia M.A. Curotto Valdés, por haberme permitido, con toda amabilidad, llevar a cabo una pasantía en el Laboratorio de Bioquímica del Instituto de Química de la Universidad Católica de Valparaíso, Chile; facilitándome el material y asesoramiento necesarios para realizar las determinaciones de actividad sobre sustratos sintéticos.

a la Srta. Dora Lara, por su inestimable colaboración en el lavado cuidadoso del material utilizado en la ejecución de este trabajo. 
a la Srta. Liliana Aleksi por el diseño de tapa y el cuidadoso copiado del trabajo.

al Centro de Investigación y Desarrollo en Criotecnología de Alimentos (CIDCA), al Centro de Investigación y Desarrollo en Fermentaciones Industriales (CINDEFI) y al Instituto de Bioquímica y Biología Molecular, por facilitarme parte del equipamiento utilizado durante la realización de este trabajo.

a la Facultad de Ciencias Exactas de la Universidad Nacional de La Plata, por haberme brindado el lugar para que desarrollara el presente trabajo, así como a cada uno de los profesores que contribuyeron a mi formación profesional.

a la Comisión de Investigaciones Científicas de la Provincia de Buenos Aires (CICPBA), al Consejo Nacional de Investigaciones Científicas y Técnicas (CONICET) y a la Facultad de Ciencias Exactas (UNLP), por los medios económicos otorgados para el desarrollo de este trabajo.

a la Universidad Nacional de La Plata y al Consejo Nacional de Investigaciones Científicas y Tecnológicas por haberme otorgado las becas de iniciación y perfeccionamiento que permitieron la realización de esta Tesis Doctoral.

a mi familia que me dio fuerzas y amor. 


\section{Indice}

1.

1.1.

1.1.1.

1.1.1.1.

1.1.1.1.1.

1.1.1.1.2.

1.1.1.1.3.

1.1.1.1.4

1.1.1.2.

1.1.1.2.1.

1.1.1.2.1.1.

1.1.1.2.1.2.

1.1.1.2.1.3.

1.1.1.2.2.

1.1.1.2.2.1.

1.1.1.2.2.2.

1.1.1.2.2.3.

1.1.1.2.3.

1.1.1.2.4.

1.1.1.2.5.

1.1.2.

1.1.2.1.

1.1.2.2.

1.1.2.3.

1.1.2.4.

1.1.2.5.

1.1.2.6.

1.2 .

1.2.1.

1.2.2.

1.2.3.

1.2.4.

1.3 .

1.3.1.

1.3.2.

1.3.3.

1.3.4.

1.3.5.

1.3.6.

1.3.7.
Introducción

Proteasas: clasificación y aspectos nomenclaturales

Proteinasas o endopeptidasas

Mecanismos catalíticos de las endopeptidasas

Proteinasas serínicas

Proteinasas cisteínicas

Proteinasas aspárticas

Metaloproteinasas

Evolución de las endopeptidasas

Proteinasas serínicas

Familia de la quimotripsina

Familia de la subtilisina

Otras endopeptidasas serínicas

Proteinasas cisteínicas

Familia de la papaína

Familia de las calpaínas

Otras endopeptidasas cisteínicas

Proteinasas aspárticas

Metaloproteinasas

Proteinasas de mecanismo catalítico desconocido

Peptidasas o exopeptidasas

Aminopeptidasas o aminoacil peptidasas

Dipeptidil y tripeptidil peptidasas

Carboxipeptidasas

Peptidil dipeptidasas

Dipeptidasas y tripeptidasas

Omega peptidasas

Proteasas de látex

Proteasas de Asclepiadaceae

Proteasas de Caricaceae

Proteasas de Euphorbiaceac

Proteasas de Moraceac

Principales aplicaciones de las protcasas

Tiernización de carnes

Elaboración de cerveza

Elaboración de quesos

Panificación

Obtención de proténas modificadas para la industria alinentaria

Aditivos en polvos detergentes

Manufactura de cueros
1

2

5

6

8

10

12

14

15

15

18

19

19

20

20

21

21

23

24

25

25

27

27

27

28

28

28

29

30

32

34

36

36

37

37

38

38

39

39 
$\begin{array}{lll}\text { 1.3.8. } & \text { Industria textil }\end{array}$

1.3.9. Acción farmacológica 40

2. Objetivos 4l

2.1. Motivos de la elección del tema 41

2.2. Finalidades especificas 41

3. Materiales y métodos 43

3.1. Material vegetal 43

3.2. Relación entre el grado de madurez de los frutos, la producción

3.3. Obtención de las preparaciones crudas 44

3.4. Ensayo de la actividad proteolítica 45

3.4.1. Caseína 45

3.4.2. Azocaseína 46

3.4.3. Azocolágeno $\quad 47$

3.4.4. Hemoglobina 47

3.4.5. Proteínas de soja 48

3.5. Ensayo de la actividad esterolítica con sustratos sintéticos 49

3.6. Determinación del contenido de proteínas 50

3.7. Determinación del contenido de hidratos de carbono 50

3.8. Conservación de las preparaciones crudas 50

3.9. Efecto del pH sobre la actividad proteolítica 51

3.10. Efecto de la fuerza iónica sobre la actividad proteolítica 52

3.11. Estabilidad en el rango de $\mathrm{pH}$ de mayor actividad proteolítica 52

3.12. Estabilidad térmica 52

3.13. Efecto de activadores e inhibidores 53

3.14. Fraccionamiento acetónico 53

3.15. Ensayos de autodigestión 54

3.16. Cromatografía de intercambio aniónico 55

3.17. Diafiltración de la fracción no retenida por el intercambiador aniónico 55

3.18. Cromatografía de intercambio catiónico 56

3.19. Electroforesis en gradiente de poliacrilanida 56

3.19.1. Preparación de las muestras 56

3.19.1.1. Hidrolizados de soja 56

$\begin{array}{ll}\text { 3.19.1.2. } & 57\end{array}$

3.19.2. Preparación de los geles 58

3.19.3. Aplicación de las muestras $\quad 59$

3.19.4. Condiciones de corrida $\quad 59$

3.19.5. Fijación y coloración 
$\begin{array}{ll}\text { 3.20. } & 60\end{array}$

$\begin{array}{ll}\text { 3.20.1. } & 60\end{array}$

$\begin{array}{lll}\text { 3.20.2. } & \text { Preparación de los geles } & 60\end{array}$

$\begin{array}{lll}\text { 3.20.3. } & 61\end{array}$

$\begin{array}{lll}\text { 3.20.4. } & 61\end{array}$

3.20.5. Fijación y coloración $\quad 61$

$\begin{array}{lll}\text { 3.20.6. } & \text { Estimación de los pesos moleculares } & 62\end{array}$

3.21. Isoelectroenfoque $\quad 62$

3.21.1. Preparación de las muestras $\quad 62$

3.21.2. Preparación de los geles $\quad 63$

3.21.3. $\quad$ Aplicación de las muestras 63

3.21.4. Desarrollo del isoelectroenfoque $\quad 63$

3.21.5. Fijación $\quad 64$

3.21.6. Coloración $\quad 64$

3.21.7. Estimación de los puntos isoeléctricos 65

3.22. Zinograma 65

3.22.1. Preparación de las placas agarosa-caseína $\quad 65$

3.22.2. Desarrollo del zimograma 66

3.22.3. Fijación $\quad 66$

3.22.4. Coloración $\quad 66$

$\begin{array}{lll}\text { 3.22.5. Decoloración . } & 67\end{array}$

4. Resultados y Discusión 68

4.1. Relación entre el grado de madurez de los frutos, la producción de látex y el contenido en proteasas de los mismos $\quad 68$

4.2. Distribución del contenido de látex en frutos de Maclura pomifera 68

$\begin{array}{ll}\text { 4.3. } & 71\end{array}$

4.3.1. Denominación de las proteasas en estudio 71

$\begin{array}{lll}\text { 4.3.2. } & \text { Conservación de las preparaciones crudas }\end{array}$

4.3.3. Efecto de $\mathrm{pH}$ sobre la actividad proteolítica 73

4.3.4. Efecto de la fuerza iónica sobre la actividad enzimática

4.3.5. Estabilidad de las preparaciones crudas $\quad 76$

4.3.5.1. Estabilidad al pH $\quad 76$

4.3.5.2. $\quad$ Estabilidad termica 76

4.3.6. $\quad$ Efecto de activadores e inhibidores $\quad 79$

4.3.7. Expresión de la actividad proteolítica de las preparaciones

4.3.8. Ensayo de la actividad esterolítica con sustratos sintéticos $\quad 82$

4.4. Purificación $\quad 84$

4.4.1. Fraccionamiento acetónico $\quad 84$

4.4.2. $\quad$ Ensayos de autodigestión del precipitado acetónico 89

4.4.3. Cromatografia de intercambio aniónico 91 
4.4.4. Cromatografia de intercambio catiónico 91

4.4.5. Seguimiento de la purificación $\quad 93$

4.4.6. Pesos moleculares de las fracciones purificadas 95

4.4.7. Puntos isoeléctricos de las fracciones purificadas 96

4.5. Caracterización parcial de la fracción III 96

4.5.1. Efecto de pH sobre la actividad proteolítica 96

$\begin{array}{lll}\text { 4.5.2. } & \text { Estabilidad térmica } & 98\end{array}$

$\begin{array}{lll}\text { 4.5.3. } & \text { Efecto de activadores e inhibidores } & 98\end{array}$

$\begin{array}{lll}\text { 4.5.4. } & \text { Ensayo de la actividad esterolítica con sustratos sintéticos } & 101\end{array}$

$\begin{array}{lll}\text { 4.5.5. Zimograma de la fracción III } & 101\end{array}$

$\begin{array}{ll}\text { 5. Conclusiones } & 106\end{array}$

6. Referencias bibliográficas 


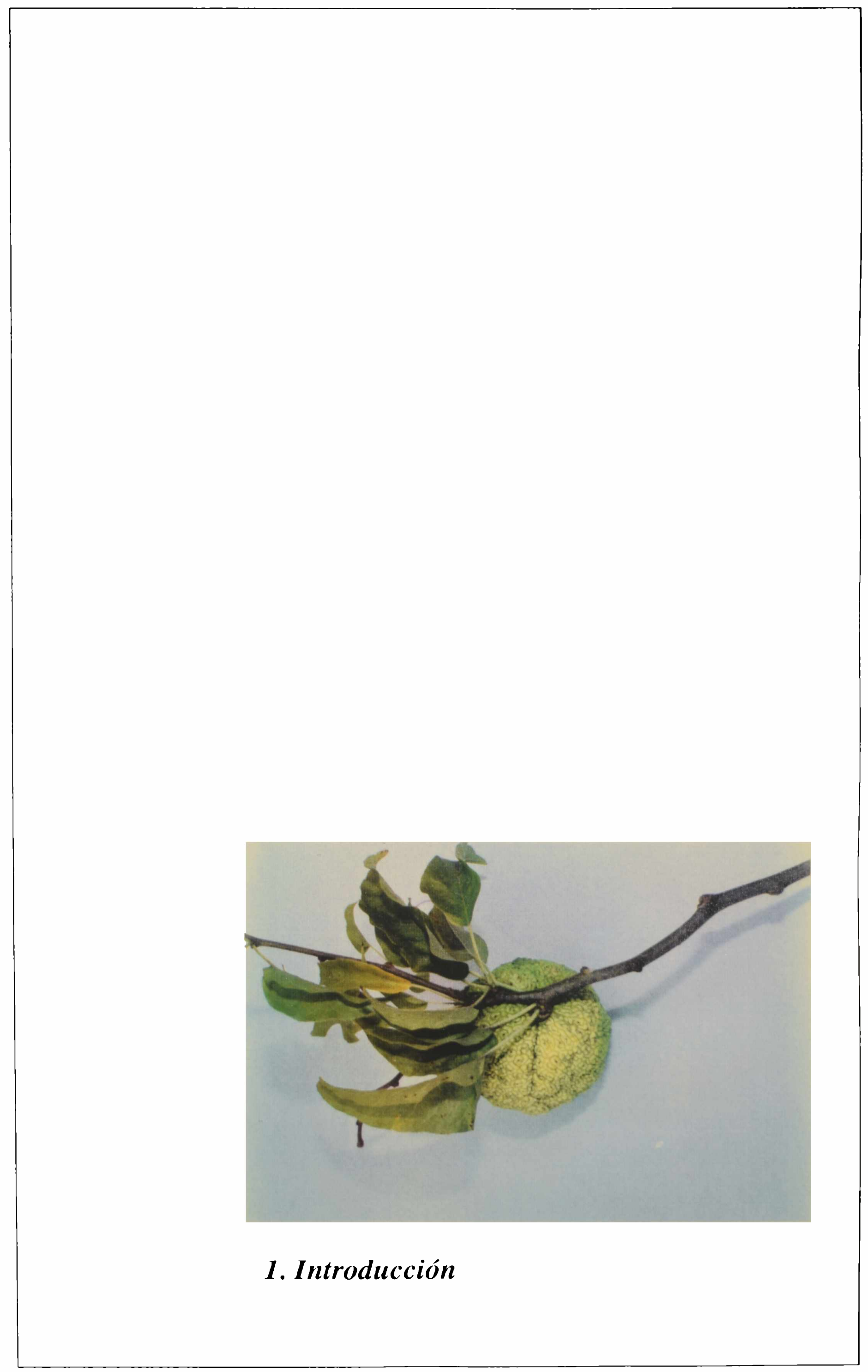




\subsection{Proteasas: clasificación y aspectos nomenclaturales}

Las enzimas que desempeñan el rol central en la degradación de las proteínas han sido conocidas tradicionalmente como "proteasas", término equivalente al de "enzimas proteolíticas" y también al más moderno de "péptido-hidrolasas", aunque ya en el año 1928 Grassman y Dyckerhoff habían establecido una importante distinción entre las hidrolasas que actúan directamente sobre las proteínas ("proteinasas") y aquellas que lo hacen sobre los péptidos que se producen durante la proteólisis ("peptidasas").

Por otra parte, durante la discusión de los mecanismos de acción hidrolítica surgieron los nombres alternativos de endopeptidasas para las que ejercen su acción en el interior de las cadenas polipeptídicas y de exopeptidasas para las que hacen lo propio a partir de los extremos (Bergmann y Ross, 1936), términos que manifiestan una obvia analogía con los que se usan para designar a las hidrolasas que actúan sobre otros biopolímeros.

Algunos años más tarde el motivo de esta distinción resultó claro: depende de la aceptabilidad o no de los grupos amino o carboxilo terminales de la cadena polipeptídica en lugares específicos de la molécula de la enzima. Así, los grupos terminales no hacen falta -y típicamente no son tolerados- en los sitios activos de las endopeptidasas, razón por la cual éstas actúan bien sobre cadenas largas, en puntos alejados de los extremos, pero su acción no es tan eficaz sobre los péptidos que aparecen como productos de la reacción inicial. En contraste, la especificidad de las exopeptidasas requiere que uno de los extremos ocupe un lugar específico dentro del sitio activo, por lo que estas enzimas ejercen escaso efecto degradativo sobre la proteína intacta, al estar limitada su acción a las uniones peptídicas cercanas al extremo.

Tanto los sitios activos de las endopeptidasas como los de las exopeptidasas cumplen el papel de permitir la unión de la enzima con el sustrato apropiado y de catalizar luego la hidrólisis de la unión peptídica específica (Mc Donald, 1985). De acuerdo con la terminología introducida por Schecter y Berger (1967), la zona de unión del sitio activo puede ser dividida en subsitios o sitios especificos (S), cada uno de los cuales permite la ubicación de un residuo aminoacídico del sustrato. Los subsitios están ubicados a ambos lados del sitio catalítico y a partir de él son numerados correlativamente, ya sea en 
dirección al extremo $\mathrm{N}$-terminal $\left(\mathrm{S}_{1}, \mathrm{~S}_{2}, \mathrm{~S}_{3}\right.$, etc.) o hacia el C-terminal $\left(\mathrm{S}_{1}{ }_{1}, \mathrm{~S}_{2}{ }_{2}, \mathrm{~S}_{3}\right.$, etc.). Los aminoácidos de la zona del sustrato que interactúa con la proteasa son numerados $\left(\mathrm{P}_{1}, \mathrm{P}_{2}, \mathrm{P}^{\prime}{ }_{1}, \mathrm{P}^{\prime}\right.$, etc. $)$ de acuerdo a los subsitios en los cuales se ubican. La fig. 1.1. ilustra esquemáticamente la interacción enzima-sustrato en las inmediaciones del sitio activo de una endopeptidasa (a) y de una exopeptidasa (b).

La mayoría de las proteasas son inconfundiblemente endopeptidasas 0 exopeptidasas, pero algunas de ellas exhiben actividad de ambos tipos. Por convención, cualquier enzima que tenga acción proteinásica distintiva es considerada como una endopeptidasa, aún cuando muestre además acción exopeptidásica.

Desde el punto de vista fisiológico, una consecuencia inevitable de las especificidades de ambos tipos de proteasas es que las endopeptidasas son las responsables de los primeros estadios de la proteolisis, en tanto que las exopeptidasas inician más tarde su acción y eventualmente completan la degradación hasta la liberación de los aminoácidos constitutivos. Como ocurre en la mayor parte de los procesos bioquímicos, es la reacción inicial (catalizada por la endopeptidasa) la que limita la velocidad de reacción; una vez que la degradación de la proteína ha comenzado, la reacción progresa rápidamente y es escasa o nula la acumulación de los productos de esa degradación (Barrett, 1986).

\subsubsection{Proteinasas o endopeptidasas}

Las proteinasas difieren de casi todas las demás enzimas en que su especificidad de sustrato resulta extremadamente difícil de definir, hecho que llevó a Hartley (1960) a proponer una clasificación de las mismas basada en las características de sus respectivos mecanismos catalíticos. A partir de esa propuesta las endopeptidasas se dividen en cuatro grupos: proteinasas serínicas (EC 3.4.21), tiolproteinasas (EC 3.4.22, actualmente denominadas proteinasas cisteínicas), proteinasas ácidas (EC 3.4.23, modernamente llamadas proteinasas aspárticas) y metaloproteinasas (EC 3.4.24), a los que debe agregarse un quinto grupo (EC 3.4.99) de existencia efímera, que incluye a proteinasas de 
a) ENDOPEPTIDASA

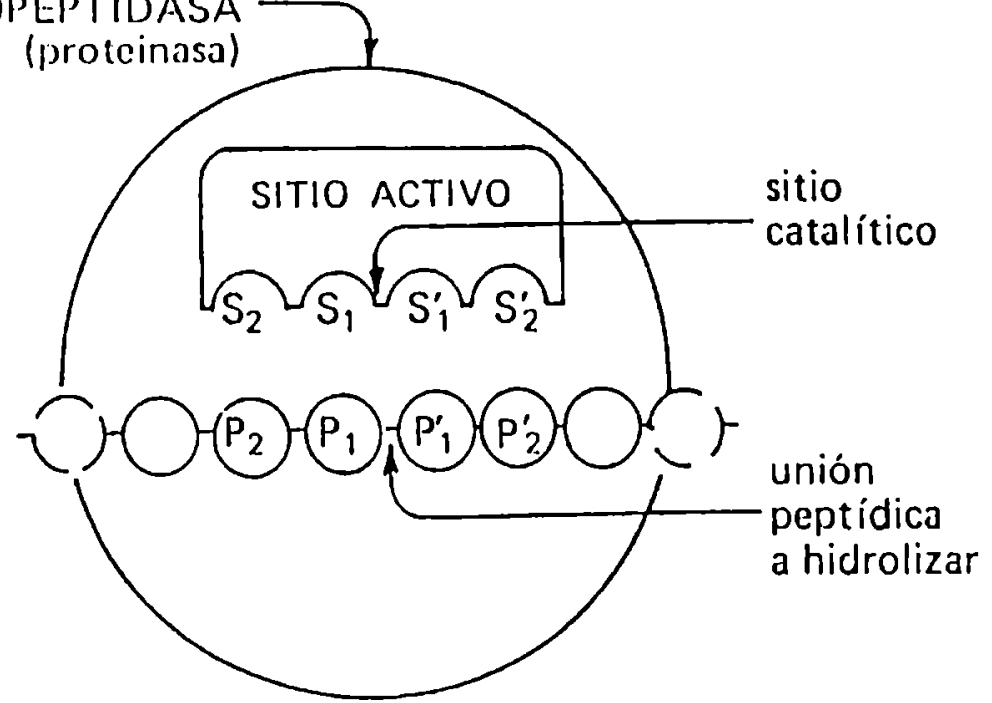

b) EXOPEPTIDASA

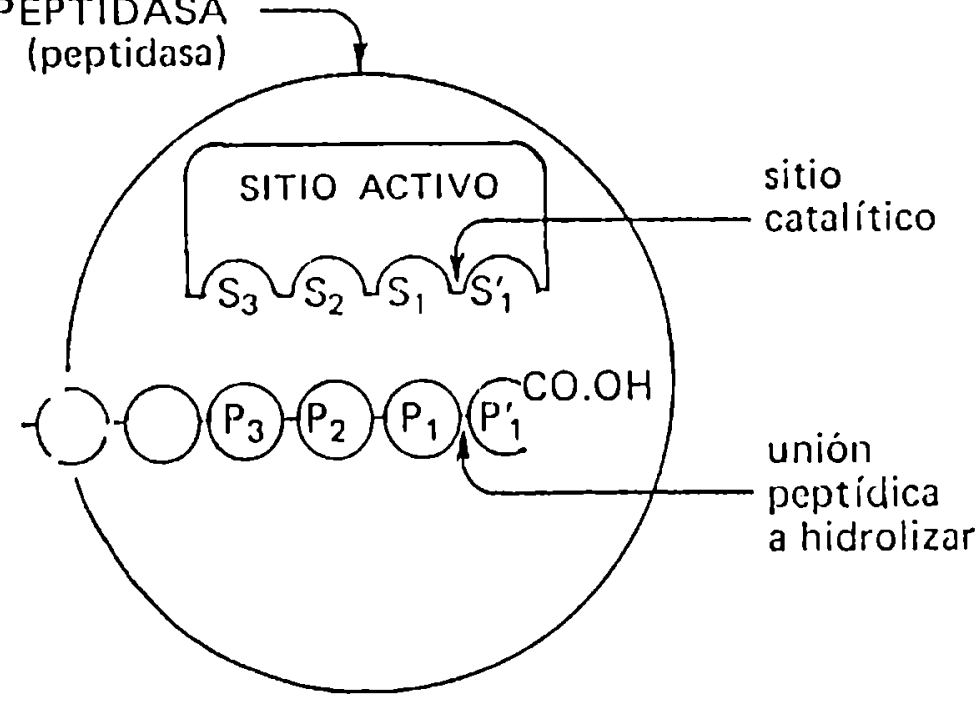

Fig. 1.1. Representación esquemática de la forma de unión entre una proteasa y su sustrato en (a) una endopeptidasa y (b) una exopeptidasa (en este caso una carboxipeptidasa). Ver en el texto la explicación de los símbolos adoptados y la terminología utilizada (Adaptado de Mc Donald, 1985). 
mecanismos catalíticos aún no identificados (Nomenclature Committee of the International Union of Biochemistry, 1984).

El mecanismo general de acción de los dos primeros grupos de proteinasas responde a un esquema que incluye la siguiente secuencia de reacciones, en la que los productos son liberados en pasos sucesivos

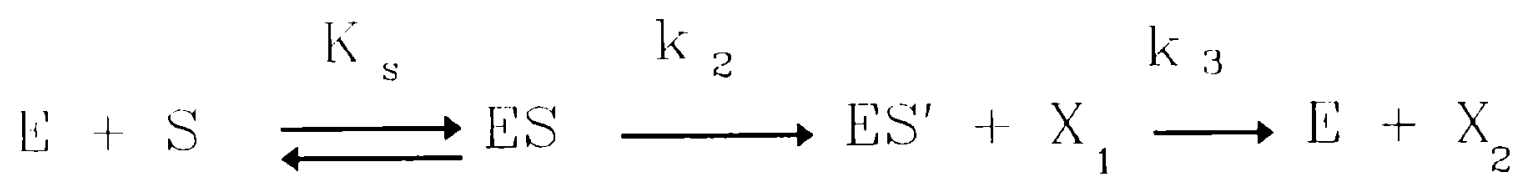

La primera etapa consiste en la formación del complejo no covalente enzimasustrato (ES), en donde $\mathrm{K}_{\mathrm{S}}$ es la constante de equilibrio. Ello implica la existencia de interacciones entre subsitios específicos de la enzima y determinadas zonas del sustrato, factores decisivos en la selectividad de la enzima por el sustrato.

En el segundo paso se produce el ataque del grupo carbonilo de una unión peptídica sensible del sustrato por parte de un grupo químico activado perteneciente al sitio activo de la enzima, lo que provoca la liberación de la porción C-terminal $\left(\mathrm{X}_{1}\right)$ de la cadena polipeptídica original, en la que su nuevo aminoácido $\mathrm{N}$-terminal proviene de la unión peptídica escindida.

La porción $\mathrm{N}$-terminal del sustrato queda asociada a la enzima y libera en una siguiente etapa el segundo producto $\left(\mathrm{X}_{2}\right)$, representado por la fracción $\mathrm{N}$-terminal de la cadena polipeptídica y en la que el nuevo aminoácido C-terminal proviene de la unión peptídica hidrolizada.

Los distintos tipos de proteinasas pueden diferenciarse en base a las siguientes características: 1) requerimiento de la existencia de determinados sitios de unión en el sustrato, que permitan la orientación correcta del mismo en la posición exigida por la maquinaria catalítica, 2) naturaleza del grupo activo de la enzima responsable de la formación temporaria de la acil-enzima (ES') y 3) identidad de los grupos que catalizan la descomposición de este intermediario (Barrett, 1986). 


\subsubsection{Mecanismos catalíticos de las endopeptidasas}

Cada una de las cuatro clases de endopeptidasas mencionadas posee un mecanismo catalítico distintivo, pero aún así pueden agruparse en dos grandes categorías: las que forman complejos covalentes entre la enzima y el sustrato (endopeptidasas serínicas y cisteínicas) y las que no forman complejos enzima-sustrato covalentes (endopeptidasas aspárticas y metaloproteinasas).

Esta distinción en dos grandes grupos mecanísticos tiene mucha importancia, ya que la estrategia para la inhibición de la acción proteolítica es diferente en las dos clases. Las endopeptidasas serínicas y cisteínicas tienen aminoácidos fuertemente nucleofílicos en sus sitios catalíticos y por lo tanto pueden ser inhibidas mediante la introducción de grupos electrofílicos al sistema. La segunda categoría incluye enzimas que catalizan la hidrólisis de uniones peptídicas sin que ningún grupo funcional participe en el ataque nucleofílico, el que está a cargo de una molécula de agua, a través de una típica catálisis ácido-base; el diseño de los inhibidores en este caso está basado en sistemas complejantes de mayor sofisticación (Dunn, 1989).

A pesar de las diferencias señaladas, debe tenerse en cuenta que el proceso principal -la escisión de la unión peptídica- es idéntico en todos los casos y que las diferencias entre los mecanismos catalíticos son mas bien sutiles. El ataque al grupo carbonilo requerirá que algún nucleófilo -ya sea oxígeno o azufre- se acerque al carbono carbonílico, que es ligeramente electrofílico. Mediante una catálisis básica se removerá un protón del nucleófilo y por algún tipo de influencia electrofílica sobre el oxígeno carbonílico se incrementará la polarización de la unión $-\mathrm{C}=\mathrm{O}$.

Los grupos específicos que llevan a cabo estas tres funciones (ataque nucleofílico, catálisis básica y asistencia electrofílica) son diferentes en las cuatro clases de endopeptidasas mencionadas, pero el resultado neto es el mismo. De igual modo, la ruptura del intermediario tetahédrico que se forma luego del ataque nucleofílico requerirá de una catálisis ácida para facilitar la partida de la porción amino del sustrato, proceso en el que participarán diferentes grupos en cada caso (Dunn, 1989). 


\subsection{Proteinasas serínicas.}

Constituyen la clase de enzimas más estudiada en el campo de las proteasas y, quizás, de toda la enzimología. El mecanismo de las endopeptidasas serínicas es ilustrativo del gran grupo de enzimas involucradas en la transferencia de fragmentos de sustrato, aunque en este caso la transferencia sea a una molécula de agua. La transferencia intermedia de la porción acilo de un sustrato para formar una unión covalente con un grupo funcional de la enzima es una característica común entre las endopeptidasas serínicas y algunas transferasas (Dunn, 1989).

La fig. 1.2. muestra los grupos esenciales que participan del mecanismo catalítico. El oxígeno del grupo hidroxilo de la serina 195 (los números dados a cada aminoácido corresponden al sistema de numeración de la quimotripsina) ataca al carbonilo de la unión peptídica sensible a través de una reacción catalizada por la histidina 57, que conduce a la formación de un intermediario tetrahédrico y a la transformación de la base imidazol en un ión imidazolio, que inhibe la liberación del protón al solvente. El otro elemento de importancia en la catálisis de la ruptura de la unión peptídica es la presencia de dos grupos imino disponibles (glicina 193 y serina 195) para la formación de puentes de hidrógeno con el anión oxígeno carbonílico generado como consecuencia del ataque nucleofílico (Fersht et al., 1973). El intermediario se descompone por catálisis ácida originando la acil-enzima, liberando la porción "amino" del sustrato. Finalmente, la acil enzima resulta hidrolizada por reversión del mecanismo inicial, donde el hidroxilo del agua actúa como reactivo nucleofílico en lugar del hidroxilo de la serina 195 (Polgar y Halasz, 1982).

La actividad de las proteasas serínicas suele ser máxima a valores de $\mathrm{pH}$ alcalinos y no requiere activadores, pero los iones calcio intervienen en la activación de algunas proenzimas y estabilizarían a algunas de las enzimas.

La especificidad de las endopeptidasas serínicas es extremadamente diversa, pero los subsitios $S$ parecen ser más importantes que los $S^{\prime}$, de lo cual el ejemplo más simple es el de la tripsina, que requiere inevitablemente la ocupación del subsitio $S_{1}$ por una cadena lateral de lisina o arginina del sustrato.

El diisopropilfluorofosfato (DFP) es el inhibidor más útil para la identificación de proteinasas serínicas, ya que tiene acción escasa o nula sobre otro tipo de endopeptidasas, 

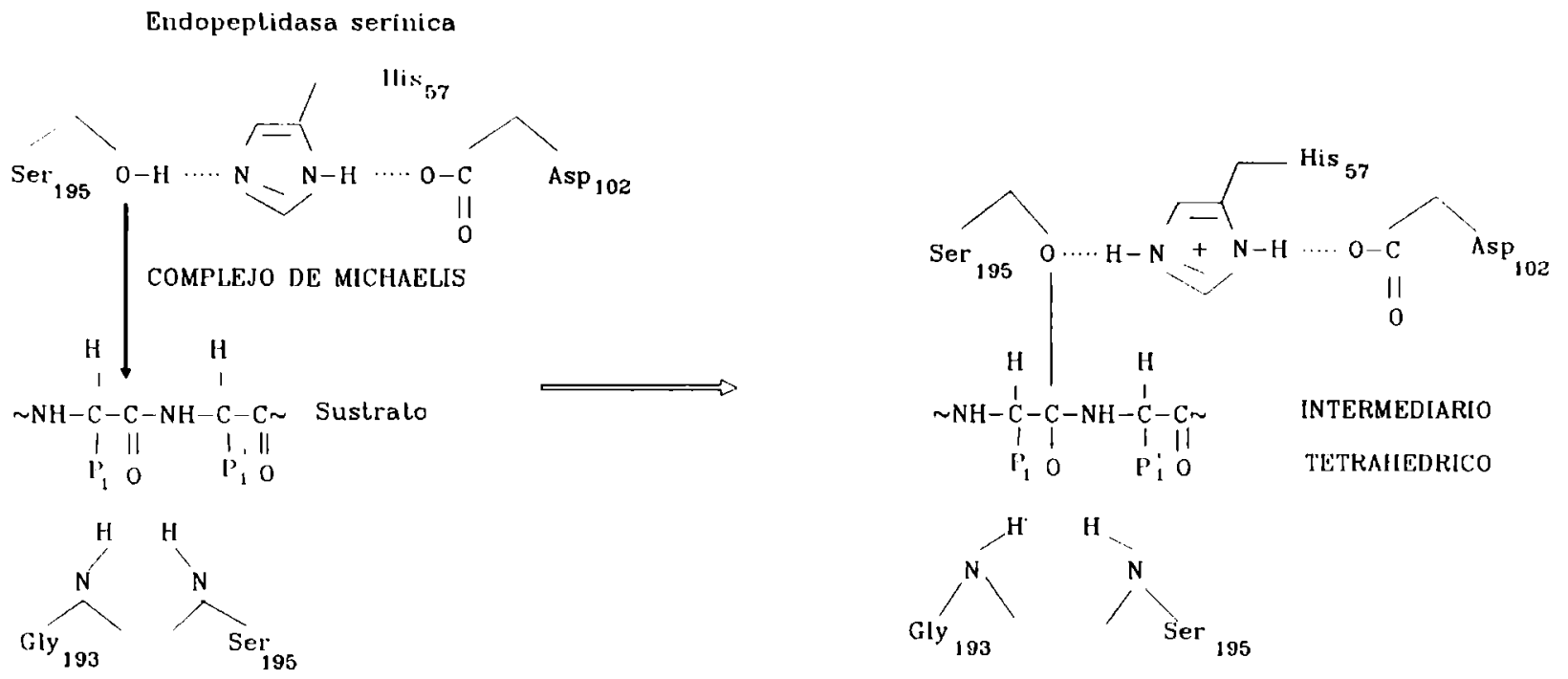

Porción "acilo" del sustrato

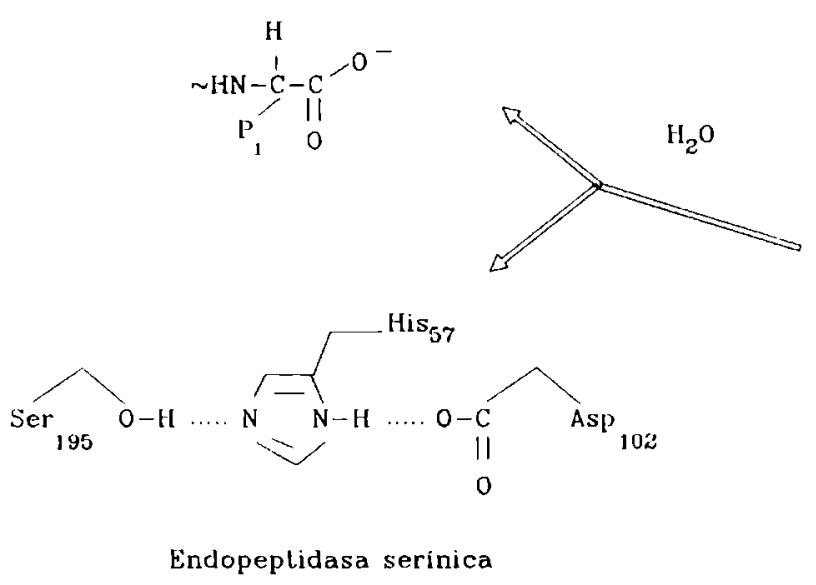

Endopeplidasa serinica

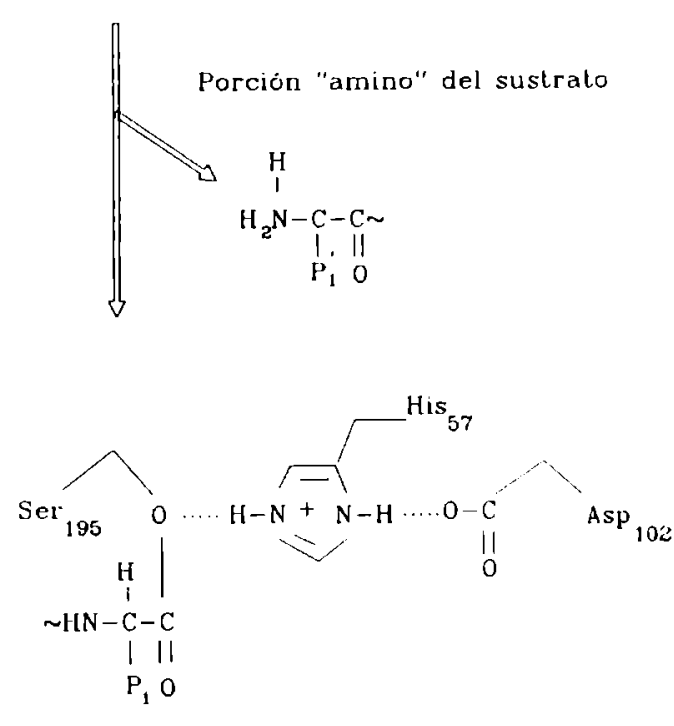

INTERMEDIARIO ACIL-ENZIMA

Fig. 1.2. Representación esquemática de los pasos involucrados en la protéslisis catalizada por una endopeptidasa serínica. $\mathrm{P}_{1}$ y $\mathrm{P}^{\prime}{ }_{1}$ representan las cadenas laterales de los aminoácidos que aportan el grupo carbonilo y anino, respectivamente, de la unión peptídica a escindir (Adaptado de Dunn, 1989). 
pero su acción es irreversible. Se han ensayado, no obstante, inhibidores reversibles naturales y sintéticos, aunque en estos casos la inhibición resulta ser más selectiva (actúan sólo sobre algunos tipos de proteinasas serínicas) y con menor especificidad de grupo, ya que también inhiben proteinasas cisteínicas (Barrett, 1986).

\subsection{Proteinasas cisteínicas}

La sensibilidad de papaína, ficina y bromelina a ser inactivadas por reactivos que bloquean los grupos sulfihidrilo por conversión en puentes disulfuro y su ulterior reactivación por agentes reductores fue lo que llevó a Hartley (1960) a denominarlas "tiolproteinasas". Dado que la cisteína es el único aminoácido que posee un grupo sulfhidrilo (tiol) en la cadena lateral (que en las tres proteinasas citadas corresponde al residuo aminoacídico cisteína 25), se ha recomendado sustituir el término "tiolproteinasas" por el de "proteinasas cisteínicas" (Nomenclature Committee of the International Union of Biochemistry, 1984).

Las proteinasas cisteínicas presentan gran analogía con las anteriores, en razón de la formación de un intermediario covalente (Lowe, 1976). En este caso el nucleófilo es el átomo de azufre de la cadena lateral de la cisteína 25 y también participa una cadena lateral histidina 159 (numeración de papaína) en el rol de aceptor de hidrógeno. La fig. 1.3. muestra un esquema mecanístico simplificado correspondiente a esta familia de enzimas, en la que la participación de dos grupos imino, en este caso correspondientes a glutamina 19 y cisteína 25 (numeración de papaína) actúan como "agujero oxianiónico", en perfecta analogía con las endopeptidasas serínicas.

Las condiciones requeridas para que se manifieste la actividad de las cisteinilproteinasas varía considerablente con la enzima y el tipo de sustrato sobre el que actúan: las ubicadas en los lisosomas lo hacen habitualmente a $\mathrm{pH}$ ácido, en tanto que la papaína tiene un amplio rango de $\mathrm{pH}$ óptimo y las calpaínas son activas a $\mathrm{pH}$ superiores a 7,5. En el caso de las enzimas del tipo de la papaína es habitualmente necesario el agregado de agentes tales como la cisteína o el ditiotreitol y también el de sustancias quelantes, ya que los iones metálicos pueden provocar inhibición, aún en presencia de sustancias reductoras. 
lindopeptirlasa cisteinica (equilibrio tautomérico)
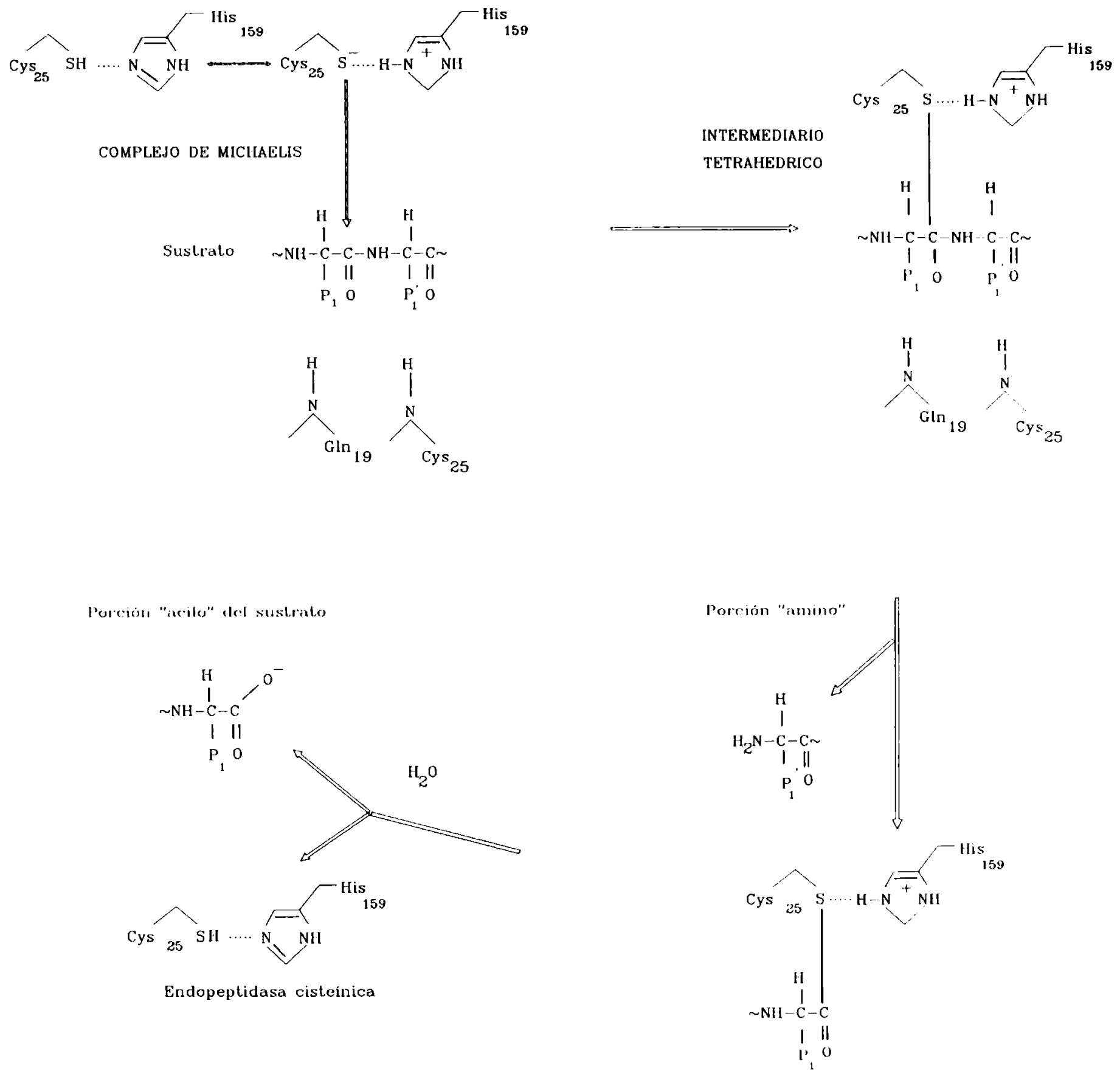

INTERMEDIARIO ACIL ENZIMA

Fig. 1.3. Representación esquemática de los pasos involucrados en la proteólisis de unia proteína por una endopeptidasa cisteínica. El residuo catalítico cisteína 25 se encuentra en equilibrio tautomérico entre la forma neutra y el estado de ion dipolar (zwitterion). El azufre aniónico estaría implicado en el ataque nucleotílico directo sobre el carbonilo de la unión peptídica a escindir (Adaptado de Dum, 1989). 
Los subsitios específicos de papaína han sido relativamente bien establecidos, consignándose 5 a 7 de ellos, de los cuales el más importante parece ser el $S_{2}$, un "bolsillo" hidrofóbico que permite la unión de la cadena lateral de fenilalanina del sustrato (Drenth et al., 1976). La proteinasa estreptocócica tiene también un subsitio $\mathrm{S}_{2}$ que muestra preferencia por la cadena lateral de la fenilalanina (Tai et al., 1976). En contraste, la proteinasa de Clostridium histolyticum es altamente específica para la hidrólisis de uniones peptídicas en las que interviene arginina, tanto en sustratos naturales como sintéticos (Siffert et al., 1976).

La identificación de las proteinasas cisteínicas es sencilla, ya que su actividad se incrementa por el agregado de sustancias reductoras o de reactivos que contengan grupos sulfhidrilo y es inhibida fuertemente por iodoacetato y en menor medida por la $\mathrm{N}$ etilmaleimida, en tanto que los reactivos mercuriales inactivan reversiblemente estas enzimas (Barrett, 1986).

\subsection{Proteinasas aspárticas.}

Hartley (1960) las denominó "proteinasas ácidas", ya que los bajos valores de pH óptimo $(3,0-5,5)$ hacían suponer la participación de grupos carboxilo en el sitio catalítico, presunción luego confirmada por la inactivación de la pepsina por agentes bloqueantes de grupos carboxilo (Fruton, 1976). La denominación de "proteinasas aspárticas" se adoptó luego de comprobarse que en la pepsina de origen porcino los residuos aspártico 32 y aspártico 215 formaban parte del sitio activo (Tang et al., 1973).

Como ya se ha dicho, no existen grupos funcionales de la enzima que lleven adelante un ataque nucleofílico sobre el carbonilo de la unión peptídica a escindir (Hofmann et al., 1984) y por lo tanto no habrá intermediario covalente (fig. 1.4.). El aparato catalítico de estas enzimas consiste en dos cadenas laterales de ácido aspártico. Dado que el grupo carboxilo no es un nucleófilo potente, no puede sorprender que no haya un ataque nucleofílico involucrado en el proceso. Los dos grupos carboxilo se encuentran lo suficientemente cercanos en la estructura terciaria como para compartir un puente de hidrógeno entre los átomos de oxígeno de ambos. La información estructural 


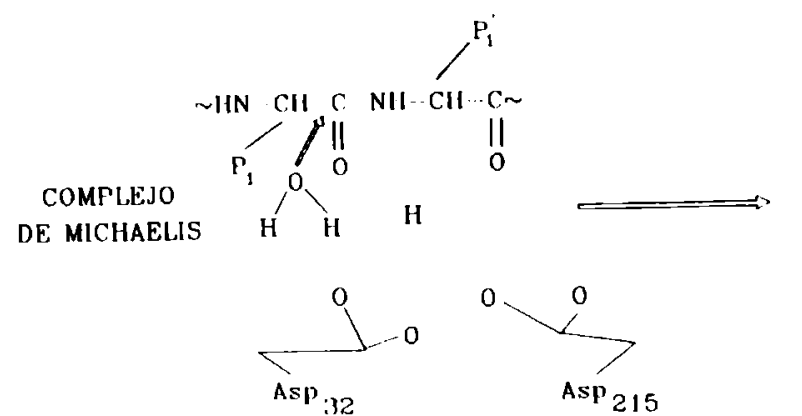

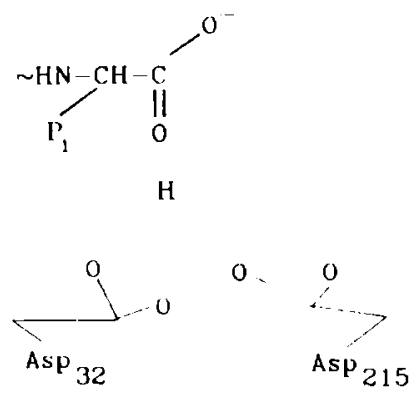

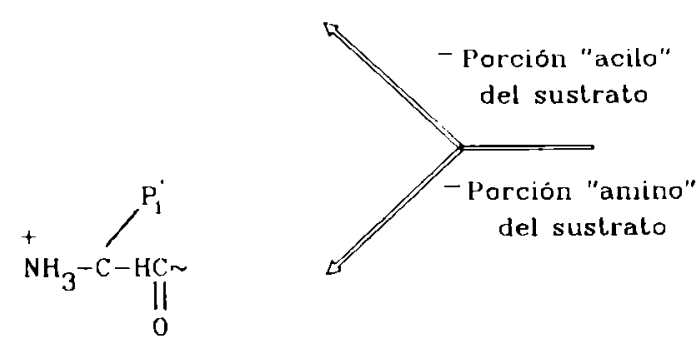

H

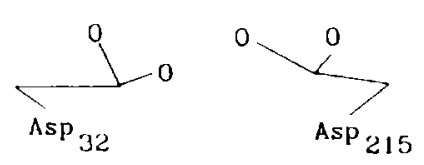

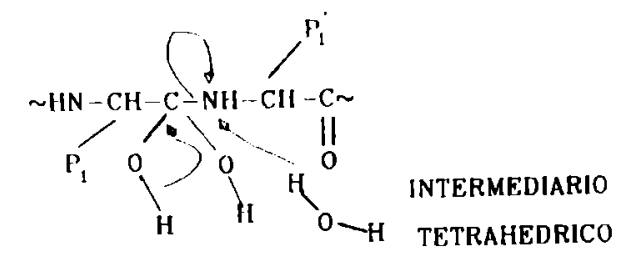

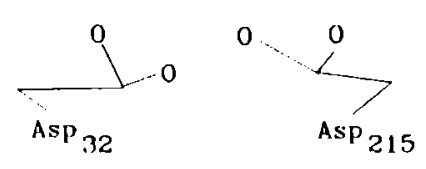

$\sqrt{ }$

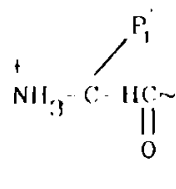

COMPLEJO PRODUCTOS

H

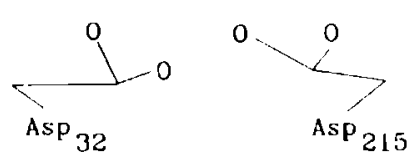

Fig. 1.4. Representación esquemática del mecanismo ácido-base de la proteólisis catalizada por una endopeptidasa aspártica. La ruptura del intermediario tetrahédrico da lugar a un "complejo de producto" conteniendo ambas mitades del sustrato, pudiendo luego originar un complejo acil-producto o amino-producto, como paso intermedio a la liberación final del segundo producto (Adaptado de Dunn, 1989). 
aportada por cristalografía de rayos $\mathrm{X}$ ha confirmado que la ubicación de estas dos cadenas laterales es apropiada para provocar la hidrólisis de la unión peptídica (Pearl, 1987). El mecanismo catalítico implicaría la acción de una molécula de agua sobre el carbonilo sensible, con la mediación de los grupos carboxilato del centro activo en la transferencia de protones (Dunn, 1989).

En general las proteinasas aspárticas actúan mejor sobre uniones peptídicas de aminoácidos con cadenas laterales hidrofóbicas (Leu-Tyr, Tyr-Leu, Phe-Phe, Phe-Tyr, etc.), pero su afinidad por el sustrato varía grandemente. La mayoría de las proteasas aspárticas tienen un amplio rango de especificidad: la pepsina A degrada la mayor parte de las proteínas hasta pequeños péptidos, pero la quimosina coagula la leche por medio de la escisión selectiva de una unión peptídica de la kappa-caseína (Barrett, 1986) y la renina libera angiotensina a través del clivaje de la unión Leu10-Val11 del angiotensinógeno (Green \& Rivetna, 1992).

Las proteinasas aspárticas tienen relativamente pocos inhibidores: el complejo de la diazoacetil-norleucina metiléster con iones cobre inactiva la mayoría de ellas, pero el más efectivo es la pepstatina, un isovalerilpentapéptido de origen microbiano (Umezawa, 1976).

\subsection{Metaloproteinasas}

Este grupo de proteasas que, como las aspárticas, no forman intermediarios covalentes, han encontrado una solución más directa a la necesidad del efecto catalítico sobre el grupo carbonílico de la unión peptídica a hidrolizar: en lugar de depender de un puente de hidrógeno vía un "agujero oxianiónico", las metaloendopeptidasas utilizan la coordinación con un ion metálico para ejercer este efecto. Este metal es usualmente el zinc, aunque en algunas instancias otros metales de transición pueden sustituirlo. Incluso es posible que en un corto tiempo nuevas proteasas de esta clase sean purificadas y demuestren contener otros metales en el sitio activo .

El ion metálico provee un fuerte efecto de "tracción" electrofílica adicional al ataque por una molécula de agua (fig. 1.5.). La enzima nativa tiene una molécula de agua 

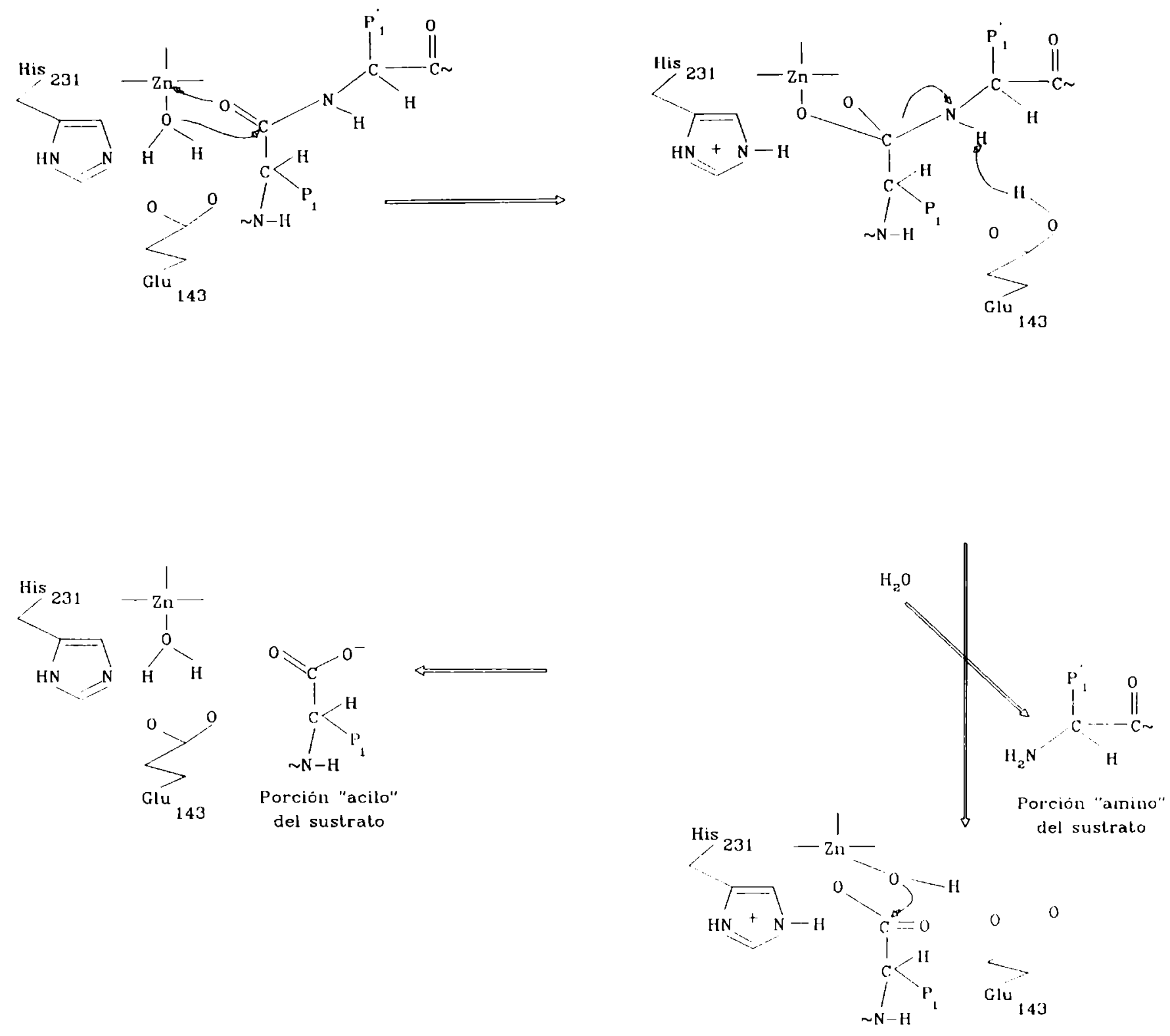

Fig. 1.5. Representación esquenática de la proteólisis catalizada por una metaloendopeptidasa (Adaptado de Dunn, 1989). 
coordinada con la cuarta unión del sitio tetrahédrico (los otros ligandos del metal son dos histidinas y un ácido glutámico en la termolisina), la que está asociada a un residuo de ácido glutámico (glutámico 143 en la termolisina) a través de un puente de hidrógeno. La molécula de agua puede ser desplazada de su unión con el glutámico 143 como consecuencia de la coordinación del grupo carbonilo con el átomo del metal. El carbonilo del ácido glutámico sirve como base para remover un protón de la molécula de agua y apoyar así el ataque nucleofílico del oxígeno sobre el gupo carbonilo de la unión peptídica. Nuevamente, un protón debe ser transferido al grupo amino saliente, que podría provenir del glutámico 143. Así, el ácido glutámico estaría actuando como "lanzadera", análogamente a uno de los grupos catalíticos de las proteinasas aspárticas y a la histidina en las endopeptidasas serínicas y cisteínicas (Dunn, 1989).

La termolisina, aislada de cultivos de Bacilus thermoproteolyticus, es una de las metaloendopeptidasas más estudiadas. La molécula contiene también cuatro sitios para la unión de iones calcio, pero la acción de éstos estaría más relacionada con la estabilidad que con la actividad catalítica (Colman et al., 1972).

Como en las proteinasas aspárticas, dentro de las metaloproteinasas hay una amplia gama en cuanto a especificidad de sustrato y, al igual que aquéllas, tienen preferencia por las uniones peptídicas integradas por aminoácidos con cadenas no polares. Entre los inhibidores figuran, obviamente, los agentes quelantes, en especial los que tienen marcada afinidad por el zinc.

\subsubsection{Evolución de las endopeptidasas}

Hasta hace relativamente poco tiempo parecía haber consenso en que las relaciones evolutivas de las endopeptidasas se acomodaban bien al sistema de clasificación propuesto por Hartley (1960). En consecuencia con ello se postulaba la existencia de una homología evolutiva dentro de cada uno de los cuatro grupos: las proteasas serínicas derivarían de dos líneas ancestrales y las cisteínicas de por lo menos cuatro, en tanto que la situación no era clara en el caso de las metaloproteinasas; por el contrario, las proteinasas aspárticas - 
de origen más reciente- parecerían provenir de un único tronco enzimático primitivo (Dayloff et al., 1983).

El punto de vista actual es mucho menos simple, ya que cada clase contiene enzimas tan diversas que la hipótesis de un ancestro común resulta insostenible (Tabla 1.1.). Como si ello no bastara, han sido secuenciadas y parcialmente caracterizadas varias proteasas de mecanismo catalítico desconocido. En base a la nueva información estructural provista por el conocimiento de la secuencia aminoacídica y de la estructura terciaria de las endopeptidasas parecería que existe un mayor número de líneas evolutivas ("familias de endopeptidasas") y -quizás- más mecanismos catalíticos que los que estábamos dispuestos a asumir hasta ahora (Barrett \& Rawlings, 1991).

\subsection{Proteinasas serínicas.}

El mecanismo de hidrólisis de la unión peptídica serina-dependiente es el que ha evolucionado más exitosamente dentro de las endopeptidasas, a juzgar por el hecho de que las proteasas serínicas son el grupo más diverso y numeroso. Hay dos familias principales de proteinasas serínicas: la familia de la quimotripsina y la familia de la subtilisina.

\subsection{Familia de la quimotripsina}

Las enzimas que integran la familia de la quimotripsina están presentes en microorganismos tanto procarióticos como eucarióticos, así como en plantas, invertebrados y vertebrados. En todos sus miembros es evidente la conservación de la secuencia de aminoácidos alrededor del sitio activo, estando la "tríada catalítica" integrada por histidina 57, aspártico 102 y serina 195 (numeración de quimotripsina).

La estructura de las pequeñas enzimas bacterianas (180 residuos) difiere poco de la que muestran las enzimas de mayor tamaño encontradas en páncreas y en granulocitos de mamíferos: en la mayoría de los animales superiores la evolución se ha manifestado a través del alargamiento del extremo $\mathrm{N}$-terminal para formar "péptidos de activación" (ej. 


\section{Serina}

Quimotripsina. Endopeptidasas A y B de Streptomyces griseus, Endopeptidasa V8 de Staphylococcus, Prolilendopeptidasas $\lg$ A específicas, Endopeptidasa $\alpha$-lítica de Sorangium, Hipodermina C, Endopeptidasa colagenolítica de Uca, Tripsina, Elastasa pancreática, Proteasa E, Granzimas de linfocitos, Quimasa, Triptasa, Catepsina G, Elastasa de leucocitos, Enzimas del complementos, Enzimas coagulantes, Plasnina, Activadores del plasminógeno, Kalikreínas, Trombina, Hepsina, Endopeptidasas serínicas calcio-dependientes, Batroxobina, Flavoxobina

Subtilisina. Termitasa, endopeptidasa K, Endopeptidasa de Vibrio, Endopeptidasa de Yarrowia, Elastasa de Bacillus, Endopeptidasa alcalina de Aspergillus, Endopeptidasa de la envoltura celular de Lactococcus, Cucunisina, Endopeptidasa B de levadura, Kesina, Furina, PC1, PC2

\section{Prolilendopeptidasa}

Complejo multicatalítico endopeptidasico

Endopeptidasas de Adenovirus

Proteasa IV de E. coli

Proteasa VII de E. coli, Coagulasa de Yersinia, Activador de Salmonella

\section{Endopeptidasa Ti}

\section{Endopeptidasa La}

\section{Cisteína}

Papaina, Actinidina, Quimopapaína, Endopeptidasas de papaya III y IV. Ficina, Bromelinas, Aleuraína, Calotropina, Endopeptidasas cisteínicas de tomate, soja, poroto nung, Tripanosoma, Haemonchus Schistosoma, Dictyostelium, polvo ambiental, Catepsinas B, H, L y $\mathrm{S}$

\section{Calpainas}

\section{Endopeptidasa cistelnica de estreptococo}

\section{Clostripaina}

Endopeptidasas de Picornavirus, Endopeptidasas de virus de poliomielitis, encéfalomiocarditis, calicivirus felino, virus vegetales similares

Tabla 1. Familias y tipos de endopeptidasas (Barrett y Rawlings, 1991; Jiang y Bond, 1992) 
Tipo catalítico Familia (miembro representativo, otros miembros)

Aspártico

Pepsina, Gastricina, Quimosina, Renina, Catepsinas D y E, Pepsinas de Penicillium, Rhizopus, Endothia, Aspergillus

Proteasa B de Scytalidium

Endopeptidasa del Virus de Inmunodeficiencia Humana (HIV), Endopeptidasas de virus de leucemia, de vinus del sarcoma de Rous, de retrovirus de simios

Thermopsina

Metal

Thermolisina, Bacillolisina, Elastasa de Pscudomonas

Astacina

Metaloendopeptidasa de Serratia, Proteasas B y C de Erwinia

Matrixina, Colagenasa intersticial, Colagenasas microbianas, Colagenasa neutrófila, Gelatinasas A y B, Stromelisina,

Metalo-endopeptidasas de veneno de serpiente

Metalo-endopeptidasa ß-lútica

Insulinasa. Endopeptidasa Pi, Peptidasas procesadoras mitocondriales

Desconocido

Peptidasa-guía bacteriana I

Peptidasas-gulas de lipoproteinas bacterianas

Peptidasas-guías de eucariotes

Proteasa pro-cabeza de bacteribfago T4

Tabla 1. Familias y tipos de endopeptidasas (continuación) 
tripsinógeno), que requieren ser removidos para generar la proteinasa activa (tripsina, en el mencionado caso).

\subsection{Familia de la subtilisina}

Los miembros de esta familia de endopeptidasas serínicas se caracterizan por conservar la secuencia de aminoácidos alrededor de los residuos catalíticos: aspártico 32, histidina 64 y serina 221 (numeración de subtilisina). Si bien éstos son los mismos aminoácidos que encontramos en la quimotripsina y la estructura terciaria está dispuesta con una geometría similar, la secuencia de la cadena polipeptídica es diferente y muestran un patrón de plegamiento totalmente distinto, por lo que no existen dudas de que las familias de la quimotripsina y de la subtilisina han tenido orígenes distintos $y$ han evolucionado convergentemente para lograr sitios catalíticos similares.

Si bien en un principio se creyó que las enzimas de la familia de la subtilisina estaban confinadas a bacterias, actualmente han sido encontradas ampliamente distribuidas en otros microorganismos, en plantas y aún en animales superiores. Las subtilisinas bacterianas típicas no contienen cisteína, mientras que la termitasa de Thermoactinomyces vulgaris contiene un residuo de cisteína cerca de la histidina del centro catalítico, el que es retenido en la mayoría de los homólogos eucarióticos, como la proteinasa $\mathrm{K}$ y la proteinasa B de levaduras (Moehle et al., 1987). Aunque este grupo tiol está enterrado en la molécula nativa puede reaccionar con algunos reactivos tiol-específicos, por lo que estas enzimas también pueden ser inhibidas por inhibidores de proteasas cisteínicas (Betzel et al, 1990).

Una función particularmente significativa de los homólogos de la subtilisina -que ha sido recientemente descubierta en organismos que van desde levaduras hasta seres humanos- es el procesamiento de precursores de proteínas por clivaje de residuos básicos vecinos, como ocurre en numerosas proteínas de mamíferos, incluídas la insulina y las hormonas relacionadas con la hormona adrenocorticotrófica (ACTH). 


\subsection{Otras endopeptidasas serínicas}

No todas las endopeptidasas serínicas conocidas pueden ser incluídas en alguna de las dos familias antes mencionadas. Un caso típico es el de la prolil-endopeptidasa, cuya presencia se extiende desde flavobacterias hasta mamíferos y que es responsable de la hidrólisis de uniones peptídicas que contienen prolina (Rennex et al., 1991).

Otro ejemplo es el del complejo multicatalítico endopeptidásico, complejo proteolítico de elevada masa molecular relativa que abunda en hígado y otros tejidos de animales superiores, aunque también ha sido hallado en hongos. La molécula está compuesta por un gran número de subunidades de $21-32 \mathrm{kD}$ y parece contener tres sitios activos serínicos separados. La secuencia de las subunidades, si bien aún no está completa, no ha mostrado homología con otras peptidasas (Rivett, 1989).

Las endopeptidasas de adenovirus son enzimas procesadoras involucradas en la maduración del virión, que hidrolizan específicamente uniones Gly-Ala en cinco proteínas precursoras codificadas por el DNA viral. Son inhibidas por DFP y algunos otros inhibidores de proteasas serínicas, pero sin embargo su secuencia no se relaciona con otras proteasas serínicas conocidas (Houde \& Weber, 1990).

La bacteria Escherichia coli es fuente de una serie de endopeptidasas serínicas atípicas. La proteasa IV muestra especificidad hidrolítica por el lado carboxílico de los residuos hidrofóbicos y es responsable de la degradación de péptidos guía (Dev \& Ray, 1990). La proteasa VII (que al igual que la anterior está asociada a membranas) actúa sobre uniones peptídicas constituidas por residuos básicos (Sugimura \& Nishihara, 1988). La endopeptidasa Ti (también llamada Clp) y la endopeptidasa La son ATP-dependientes. pero esta última es también inactivada por inhibidores cisteínicos (Woo et al., 1989).

\subsection{Proteinasas cisteínicas}

La mayoría de las endopeptidasas de esta clase están incluidas dentro de la familia de la papaína. El resto de ellas forma parte de la familia de las calpaínas, a excepción de unos pocos grupos especializados que parecen haber tenido un origen independiente. 


\subsection{Familia de la papaína}

La proteinasa cisteínica más estudiada es la papaína, obtenida a partir del látex de Carica papaya, que encabeza la familia cisteínica de mayor distribución y a la que pertenecen las endopeptidasas cisteínicas vegetales, así como las catepsinas lisosomales $\mathrm{B}$, $\mathrm{H}, \mathrm{L}$ y $\mathrm{S}$. Todas ellas conservan la estructura aminoacídica vecina a los residuos cisteína 25 e histidina 159 (numeración de papaína), que están directamente involucrados en el proceso proteolítico.

Muchos protozoos contienen endopeptidasas semejantes a la papaína (North, 1982), habiéndose postulado que los ancestros enzimáticos del grupo estuvieron localizados en las vacuolas digestivas de un protozoario primitivo. La línea evolutiva que -mediante la adquisición de plástidos fotosintéticos- dio origen a los primeros vegetales conservó las proteasas en el interior de dichas vacuolas, que en muchas plantas vasculares formaron luego parte del látex. En el caso de los animales, las primitivas vacuolas digestivas derivaron en los actuales lisosomas (Barrett, 1986).

\subsection{Familia de las calpaínas}

La unidad funcional de las endopeptidas cisteínicas de la familia de la papaína parece haber sido tomada como modelo por el proceso de evolución para construir las moléculas más sofisticadas que integran la familia de las calpaínas, endopeptidasas calciodependientes de amplia distribución en vertebrados e invertebrados y que poseen una estructura molecular altamente conservativa, compuesta de dos subunidades de 30 y 80 kD. Los segmentos C-terminales de ambas subunidades contienen sitios específicos para la unión de los iones calcio. Hacia el extremo $\mathrm{N}$-terminal de la subunidad mayor se encuentra el segmento responsable de la actividad proteolítica de la molécula, que contiene residuos de histidina y cisteína en secuencia similar a la de la papaína (Ohno et al., 1984). 


\subsection{Otras endopeptidasas cisteínicas}

Existen endopeptidasas cisteínicas en bacterias, pero su estructura es tan diferente de la que exhiben papaína y sus homólogos que no hay elementos para suponer que provengan de un ancestro común. Tal es el caso de una proteinasa estreptocócica que -al igual que papaína- posee un subsitio $\mathrm{S}_{2}$ con fuerte preferencia por unirse a la cadena lateral de fenilalanina (Kortt \& Liu, 1973); sin embargo su secuencia aminoacídica es totalmente diferente a la de aquélla (Yonaha et al., 1982)

La clostripaína, endoproteasa aislada de Clostridium histolyticum, es altamente específica para la hidrólisis de sustratos con un residuo arginina en $\mathrm{P}_{1}$ (Siffert et al., 1976) y es activada por calcio, pero la secuencia aminoacídica alrededor del residuo esencial de cisteína es totalmente diferente a la de otras cisteinil-proteasas (Gilles et al., 1983).

Los picornavirus y el virus de la poliomielitis contienen endopeptidasas que parecen ser de tipo cisteínico. Sin embargo, el análisis detallado de la secuencia de algunos de los genes virales ha revelado similitudes con endopeptidasas serínicas bacterianas (Bazan \& Fletterick, 1988). Este sería a la fecha el único ejemplo de relaciones evolutivas que cruzan el límite entre las distintas clases de endopeptidasas, aún cuando Brenner (1988) ha sugerido que todas las enzimas de la familia de la quimotripsina provienen esencialmente de endopeptidasas cisteínicas que evolucionaron en dos líneas separadas.

\subsection{Proteinasas aspárticas}

La mayoría de las proteasas aspárticas son enzimas de cadena simple con un peso molecular de aproximadamente 35.000 (40.000 para las proenzimas). La pepsina porcina fue la primera en ser secuenciada y hasta ahora existen datos de las secuencias totales o parciales de más de cien proteasas aspárticas, habiéndose encontrado una notable similitud en las secuencias que incluyen a los dos residuos de ácido aspártico que integran el sitio activo (Szecsi, 1992). 
En las endopeptidasas de mamíferos y las de hongos tales como Penicillium, Rhizopus y Endothia pertenecientes a la familia de la pepsina, las moléculas están formadas por dos lóbulos con el sitio activo en el medio de ellos. Los dos residuos directamente responsables de la actividad catalítica (aspártico 32 y aspártico 215, numeración de pepsina), están localizados en segmentos polipeptídicos que son sorprendentemente similares, lo que llevó al descubrimiento de que los dos lóbulos son homólogos, es decir que la molécula es el resultado de la duplicación de un gen (Tang et al., 1978). Dentro de cada lóbulo puede ser vista otra doble simetría en el polipéptido plegado, aunque estas similitudes son menos obvias (Blundell et al., 1979).

Actualmente han sido comunicadas las estructuras cristalinas de alta resolución para más de una docena de proteasas aspárticas. La estructura secundaria consiste casi enteramente en hoja plegada beta, con muy pocas y pequeñas zonas de alfa hélice (Davies, 1990; James \& Sielecki, 1987).

El basidiomicete Scytalidium lignorum produce una endopeptidasa ácida (proteasa B) que -a diferencia de la pepsina- no es inhibida por pepstatina. Se trata de una proteína pequeña $(20 \mathrm{kD})$, que parece ser activa únicamente en forma dimérica, al igual que las endopeptidasas del virus de inmunodeficiencia humana (HIV) y en la que el residuo aspártico del sitio activo habría sido reemplazado por el ácido glutámico (Tsuru et al., 1986).

También han sido encontradas endopeptidasas aspárticas no inhibibles por pepstatina en bacterias pertenecientes a los géneros Pseudomonas y Xanthomonas (Oda et al., 1987).

Otra endopeptidasa aspártica de origen bacteriano es la thermopsina, cuya secuencia de aminoácidos no guarda ninguna relación evolutiva con otras enzimas conocidas y sería más bien el producto de un evento evolutivo independiente (Fusek et al., 1990). 


\subsection{Metaloproteinasas}

Es probable que el zinc sea el metal catalíticamente activo en las formas naturales de todas estas endopeptidasas, aunque algunas de ellas retienen la actividad cuando se lo reemplaza por otro metal como el cobalto (Barrett, 1991).

La más estudiada de las metaloproteinasas es la termolisina del Bacillus thermoproteolyticus, cuyo sitio activo contiene tres residuos aminoacídicos que actúan como ligandos y una molécula de agua enlazada a un átomo de zinc. Los dos primeros ligandos son dos residuos de histidina ubicados dentro de la secuencia HEXXH (His-GluXaa-Xaa-His), en la cual el ácido glutámico actuaría como base catalítica, en tanto que el tercer ligando es un ácido glutámico remoto, situado 20 lugares más adelante (hacia el extremo C-terminal) a partir del segundo residuo de histidina (Matthews, 1988).

El grado de conservación de la secuencia HEXXH -involucrada en la unión con el átomo de zinc- es notable, ya que se encuentra en casi todas las familias que han sido caracterizadas, pero además está presente en exopeptidasas (metaloaminopeptidasas), por lo que una secuencia tan corta pudo fácilmente haber evolucionado independientemente por convergencia para cumplir estrictos requerimientos funcionales.

La información actualmente disponible de la estructura primaria de diferentes metaloproteinasas ha hecho posible comparar las secuencias aminoacídicas correspondientes a los sitios de unión al zinc, lo que ha permitido a Jiang \& Bond (1992) proponer un atractivo esquema de clasificación. Sobre la base de los dos primeros ligandos del zinc las metaloendoproteinasas pueden ser divididas en dos categorías principales, una con la secuencia HEXXH y otra con la secuencia HXXEH. A este último grupo pertenecen una metaloproteinasa B-lítica aislada de especies de Achromobacter y Enzymogenes (Li et al., 1990) y la insulinasa, una proteasa citoplasmática encontrada en Drosophila y en células de animales superiores (Kuo et al., 1990).

La mayoría de estas endopeptidasas pertenecen a la primera categoría. La identidad del tercer ligando (ácido glutámico o histidina) permite dividir a las metaloproteinasas HEXXH en otros dos grupos, siendo la familia de la termolisina un ejemplo típico de las enzimas que contienen ácido glutámico como tercer ligando. Las del segundo grupo contienen una histidina como tercer ligando del zinc y como ligando adicional a un 
residuo de tirosina. Sobre la base del residuo aminoacídico ubicado inmediatamente después de la histidina y en menor grado por la homología presente en las secuencias que contienen a la tirosina, este grupo puede a su vez subdividirse en cuatro familias: a) la familia de la astacina contiene ácido glutámico y la secuencia SIMHY, b) la familia de la proteasa de Serratia contiene prolina y la secuencia SIMSY, c) la familia de la matrixina contiene serina y la secuencia IQSLY y d) la familia de las metaloproteinasas de venenos de víbora contiene ácido aspártico y la secuencia SKXYY.

Se ha comprobado una homología significativa dentro de los miembros de una misma familia y no así entre los miembros de familias distintas, hecho que corrobora la clasificación propuesta por Jiang \& Bond (1992).

\subsection{Proteinasas de mecanismo catalítico desconocido}

Existe un buen número de endopeptidasas que no admiten ser ubicadas en ninguna de las cuatro categorías anteriores. Este hecho había sido sostenido desde hace un tiempo en base a estudios de inhibición, pero la disponibilidad de la información sobre la secuencia aminoacídica de las mismas coloca ahora el asunto fuera de toda discusión.

Escherichia coli posee dos peptidasas guía (o señal), ambas transmembránicas. La peptidasa-guía I , que actúa en el procesamiento de la mayoría de las proteínas secretadas, posee una secuencia aminoacídica que no muestra homología con ninguna de las conocidas. La peptidasa-guía II (prolipoproteína-guía peptidasa) hidroliza la pre-secuencia de la lipoproteína mureína, el componente principal de la membrana de $E$. coli; su secuencia aminoacídica, así como las de las proteasas equivalentes de especies de Pseudomonas y Enterobacter, no muestra correspondencia con la secuencia de la peptidasa-guía I ni con la de ninguna otra endopeptidasa conocida. A diferencia de las peptidasas-guía de origen bacteriano, las de eucariotes consisten de al menos dos subunidades, una de ellas glicosilada. Las subunidades secuenciadas hasta el momento no muestran homologías con las correspondientes a sus pares bacterianos (Dev \& Ray, 1990). 
Finalmente, otra enzima procesadora de interés es la endopeptidasa pro-cabeza del bacteriófago T4, responsable de la maduración de casi todas las proteínas pro-cabeza del bacteriófago por hidrólisis proteolítica, usualmente en uniones Glu-Ala. La proteasa no resulta inactivada por inhibidores de proteinasas serínicas ni cisteínicas y la secuencia aminoacídica no guarda relación con ninguna de las ya conocidas (Keller \& Bickle, 1986).

\subsubsection{Peptidasas o exopeptidasas}

En tanto que las endopeptidasas son casi siempre moléculas monoméricas de bajo peso molecular, muchas exopeptidasas están integradas por dos o más subunidades, con pesos moleculares relativos $\left(\mathrm{M}_{\mathrm{r}}\right)$ de varios cientos de miles. Una buena parte de ellas son metalo-enzimas con una fracción glucosídica asociada y en general son menos estables que las proteinasas (McDonald, 1985).

Los diferentes tipos de exopeptidasas están esquematizados en la fig. 1.6. Para clasificarlas se tienen en cuenta el tamaño del sustrato (esto permite separar a las di- y tripeptidasas del resto), la identidad del extremo atacable (N- o C-terminal), el estado de este último (bloqueado en el caso de las omega-peptidasas) y la magnitud del fragmento escindido (aminoácido, dipéptido o tripéptido terminales).

En razón de que las exopeptidasas se agrupan de acuerdo a características de especificidad y no de mecanismo de acción, las enzimas ubicadas dentro del mismo grupo no son necesariamente homólogas y las similitudes en especificidad sólo pueden explicarse en términos de convergencia, desde el punto de vista evolutivo (Barrett, 1986).

\subsubsection{Aminopeptidasas o aminoacil peptidasas.}

Son también llamadas $\alpha$-aminoacilpéptido-hidrolasas, pues muestran preferencia por separar el aminoácido $\mathrm{N}$-terminal del péptido. La mayoría de las aminopeptidasas reconocen al aminoácido terminal, pero en algunos casos la enzima reconoce al aminoácido subterminal. Así el nombre "prolil-aminopeptidasa" describe una exopeptidasa 

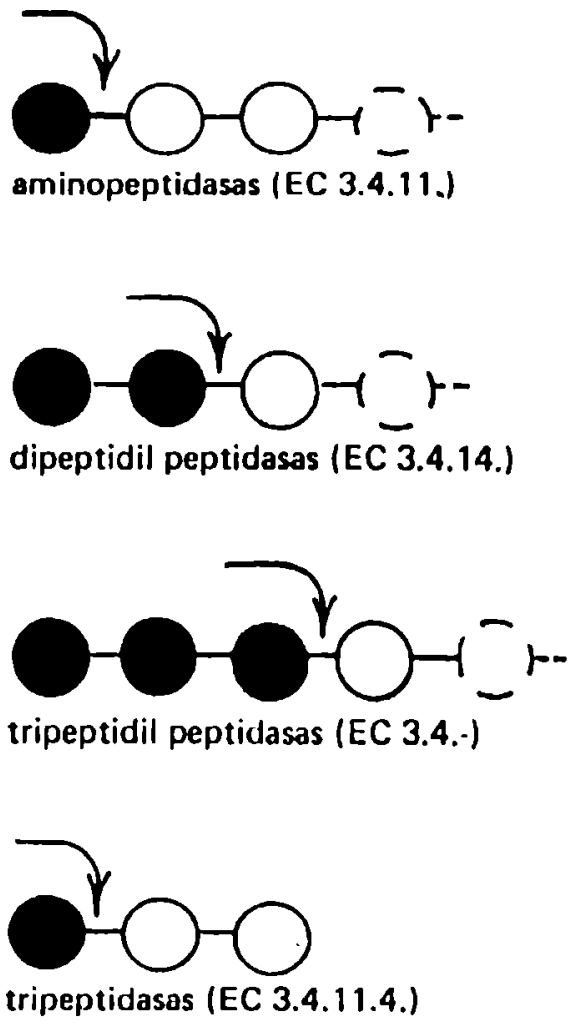
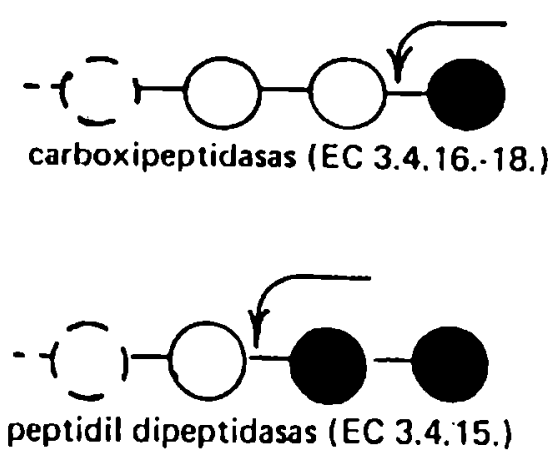
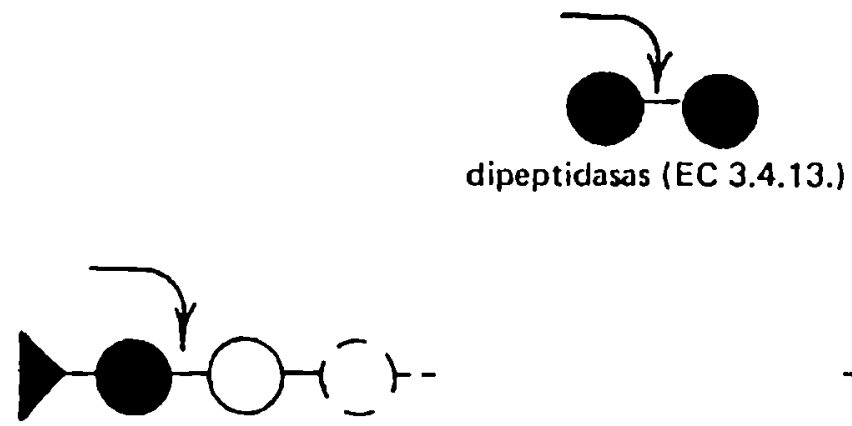

dipeptidasas (EC 3.4.13.)

omega peptidasas (EC 3.4.19.)

Figura 1.6. Tipos de exopeptidasas. Los círculos llenos representan los fragmentos liberados (adaptado de Barrett, 1986) 
que requiere (o al menos prefiere) sustratos en los que prolina es el aminoácido $\mathrm{N}$ terminal, en tanto que la denominación "prolina-aminopeptidasa" se aplica a una enzima que libera cualquier aminoácido $\mathrm{N}$-terminal, siempre que esté unido a prolina (McDonald, 1985).

\subsubsection{Dipeptidil y tripeptidil peptidasas.}

Hidrolizan la unión formada entre el grupo carboxilo de un di- o tripéptido y el grupo amino de un polipéptido (de allí el nombre), liberando dipéptidos o tripéptidos desde el extremo N-terminal, en la mayoría de los casos en forma secuencial, por lo que los sustratos resultan altamente degradados.

\subsubsection{Carboxipeptidasas.}

Son responsables de la liberación de los aminoácidos C-terminales de las cadenas polipeptídicas. Al igual que las aminopeptidasas, pueden reconocer el aminoácido terminal o subterminal. A pesar de que las exopeptidasas no se clasifican en base a su mecanismo de acción, se han previsto códigos separados para las carboxipeptidasas serínicas (EC 3.4.16), las metalocarboxipeptidasas (EC 3.4.17.) y las carboxipeptidasas cisteínicas (EC 3.4.18), dado el conocimiento que se posee del mecanismo catalítico de muchas de ellas (Nomenclature Committee of the International Union of Biochemistry, 1984).

\subsubsection{Peptidil dipeptidasas.}

Estas enzimas atacan la unión peptídica establecida entre el grupo carboxilo terminal de un polipéptido y el grupo amino terminal de un dipéptido, es decir que separan un dipéptido a partir del extremo C-terminal de la cadena polipeptídica. 


\subsubsection{Dipeptidasas y tripeptidasas.}

Actúan sobre di- o tripéptidos. Se conocen muchas dipeptidasas que exhiben especificidad absoluta (deben reconocer los dos aminoácidos) o parcial (solamente uno de ellos). Las tripeptidasas se comportan usualmente como tripéptido-aminopeptidasas, liberando el aminoácido $\mathrm{N}$-terminal de muchos tripéptidos, pero en algunos casos pueden actuar como tripéptido-carboxipeptidasas (McDonald, 1985).

\subsubsection{Omega peptidasas.}

Se incluyen dentro de este grupo a un conjunto de enzimas que actúan sobre los extremos de sustratos en los que el grupo amino o carboxilo terminal está bloqueado o donde la unión no es $\alpha$-peptídica (casos en los que la unión peptídica terminal involucra al grupo omega-carboxilo de los ácidos glutámico o aspártico o al grupo epsilon-amino de lisina).

\subsection{Proteasas de látex}

La gran importancia de las proteasas en los vegetales superiores deriva del hecho de que la hidrólisis de las proteínas y la reutilización de sus aminoácidos constitutivos es fundamental para todos los procesos de desarrollo: a) en la germinación las proteínas de reserva son movilizadas para permitir la construcción de las proteínas que requiere la plántula, b) durante el crecimiento y diferenciación el recambio de las proteínas existentes y su reemplazo por otras nuevas constituye la clave para la adaptación al medio ambiente y c) en los procesos de senescencia las proteínas son degradadas y los aminoácidos transportados y almacenados para ser posteriormente reutilizados en la construcción de otras proteínas (Boller, 1986).

Resulta sorprendente, entonces, que las proteasas vegetales primero descubiertas, más estudiadas y mejor caracterizadas no tengan función aparente en el crecimiento y 
desarrollo. Papaína (EC 3.4.22.2), la principal proteinasa del látex de frutos del "mamón" o "papaya", se encuentra en una concentración tal que excede al menos en dos órdenes de magnitud cualquier potencial necesidad de recambio de las proteínas del fruto (Glazer \& Smith, 1971). Lo propio ocurre con ficina (EC 3.4.22.3), presente en el látex de higos, y con bromelina (EC 3.4.22.4), obtenida de tallos de ananá, a las que por ello se las ha denominado "proteínas prescindibles" (Adams \& Rinne, 1981). Por analogía con los metabolitos secundarios, Boller (1986) considera a estas "proteasas abundantes" como "proteínas secundarias", que estarían destinadas a interactuar con otras especies vegetales o animales con funciones de protección o de defensa (aleloquímicos).

\subsubsection{Proteasas de Asclepiadaceae}

Del látex de Asclepias speciosa Winnick et al. (1940) aislaron una proteinasa sulfhidrílica a la que denominaron asclepaína "s" y simultáneamente Greenberg \& Winnick (1940) obtuvieron una enzima de iguales características a partir del látex de Asclepias mexicana (asclepaína "m"), ambas con máxima actividad a $\mathrm{pH} 7,5$ frente a hemoglobina desnaturalizada y ovalbúmina.

Poco tiempo después Carpenter \& Lovelace (1943) determinan que el pl de una proteasa aislada de Asclepias syriaca es de 3,1. El látex de esta especie fue sometido a posteriores estudios (Brockbank \& Lynn, 1979; Lynn et al., 1980), que revelaron la existencia de al menos dos tipos de proteasas, cada una de ellas con múltiples formas que difieren ligeramente en su composición de aminoácidos, su pH óptimo $(7$ a 8,5$)$ y su peso molecular (21 y $23 \mathrm{kD})$, aún cuando su comportamiento frente a la cadena B de insulina muestra una especificidad esencialmente similar.

Más recientemente (Barragán et al., 1985; Tablero et al., 1991) se han estudiado las distintas formas moleculares de proteasas presentes en el látex de Asclepias glaucescens, que no difieren significativamente de las presentes en las anteriores especies: si bien el pI varía de 3,6 a 9,2, las proteasas más abundantes (de pl superior a 9) tienen un peso molecular de $23 \mathrm{kD}$ y su estructura secundaria es muy similar a la de papaína. 
Del látex de Calotropis gigantea se aislaron inicialmente dos cisteinilproteasas (Abraham \& Joshi, 1979a, 1979b), denominadas calotropina FI y calotropina FII; se trata de glicoproteínas de parecido peso molecular (23-27 kD) que muestran dos valores óptimos de $\mathrm{pH}$ sobre hemoglobina $(4,3$ y 8,1$)$ y similar composición aminoacídica. Un estudio posterior ( $\mathrm{Pal} \&$ Sinha, 1980) reveló la existencia de dos proteinasas adicionales (calotropinas DI y DII) que pudieron cristalizarse y que poseen un único máximo de

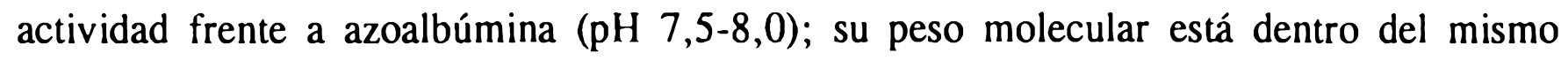
rango $(24 \mathrm{kD})$ pero su composición aminoacídica difiere cuantitativamente de las anteriores.

\subsubsection{Proteasas de Caricaceae}

Las proteasas del látex de "mamón" o "papaya" (Carica papaya L., Caricaceae) han sido las más extensamente estudiadas (Kimmel \& Smith, 1957; Glazer \& Smith, 1971; Arnon, 1970; Brocklehurst \& Salih, 1983). El látex contiene al menos cuatro proteasas mayoritarias que representan cerca del $50 \%$ del total de las proteínas del mismo (Robinson, 1975; Brocklehurst \& Salih, 1983). Todas son proteasas cisteínicas con propiedades enzimáticas similares, pero claramente distinguibles por sus actividades relativas frente a distintos sustratos (Glazer \& Smith, 1971), por su reactividad con ciertos reactivos sulfhidrílicos (Baines \& Brocklehurst, 1982) y por su basicidad (Brocklehurst \& Salih, 1983).

Papaína, un constituyente mas bien menor del látex de frutos de papaya (Robinson, 1975) puede ser fácilmente cristalizada y está muy bien caracterizada bioquímica (Kimmel \& Smith, 1957; Glazer \& Smith, 1971; Arnon, 1970; Syu et al., 1983) y biofísicamente (Ramshaw, 1982). Se trata de una de las enzimas vegetales más estudiadas: su secuencia de aminoácidos está documentada (Hussain \& Lowe, 1970b), se ha determinado su estructura cristalina con una resolución de $1,65 \AA$ (Kamphuis et al., 1984), su mecanismo enzimático ha sido extensamente analizado (Brocklehurst et al., 1981) y se ha estudiado el efecto de modificaciones químicas de la enzima sobre varios parámetros cinéticos (Glick \& Brubacher, 1977). El DNA que codifica a la papaína ha sido clonado y secuenciado por 
Cohen et al. (1986), logrando posteriormente su expresión en Escherichia coli (Cohen et al., 1990) y también en Saccharomyces cerevisiae (Vernet et al., 1993).

La separación y caracterización de las otras enzimas proteolíticas (quimopapaína y papaya peptidasas) parece ser más dificultosa (Kunimitsu \& Yasunobu, 1970; Brocklehurst \& Salih, 1983). En la mayoría de los estudios bioquímicos se emplea látex de papaya seco, comercialmente procesado, o subfracciones comerciales de este producto más que el látex fresco, lo que torna difícil verificar la significancia de las variantes enzimáticas descriptas (Khan \& Polgar, 1983), por lo que no puede asegurarse si realmente se encuentran en el vegetal o si son un producto del procesamiento. La secuencia $\mathrm{N}$-terminal de las cuatro proteasas muestra una alta homología, indicando una familia de genes estrechamente relacionados (Lynn \& Yaguchi, 1979). La opinión de Barret \& Buttle (1985) es que el grupo de la quimopapaína debería ser considerado como una enzima única con múltiples formas cromatográficas, pero para Brocklehurst et al. (1985) se trata de dos proteinasas distintas, a las que denominan quimopapaína A y B.

Goodenough \& Owen (1987), utilizando cromatografía rápida (FPLC) de intercambio aniónico acompañada por electroforesis en geles ácidos de poliacrilamida logran separar cinco proteinasas. De acuerdo a estos autores, según sus valores de $\mathrm{pl}$ y $\mathrm{Mr}$ las enzimas proteolíticas de papaya pueden ser clasificadas en: papaína $(\mathrm{pl}=8,75 ; \mathrm{Mr}=$ 23.000), quimopapaína $\mathrm{A}(\mathrm{pl}=10,3-10,4 ; \mathrm{Mr}=24.000)$, quimopapaína $\mathrm{B}(\mathrm{pl}=10,6$ $10,7 ; \mathrm{Mr}=24.000)$, papaya proteinasa $\mathrm{A}($ omega $)(\mathrm{pl}=11,0 ; \mathrm{Mr}=24.000)$ у papaya proteinasa $\beta(\mathrm{pI}=11,0 ; \mathrm{Mr}=28.000)$. La proteinasa omega ha sido cristalizada, se ha resuelto su estructura tridimensional (Pickersgill et al., 1991) y recientemente se ha reportado la secuencia nucleotídica de su cDNA y su expresión en Escherichia coli (Revell et al., 1993).

A partir del látex de frutos inmaduros de Carica candamarcensis Hook, especie que crece espontáneamente en el Zaire, se han separado por cromatografía de intercambio catiónico a pH 5,0 cuatro fracciones proteolíticamente activas (CC-I a CC-IV), que fueron caracterizadas por elecroforesis ácida en geles de poliacrilamida, análisis del espectro infrarrojo por transformada de Fourier y estudios preliminares de especificidad, así como por determinación de las secuencias aminoacídicas $\mathrm{N}$-terminales hasta la posición 43 . Las 
fracciones CC-I y CC-III serían equivalentes a papaína y quimopapaína (Walreavens et al., 1993).

En el látex de Pileus mexicanus ("cuaguayote") Castañeda-Agulló et al. (1942) hallaron una enzima proteolítica muy activa, a la que denominaron mexicaína, que luego pudieron obtener en forma cristalina por enfriamiento del látex diluido a $\mathrm{pH} 5,5$ (Castañeda-Agulló et al., 1945) y que no requería cianuro ni cisteína para poner de manifiesto su actividad. No obstante, años más tarde se comprobó que se trataba de una proteasa cisteínica y que su peso molecular, determinado en base a la concentración de grupos sulfhidrilo, era del orden de 20-23 kD (Cruz et al., 1974). Al igual que papaína, se trata de una proteína básica $(\mathrm{pI}=9,12)$ y su composición aminoacídica es similar a la de aquélla, aún cuando el número de cadenas laterales iónicas es mayor (Soriano et al., 1975). Su actividad es máxima a pH 8,5-9 frente a caseína y también manifiesta actividad esterolítica en un rango de pH 5-8 (Inei-Shizukawa et al., 1976).

\subsubsection{Proteasas de Euphorbiaceae}

Algunas Euphorbiaceae poseen látex con una actividad proteolítica que está en el mismo orden de magnitud que el de las encontradas en papaya e higo (Lennox \& Ellis, 1945; Jaffé, 1943), siendo interesante destacar que éstas no son proteasas cisteínicas.

Lynn \& Clevette-Radford (1988) realizaron un estudio comparativo sobre 17 proteasas aisladas y purificadas del látex de 8 especies de Euphorbiaceae. A partir de seis especies del género Euphorbia obtuvieron 13 proteasas: "euforbaína 1" (de E. lathyris), "euforbaína p" (de E. pulcherrima), "euforbaínas y 1-3" (de E. cyparissias), "euforbaínas t1-4" (a partir de E. tirucalli), "euforbaínas la 1-3" (de E. lactea) y "euforbaína Ic" (de $E$. lactea cristata). Las cuatro proteasas restantes provienen de otros dos géneros: "euforbaínas d $\mathrm{d}_{1-2}$ " (de Elaeophorbia drupifera) y "hevaína b" y "l" (de Hevea brasiliensis).

Todas las enzimas mencionadas fueron inhibidas por DFP o por PMSF, así como por reactivos específicos para histidina, demostrando la presencia de residuos de serina e histidina en el centro activo. Por otra parte, la actividad no fue afectada por EDTA ni por 
$O$-fenantrolina, lo que sugiere que no se trata de metaloproteinasas. Tampoco resultaron afectadas por mercaptoetanol ni por p-cloromercuribenzoato (un reactivo específico para grupos sulfhidrilo libres), con excepción de las euforbaínas $d_{1-2}$, que fueron parcialmente inhibidas por este último. Similarmente, el agregado de un reactivo carboxil-específico (diazo-DL-norleucina metiléster) no tuvo efecto sobre la actividad proteolítica, concluyéndose que se trata de proteasas serínicas, un grupo de proteasas con escasos representantes dentro de los vegetales.

Los pesos moleculares de estas proteasas varían entre 33 y $170 \mathrm{kD}$, pero en la mayoría es de 60-80 kD. Algunas de ellas presentan múltiples formas moleculares y todas son glicoproteínas, excepto la hevaína b. El análisis de la composición aminoacídica no muestra diferencias significativas entre ellas y los mapas peptídicos obtenidos como consecuencia de su acción sobre la cadena B de la insulina oxidada reveló que cada proteinasa posee una reactividad singular y que no muestran actividad exopeptidásica. Los valores de pl de la mayoría de estas enzimas se encuentran entre 5 y 7 , con valores extremos desde 4,0 hasta 9,1 . En casi todos los casos el pH óptimo se ubica en la zona neutra para los tres sustratos ensayados (azocaseína, azocolágeno y carbobenzoxi-glicina p-nitrofeniléster).

A partir del látex de tallos y raíces de Hura crepitans Jaffé (1943) obtuvo un precipitado acetónico al que denominó "huraína", con máxima actividad a pH 8 sobre gelatina y un pl estimado entre 4 y 5 , al que la presencia de cisteína, agua oxigenada 0 cianuro no modificaban su actividad proteolítica.

La actividad de la enzima resultó disminuida o anulada por inhibidores de tripsina de soja, poroto y Ascaris (Jaffé \& de Seild, 1960), no fue afectada por pcloromercuribenzoato pero sí inhibida por EDTA, activada por pequeñas dosis de $\mathrm{Fe}^{2+}$ (pero no $\mathrm{Fe}^{3+}$ ) e inhibida por $\mathrm{Zn}^{2+}$ (de Seild \& Gaede, 1961). Sin embargo, según los experimentos de Boller (1986) la proteasa del látex fresco es insensible al EDTA (10 a 50 $\mathrm{mM}$ ) y al $\mathrm{FeSO}_{4}(0,1$ a $10 \mathrm{mM})$, pero es completamente inhibida por PMSF ( 1 a $5 \mathrm{mM}$ ), por lo que huraína sería una típica proteasa serínica. 


\subsubsection{Proteasas de Moraceae}

Ficina, nombre dado a un conjunto de formas moleculares presentes en el látex de higos (Ficus spp.), es su representante casi excluyente. Su estudio fue promovido por el conocimiento previo de su empleo en medicina popular, debido al uso que hacían del látex algunos nativos de América Central y Sudamérica en el tratamiento de ciertas parasitosis intestinales (Caldwell \& Caldwell, 1929). Robbins (1930; Robbins y Lamson, 1934) estableció tempranamente la relación de causalidad entre el efecto antihelmíntico observado y la presencia de actividad proteolítica, especialmente notoria en el látex de Ficus carica y $F$. glabrata, las dos especies que desde entonces constituyen las principales fuentes de la proteasa.

Ficina es una proteasa sulfhidrilo-dependiente (Winnick et al., 1944; Cohen, 1958), con un único grupo -SH activo por molécula, aún cuando la misma contiene al menos otro grupo tiol y tres uniones disulfuro no esenciales para que se manifieste la actividad proteolítica (Liener, 1961; Englund et al., 1968; Malthouse \& Brocklehurst, 1976). La secuencia aminoacídica que corresponde a la vecindad del sitio activo que involucra al residuo de cisteína (Wong \& Liener, 1964; Husain \& Lowe, 1970a) refleja una notoria similitud con la de papaína (Light et al., 1964) y lo propio ocurre con el residuo histidina, que forma parte de una secuencia aminoacídica (Gleisner \& Liener, 1973) que es idéntica a la de papaína (Husain \& Lowe, 1970b) y casi igual a la de bromelina de tallo (Husain \& Lowe, 1968).

Como bromelina, ficina también es una glicoproteína (Friedenson \& Liener, 1974); la fracción polisacarídica está compuesta por glucosamina, manosa, galactosa, fucosa y xilosa en relación molar 5:2:1:1:1, respectivamente, cuya composición recuerda a la de bromelina de frutos, que carece de galactosa y posee menor contenido de glucosamina (Kito \& Murachi, 1969; Scocca \& Lee, 1969).

Williams et al. (1968) estudiaron 46 especies de Ficus, encontrando que sólo 13 de ellas poseían actividad proteolítica apreciable. El látex de $F$. stenocarpa resultó ser el de mayor actividad específica, seguido por los de $F$. carica y $F$. glabrata. Un estudio posterior (Kramer \& Whitaker, 1964) llevado a cabo sobre una de las variedades más promisorias, Ficus carica var. Kadota, permitió comprobar que todas las fracciones 
activas son muy básicas ( $\mathrm{pl}>9,6$ ) y que frente a caseína el $\mathrm{pH}$ de máxima actividad se sitúa en la zona neutra $(\mathrm{pH} 6,7-7,5)$.

Sgarbieri et al. (1964) ensayaron la actividad del látex de 16 variedades de Ficus carica por cromatografía de intercambio iónico, comprobando que de una a otra variedad se modifican tanto el número de fracciones activas (de 4 a 10) como la actividad. Por su parte Kramer \& Whitaker (1969a, 1969b) verificaron la existencia de variaciones estacionales en cuanto a la cantidad de proteína contenida en el látex y a la actividad específica del mismo, pero confirmaron que no existen diferencias en el número de formas moleculares que aparecen por cromatografía de intercambio y que la autolisis no es la causante del elevado número de fracciones activas.

Sugiura \& Sasaki (1974) estudiaron la composición de proteasas del látex de una variedad japonesa de higo (Ficus carica var. Horaishi), encontrando cuatro fracciones de similar composición (peso molecular 24 a 26 kD, pH óptimo 7-8, pI 8,3-10,2, semejante estabilidad a la temperatura y al $\mathrm{pH}$ ) y una fracción que contiene un $4,8 \%$ de carbohidratos, aunque en el resto de sus propiedades es similar a las demás.

A partir del látex de Ficus glabrata tratado con tetrationato de sodio (que impide una eventual autolisis de la enzima) Englund et al. (1968) obtienen cuatro fracciones activas, de las cuales sólo una de ellas resulta ser homogénea y cuya composición aminoacídica no difiere significativamente de los resultados previamente obtenidos por Marini-Bettolo et al. (1963) y por Metrione et al. (1967). El aminoácido N-terminal es leucina y el peso molecular es de $26 \mathrm{kD}$, cercano al consignado por otros autores (Bernhard y Gutfreund, 1956; Marini-Bettolo et al., 1963; Metrione et al., 1967). En cuanto a la especificidad de sustrato (cadena B de insulina oxidada), ficina exhibe una mayor afinidad hacia uniones peptídicas en las que el residuo más próximo al extremo $\mathrm{N}$ terminal es un aminoácido aromático.

Al estudiar la naturaleza de los principales componentes proteolíticos del látex de Ficus glabrata, Williams \& Whitaker (1969) comprueban que la composición aminoacídica de los mismos es esencialmente similar y que también lo son los mapas peptídicos que resultan luego de la hidrólisis tríptica, por lo que las diferencias cromatográficas observables podrían ser el resultado de una misma cadena polipeptídica plegada de distintas maneras (diferentes confórmeros) y en consecuencia con diferentes 
grupos expuestos en la superficie, o bien deberse a diferencias mínimas en la composición o en la secuencia aminoacídica. A similares conclusiones arriban Jones \& Glazer (1970) y Kortt et al. (1974a, 1974b).

Más recientemente Lynn y Clevette-Radford (1985) determinaron las propiedades de una proteasa presente en el "gomero" (Ficus elastica Roxb. et Homem, var. decora), a la que denominaron "Ficina E", que sorprendentemente no es una tiol-proteinasa, sino que pertenece al grupo de las proteinasas serínicas. La enzima tiene un peso molecular de 50 $\mathrm{kD}$, un pH óptimo de 6,0 y -a diferencia de los de ficina, bromelina y papaína- su pI es decididamente ácido $(3,7)$. El mapa peptídico obtenido al hacer actuar Ficina E sobre la cadena $\mathrm{B}$ de la insulina es totalmente diferente al que se obtiene con ficina y la composición aminoacídica de esta nueva proteasa es también muy distinta a la de aquélla.

En especies pertenecientes a otros géneros de Moraceae los estudios realizados son muy básicos: en Brosimum alicastrum, Broussonetia papyrifera y Morus nigra Robbins \& Lamson (1934) simplemente mencionan que detectaron actividad proteolítica sobre gelatina, en tanto que Tauber (1949) extrajo una proteasa no sulfhidrílica del látex de Maclura pomifera, con máxima actividad sobre gelatina a pH 6,45.

\subsection{Principales aplicaciones de las proteasas}

\subsubsection{Tiernización de carnes}

Como la mayoría de los productos naturales, las enzimas proteolíticas han sido utilizadas empíricamente durante mucho tiempo, especialmente en materia de alimentación y salud. Un buen ejemplo lo constituye el empleo del jugo de mamón (Carica papaya L.), con el que los habitantes de muchas regiones de Centro y Sudamérica hacen más tiernas las carnes que consumen. Las proteasas contenidas en dicho jugo provocan la tiernización por hidrólisis parcial de las proteínas del tejido conectivo (colágeno y elastina) y en menor grado las de las mismas fibras musculares. Si bien las proteasas pueden aplicarse de muy diversas maneras, actualmente en la industria de la carne se logra un excelente tiernizado inyectando por vía endovenosa al animal antes de ser faenado una solución de enzima 
reversiblemente inactivada. La proteasa es reactivada por el poder reductor que adquiere el músculo luego de la muerte (Kang, 1978) y manifiesta su máxima actividad con el incremento de la temperatura durante el proceso de cocción (Bernholdt, 1982). Con este tratamiento también se mejora la digestibilidad del producto.

\subsubsection{Elaboración de cerveza}

Otra aplicación importante de las proteasas es el uso que se hace de ellas en la industria de la cerveza, con el objeto de proporcionar a la misma una buena estabilidad coloidal a bajas temperaturas, es decir impedir que como consecuencia del enfriamiento se manifieste turbiedad o que sedimenten componentes que se mantenían solubles a temperatura ambiente. El fenómeno anterior es debido a la presencia de un complejo tanoproteico (tanino-proteína) que resulta soluble en caliente o a temperatura ambiente, pero que tiene tendencia a precipitar en frío. Tanto las proteínas como los compuestos polifenólicos provienen de las materias primas usadas en la preparación de la cerveza (cebada y lúpulo). Un modo de resolver el problema es impedir la formación del complejo o digerirlo parcialmente luego de formado; en este último caso se usan enzimas proteolíticas, en especial papaína, aunque también se han ensayado ficina, bromelina y pepsina. Debe tenerse en cuenta que la hidrólisis requiere ser controlada, ya que la cerveza debe mantener una adecuada proporción de proteína coloidal, necesaria para que la misma tenga "cuerpo" y produzca espuma abundante y duradera (Sicard, 1982).

\subsubsection{Elaboración de quesos}

Las proteasas se utilizan en la industria láctea, en especial en la fabricación de quesos. La quimosina, una endopeptidasa que integra los fermentos gástricos de los rumiantes, ha sido tradicionalmente usada para producir la coagulación de la leche. Este proceso ocurre en dos etapas, la primera de las cuales es de naturaleza enzimática y 
consiste fundamentalmente en la hidrólisis de una unión peptídica específica de la kappacaseína (Fox, 1982), haciéndola susceptible a coagular englobando lípidos y proteínas, en presencia de $\mathrm{Ca}^{2+}$ y calor (lo que constituye la segunda etapa). Como sustituyentes de la renina se han ensayado otras enzimas: pepsina bovina y porcina, ficina y proteasas fúngicas de Mucor miehei, M.pusillus y Endothia parasitica, aunque su uso no se ha generalizado.

\subsubsection{Panificación}

Durante la panificación se adicionan proteasas fúngicas (Aspergillus oryzae), papaína o bromelina para mejorar la manipulación de la masa, así como su elasticidad y la textura del gluten, lo que finalmente provoca un incremento sustancial del volumen de aquélla, con la consiguiente reducción del tiempo de amasado (Sicard, 1982).

\subsubsection{Obtención de proteínas modificadas para la industria alimentaria}

En los párrafos anteriores se han analizado los principales procesos de elaboración de alimentos en los que intervienen enzimas proteolíticas. Otro importante uso de estas enzimas es la obtención de proteínas parcialmente hidrolizadas o de hidrolizados proteicos para ser luego empleados en la producción de otros alimentos.

Un ejemplo interesante es la producción de quesos modificados por enzimas (Enzyme Modified Cheeses, EMC), los que tienen un sabor 5 a 15 veces más intenso que los quesos no modificados. Estos EMC se utilizan como agentes saborizantes reemplazando total o parcialmente el ingrediente original en la fabricación de productos que normalmente contienen quesos (Kilara, 1985).

Por otra parte, la hidrólisis parcial de las proteínas permite modificar ciertas propiedades físicoquímicas de las mismas; así es como se ha logrado incrementar la solubilidad de las proteínas de semillas de soja (Puski, 1975), de algodón (Jost \& Monti, 1977) y de maní, caso en el que han resultado adecuadas papaína, bromelina y ficina 
(Arzu et al., 1972). Los productos obtenidos pueden emplearse en la elaboración de bebidas, sopas y salsas. En cuanto al incremento de la capacidad emulgente, se obtuvieron buenos resultados con proteínas de soja y de trigo para su uso en mayonesas. salsas y aderezos (Sekul \& Ory, 1977).

Es de particular importancia el incremento del poder espumígeno de las proteínas para ser utilizadas en la fabricación de "souffles", "mousses", merengues, helados y cremas. En tal sentido se han obtenido proteínas modificadas que producen espumas abundantes y estables a partir de semillas de soja y trigo.

También se obtienen por degradación enzimática hidrolizados proteicos, los que han encontrado creciente aplicación como aditivos alimentarios, ya que proveen aminoácidos libres y péptidos de bajo peso molecular (Kilara, 1985).

\subsubsection{Aditivos en polvos detergentes}

Una aplicación de las proteasas que ha adquirido gran importancia en los últimos tiempos es su incorporación a polvos detergentes (Whitaker, 1982), en los que están habitualmente asociadas a lipasas y amilasas, siendo las de origen microbiano las más utilizadas.

\subsubsection{Manufactura de cueros}

Otro importante proceso industrial en el que se emplean enzimas proteolíticas es la manufactura de cueros, ya sea en la etapa previa de la depilación de la piel como en la posterior del "batido", cuyo objetivo es preparar el cuero para el teñido y que consiste en la remoción de restos de pelos, glándulas, células epiteliales y tejidos superficiales no separados por los tratamientos previos. En este caso se utiliza principalmente pancreatina, pero también se han ensayado con buenos resultados papaína, bromelina y proteasas bacterianas (en especial la obtenida de Bacillus subtilis) y fúngicas de variado origen (Sicard, 1982). 


\subsubsection{Industria textil}

A los efectos de aumentar la resistencia a la tracción y a la abrasión, las fibras textiles son "encoladas" con una preparación de polímeros ("colas"). Con posterioridad al hilado se debe proceder a "desencolar" los hilos para restituir las propiedades de los mismos. Las fibras artificiales son habitualmente impregnadas con gelatina y para su desencolado se usa la proteasa neutra de Bacillus subtilis o la proteasa alcalina de $B$. licheniformis (Sicard, 1982).

\subsubsection{Acción farmacológica}

Las enzimas proteolíticas han sido utilizadas en tratamientos post-quirúrgicos para el desbridamiento de heridas y en clínica médica gastroenterológica como coadyuvantes en el tratamiento de trastornos digestivos, en este último caso asociadas a otras enzimas hidrolíticas (Mantell et al., 1985). Pero la aplicación más trascendente de las mismas obedece a sus probadas propiedades antiinflamatorias (Netti et al., 1972), siendo papaína, bromelina y ficina las proteasas más ampliamente utilizadas en tal sentido.

Informaciones relativamente recientes han dado cuenta de una presunta actividad citostática de la bromelina (Batkin, et al., 1988a, 1988b; Maurer et al., 1988), pero el anuncio no ha sido confirmado por posteriores investigaciones. Mucho más recientemente se ha ensayado en el tratamiento de hernias de discos intervertebrales la aplicación local de quimopapaína inyectable, que actuaría hidrolizando los proteoglicanos presentes en los núcleos pulposos ("quimionucleolisis") responsables de la afección (Walreavens et al., 1993). 


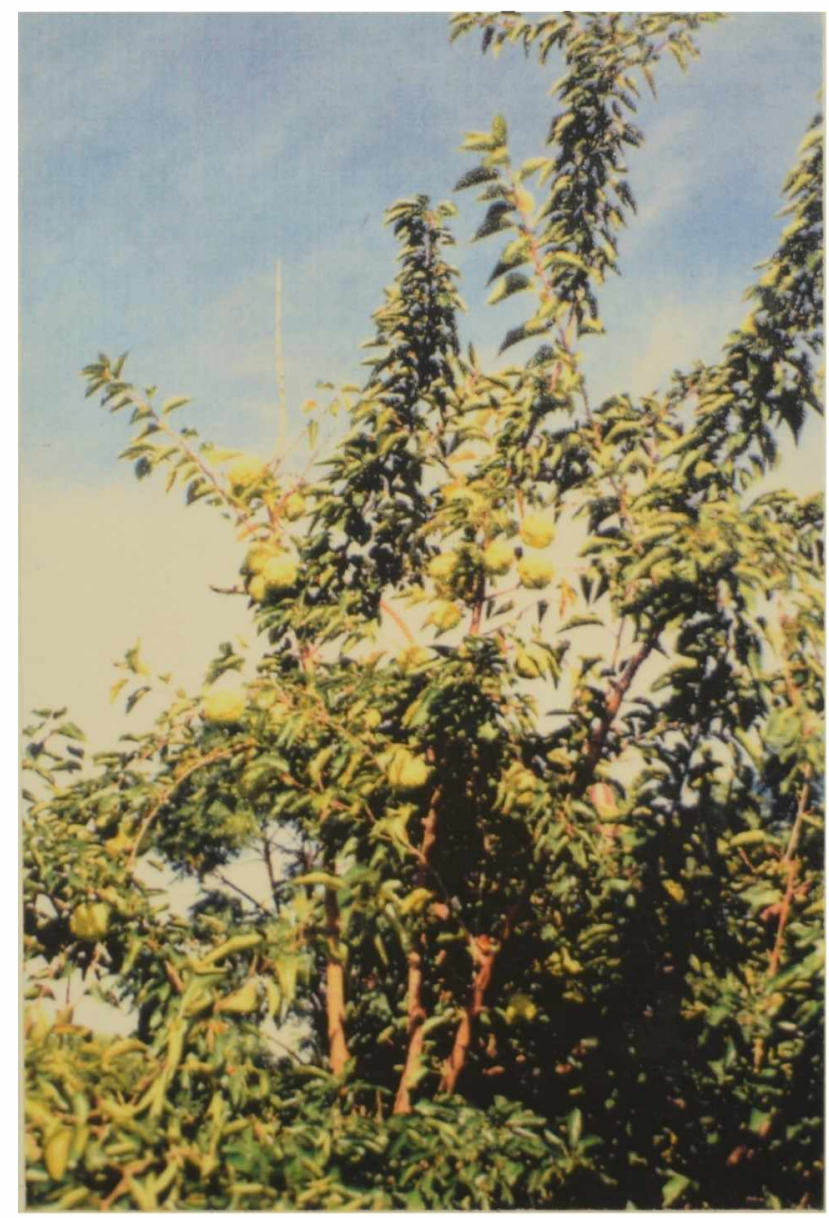

2. Objetivos 


\subsection{Motivos de la elección del tema}

En términos económicos, las enzimas proteolíticas representan casi las dos terceras partes de las enzimas que se comercializan en el mercado mundial, a pesar de que el número de proteasas de aplicación industrial no supera la docena, incluidas tanto las de origen vegetal (papaína, ficina, bromelina) como las de origen animal (pancreatina, pepsina, quimosina) o microbiano (alcalasa, neutrasa, proteasas fúngicas).

En principio, toda proteasa está capacitada para degradar cualquier sustrato proteico, aunque el grado de hidrólisis alcanzado y el tipo de productos obtenidos no sean los mismos prácticamente en ningún caso. La elección de una u otra clase de proteasa dependerá entonces de su modo de acción y de la posibilidad de que el mismo se adapte a las condiciones particulares del proceso en el que se intente aplicarla $(\mathrm{pH}$, temperatura, fuerza iónica, presencia de otras sustancias, características del medio).

En virtud de lo expuesto, resulta sorprendente el reducido número de proteasas que han sido aisladas, purificadas y caracterizadas. En el caso de las plantas superiores, el número de especies investigadas en tal sentido está muy lejos de representar siquiera el uno por mil de las especies existentes.

En lo que se refiere a la Argentina, la variedad de zonas fitogeográficas existentes ha generado una importante flora autóctona, a la que debe sumarse un buen número de especies introducidas por cultivo. Sin embargo no existen antecedentes sobre el aislamiento de fitoproteasas provenientes de plantas que crecen en el país, a excepción de los estudios realizados en nuestro laboratorio sobre algunas especies de Bromeliaceae.

\subsection{Finalidades específicas}

En la búsqueda de una especie vegetal que resultara buena productora de proteasas, utilizando como criterios selectivos la biomasa disponible, la accesibilidad de su obtención y la posibilidad de su aprovechamiento industrial, se realizaron ensayos preliminares en especies pertenecientes a taxones promisorios en este sentido. Finalmente se seleccionaron 
los frutos de Maclura pomifera (Raf.) Schneid. (Moraceae) para estudiar las proteasas presentes en el látex que contienen los mismos.

Una vez elegido el material vegetal, se elaboró la estrategia experimental que permitiera conseguir los siguientes objetivos:

a) Establecer la relación entre el grado de madurez de los frutos, la producción de látex y el contenido de proteasas de los mismos.

b) Obtener preparaciones enzimáticas crudas y determinar las condiciones óptimas para su conservación.

c) Caracterizar las preparaciones crudas en cuanto al efecto del pH. la temperatura. la fuerza iónica y el agregado de activadores e inhibidores. así como conocer su estabilidad durante lapsos variables en diferentes condiciones de pH y temperatura y ensayar la actividad proteulitica frente a diferentes sustratos naturales y sintéticos.

d) Someter las preparaciones a un proceso de purificación que permita obtener una o más fracciones de elevada actividad especifica con alto grado de rendimiento.

e) Caracterizar las fracciones asi purificadas. 


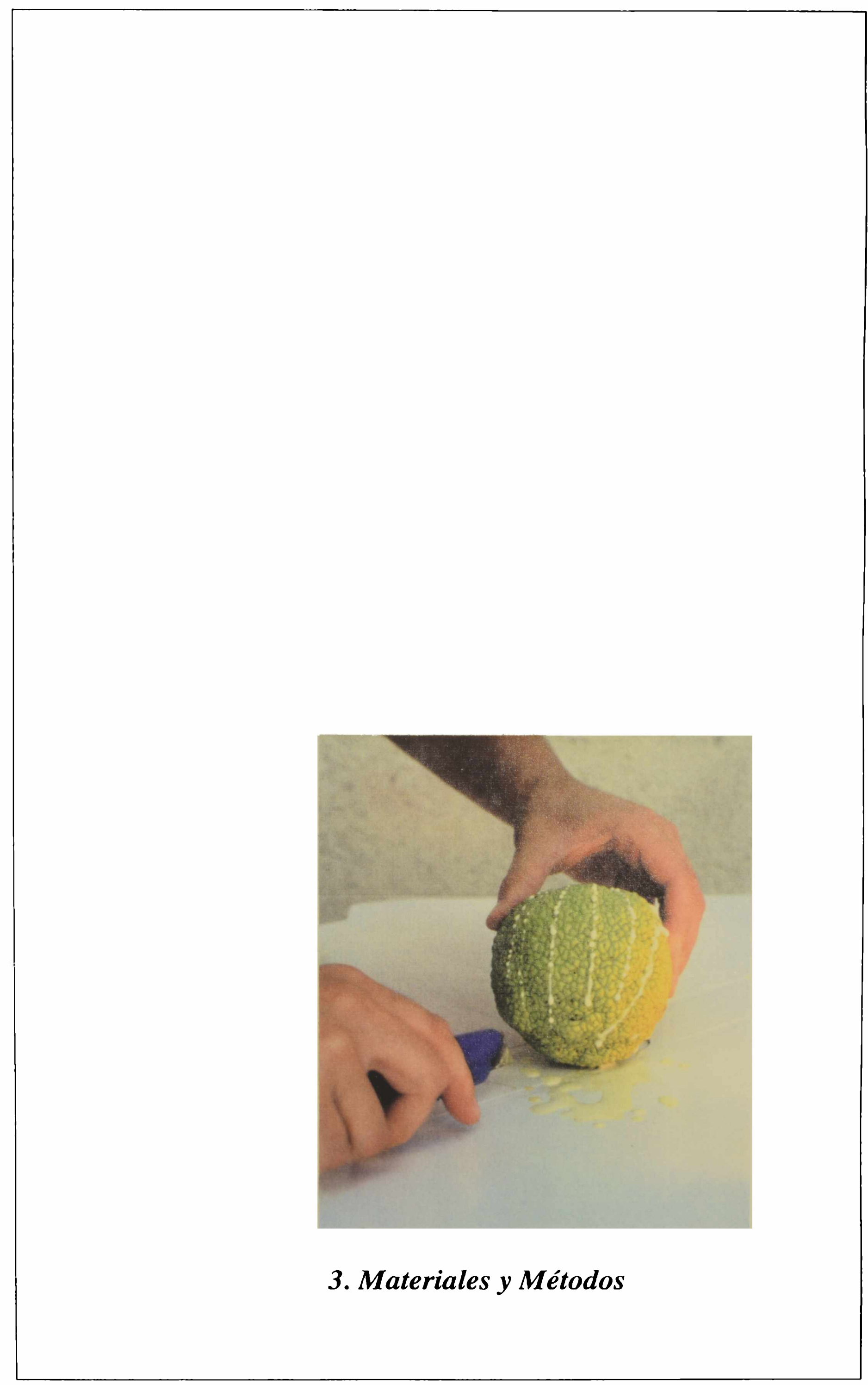




\subsection{Material vegetal}

Las proteasas cuyo estudio constituye el objeto del presente trabajo forman parte del látex proveniente de frutos maduros de Maclura pomifera (Raf.) Schneid. (Moraceae). El material fue recogido en Villa Elisa (Provincia de Buenos Aires) en enero, febrero, marzo y abril de 1989, marzo y abril de 1990, abril de 1991, abril de 1992, abril de 1993 y abril de 1994.

La especie es ampliamente cultivada en toda la región templado-cálida de nuestro país para formar cercos vivos y rompevientos y también con fines ornamentales, por su agradable follaje abierto de color verde brillante y sus grandes frutos con aspecto de naranjas rugosas (de allí la denominación "osage orange" que se da a la especie en EE.UU.). Se trata de un árbol dioico, de mediano tamaño, originario de América boreal. El nombre le fue impuesto al género en honor del geólogo norteamericano W. Maclure (Bailey, 1953).

Las ramitas son de color verde claro, glabras al principio, luego con espinas de hasta $6 \mathrm{~cm}$ de largo. Posee hojas caedizas, cortamente pecioladas, aovadas a oblongo-lanceoladas, acuminadas, pubescentes en la foliación, llegando a ser prontamente glabras, lustrosas en la cara superior, de 5 a $15 \mathrm{~cm}$ de largo.

Las flores son unisexuales, pequeñas, apétalas y con cáliz tetralobado. Las flores masculinas, de 2 a $4 \mathrm{~cm}$ de largo, presentan cuatro estambres opositipétalos y anteras bitecas de dehiscencia longitudinal, son pediceladas y están dispuestas en racimos péndulos sobre ramas del año anterior. Las flores femeninas son sésiles, agrupadas en compactos capítulos esféricos de $2 \mathrm{~cm}$ de ancho, insertas sobre cortos pedúnculos. El ovario es unilocular con estigma piriforme, largo y plumoso. El fruto es un sincarpio esférico, rugoso, verdeamarillento, de 10 a $15 \mathrm{~cm}$ de diámetro, formado por la concrescencia de pequeñas drupas oblongas. Florece en primavera y sus frutos maduran entre el verano y el otoño. La propagación se produce usualmente por semillas, aunque también pueden obtenerse nuevas plantas a partir de gajos o estacas de tallos o raíces.

La corteza de la raíz es utilizada como colorante amarillo y la del tronco, de color naranja oscuro, es empleada a veces para curtir cueros (Dimitri, 1978). 


\subsection{Relación entre el grado de madurez de los frutos, la producción de látex y el contenido en proteasas de los mismos.}

Con el objeto de determinar en qué medida el grado de desarrollo del fruto está relacionado con la producción de látex y de proteasas y para establecer el período óptimo de recolección de los mismos, se obtuvieron frutos en distintos estadios de maduración provenientes de un único ejemplar de Maclura pomifera, durante el período enero-abril de 1989; el grado de maduración fue expresado en semanas a partir del inicio de la floración.

En cada oportunidad se recolectaron 5 frutos, que fueron pesados, medidos y lavados; una vez secos se les extrajo el látex siguiendo el procedimiento descripto más adelante.

A las suspensiones así obtenidas se les determinó la actividad caseinolítica como se indica en 3.4.1. y el contenido en proteínas de acuerdo a lo especificado en 3.6., a efectos de expresar los resultados como actividad específica de cada muestra.

\subsection{Obtención de las preparaciones crudas}

Previamente a la obtención del látex los frutos fueron escrupulosamente lavados bajo un chorro de agua corriente con la ayuda de un cepillo suave, enjuagados dos veces con agua destilada y pesados una vez secos.

El látex fue obtenido practicando incisiones superficiales de una profundidad no mayor a los $2 \mathrm{~mm}$ (efectuando incisiones más profundas o cortando los frutos no se obtuvo un mayor rendimiento en látex). De esta manera se provocó la exudación de un látex semifluido, de color blanquecino, que fue recibido sobre un pequeño volumen de una solución de buffer fosfatos $0,1 \mathrm{M}$ de $\mathrm{pH}$ 6,0 conteniendo EDTA $5 \mathrm{mM}$ sumergida en un baño de hielo-agua para prevenir la proteólisis. El agregado de EDTA obedece a la necesidad de evitar la acción de las fenoloxidasas, que poseen $\mathrm{Cu}^{2+}$ en su centro activo (Anderson, 1968), en tanto que el valor de $\mathrm{pH}$ elegido es lo suficientemente alejado del pH óptimo como para minimizar la autodigestión durante el proceso.

Las preparaciones crudas se obtuvieron diluyendo y centrifugando la suspensión anterior a $4^{\circ} \mathrm{C}$ y $16.000 \mathrm{~g}$ durante 20 minutos. Luego de eliminar una película blanquecina 
que flota en la superficie y un pellet amarillo verdoso (lo que permitió la remoción de gomas y otros materiales insolubles), la solución $(25 \mathrm{ml}$ corresponden a $1 \mathrm{ml}$ de látex) se filtró a través de papel y se congeló o liofilizó.

\subsection{Ensayo de la actividad proteolítica}

Si bien el sustrato proteolítico empleado en la mayoría de los casos fue caseína, en algunas experiencias se utilizaron azocaseína, azocoll, hemoglobina y proteínas de soja.

\subsubsection{Caseína}

Se preparó suspendiendo $1 \mathrm{~g}$ de caseína tipo Hammarsten (Research Organics) en 100 $\mathrm{ml}$ de solución buffer; la suspensión se colocó en un baño de agua que se llevó a ebullición y se mantuvo durante 20 minutos en esas condiciones. La solución resultante se filtró por papel en caliente y se utilizó el mismo día en que fue preparada.

La mezcla de reacción contiene $1,1 \mathrm{ml}$ de solución de caseína al $1 \%$ y $0,1 \mathrm{ml}$ de solución de la enzima, disueltas en buffer Tris-ClH $0,1 \mathrm{M}$ de $\mathrm{pH} 8,5$. La reacción fue llevada a cabo a $37^{\circ} \mathrm{C}$ y detenida por la adición de $1,8 \mathrm{ml}$ de ácido tricloroacético al $5 \%$, luego de lo cual los tubos fueron centrifugados a $4.000 \mathrm{~g}$ durante 20 minutos, determinándose la absorbancia de los sobrenadantes a $280 \mathrm{~nm}$, medida a través de una celda de $1 \mathrm{~cm}$ de paso. En todos los casos fueron realizados ensayos en blanco agregando en primer término el ácido tricloroacético.

Siguiendo el criterio de Sarath et al. (1989) para expresar la actividad enzimática cuando se utilizan sustratos proteicos, se definió para este caso una unidad arbitraria (Unidad caseinolítica, $U_{\text {cas }}$ ), que corresponde a la cantidad de enzima requerida para producir un incremento de una unidad de absorbancia a $280 \mathrm{~nm}$ al cabo de un minuto, en las condiciones de ensayo. 


\subsubsection{Azocaseína}

Esta técnica presenta la ventaja de su mayor sensibilidad y la posibilidad de efectuar las mediciones en el espectro visible, aunque su ejecución es algo más compleja que la anteriormente descripta.

Para la preparación de la azocaseína se utilizó la técnica de Charney \& Tomarelli (1947) ligeramente modificada, que requiere la preparación previa de una solución 0,01 M de ácido sulfanílico diazotado y de una solución de caseína al 7,5\%.

La solución de ácido sulfanílico diazotado se preparó disolviendo 10 milimoles de nitrito de sodio y 10 milimoles de ácido sulfanílico en $300 \mathrm{ml}$ de agua destilada, que se virtieron sobre 25 milimoles de ácido clorhídrico concentrado y 2 milimoles de bromuro de sodio, agitando durante 1 hora a $20^{\circ} \mathrm{C}$. La solución se llevó a un litro con agua destilada y se conservó en heladera.

La solución de caseína se preparó agregando $15 \mathrm{~g}$ de caseína tipo Hammarsten lentamente y con agitación suave sobre $200 \mathrm{ml}$ de una solución de carbonato de sodio al $5 \%$ $(\mathrm{p} / \mathrm{v})$ a temperatura inferior a $60^{\circ} \mathrm{C}$.

La solución de ácido sulfanílico diazotado fue vertida lentamente sobre la de caseína, manteniendo la temperatura por debajo de $5^{\circ} \mathrm{C}$ y asegurándose que el $\mathrm{pH}$ fuera inferior a 9 mediante el agregado de ácido clorhídrico $1 \mathrm{M}$. El conjunto se transfirió a la heladera con agitación constante durante 5 o más horas. Al cabo de ese tiempo se agregó ácido clorhídrico $0,2 \mathrm{M}$ hasta $\mathrm{pH} 6,5$ y se dializó a igual temperatura contra cloruro de sodio $0,1 \mathrm{M}$ (15 volúmenes) durante 12 horas y luego contra agua destilada (15 volúmenes) otras 12 horas. La solución dializada fue fraccionada y liofilizada.

La mezcla de reacción conteniendo $250 \mu \mathrm{l}$ de azocaseína al $2 \%$ en Tris- $\mathrm{HCl} 0,1 \mathrm{M}$ de $\mathrm{pH} 8,0$ y $150 \mu \mathrm{l}$ del extracto enzimático se incubó a $37^{\circ} \mathrm{C}$. La reacción se detuvo agregando $1,2 \mathrm{ml}$ de ácido tricloroacético al $10 \%$; la mezcla se mantuvo en reposo durante 15 minutos y luego se centrifugó durante 3 minutos a $8.000 \mathrm{~g}$. Se virtieron $1,2 \mathrm{ml}$ del sobrenadante en un tubo de ensayo conteniendo $1,4 \mathrm{ml}$ de $\mathrm{NaOH} 1 \mathrm{M}$ y se midió la absorbancia a $440 \mathrm{~nm}$ a través de una celda de $1 \mathrm{~cm}$ de paso. En todos los casos fueron realizados ensayos en blanco agregando en primer término el ácido tricloroacético. 
La unidad de actividad enzimática ( $U_{\text {azocas }}$ ) fue definida como la cantidad de enzima necesaria para producir un incremento de una unidad de absorbancia a $440 \mathrm{~nm}$ por minuto en las condiciones de ensayo.

\subsubsection{Azocolágeno}

La mezcla de reacción contiene $10 \mathrm{mg}$ de azocoll (Sigma), $200 \mu \mathrm{l}$ de solución de enzima y $300 \mu \mathrm{l}$ de buffer Tris-ClH $0,1 \mathrm{M}$ de pH 8,5. La reacción se llevó a cabo a $37^{\circ} \mathrm{C}$ y fue detenida por el agregado de $3 \mathrm{ml}$ de agua fría $\left(4^{\circ} \mathrm{C}\right)$, luego de lo cual los tubos fueron mezclados vigorosamente, el contenido removido por filtración a través de papel de filtro Whatman $\mathrm{N}^{0} 1$ y la absorbancia de la solución medida a $520 \mathrm{~nm}$ a través de una celda de 1 $\mathrm{cm}$ de paso. En todos los casos fueron realizados ensayos en blanco reemplazando la solución de enzima por una cantidad equivalente de buffer.

En este caso la unidad de actividad enzimática ( $U_{\text {azocoll }}$ ) fue definida como la cantidad de enzima necesaria para producir un incremento de una unidad de absorbancia por minuto en las condiciones de ensayo (O'Reilly et al., 1981).

\subsubsection{Hemoglobina}

Se utilizó la técnica de Anson (1938) ligeramente modificada. Para obtener el sustrato (hemoglobina desnaturalizada por acción de urea), una solución conteniendo $8 \mathrm{ml}$ de $\mathrm{NaOH}$ $1 \mathrm{~N}, 72 \mathrm{ml}$ de agua destilada, $36 \mathrm{~g}$ de urea y $10 \mathrm{ml}$ de hemoglobina (Sigma) al 22\% (p/v) fue mantenida a $25^{\circ} \mathrm{C}$ durante 60 minutos, luego de lo cual se le adicionaron $4 \mathrm{~g}$ de urea disueltos en $10 \mathrm{ml}$ de $\mathrm{KH}_{2}\left(\mathrm{PO}_{4}\right)$. Esta solución de hemoglobina desnaturalizada fue almacenada a $4^{\circ} \mathrm{C}$, estabilizada por el agregado de merthiolate al $2 \%(\mathrm{p} / \mathrm{v})$.

La mezcla de reacción conteniendo $0,5 \mathrm{ml}$ de la solución de hemoglobina desnaturalizada y $0,1 \mathrm{ml}$ de la preparación enzimática fue incubada durante 10 minutos a $37^{\circ} \mathrm{C}$; la reacción se detuvo por el agregado de $1 \mathrm{ml}$ de ácido tricloroacético $0,3 \mathrm{~N}$, la mezcla se mantuvo en reposo durante 30 minutos y se centrifugó durante 20 minutos a 5.000 g. Sobre $100 \mu \mathrm{l}$ de sobrenadante se practicó la reacción de Folin \& Ciocalteau (1927), 
midiendo la absorbancia de los productos obtenidos a $750 \mathrm{~nm}$ a través de una celda de $1 \mathrm{~cm}$ de paso. A los efectos de poder expresar los resultados en miliequivalentes de tirosina se practicó la misma reacción sobre una solución patrón de tirosina 0,16 N. En todos los casos fueron realizados ensayos en blanco agregando en primer término el ácido tricloroacético.

La unidad de actividad enzimática (Unidades Anson) fue definida como la cantidad de enzima que digiere a la hemoglobina desnaturalizada en las condiciones de ensayo, liberando por minuto una cantidad de productos no precipitables con ácido tricloroacético que en presencia del Reactivo de Folin \& Ciocalteau producen una absorbancia a $750 \mathrm{~nm}$ equivalente a la generada por un miliequivalente de tirosina.

\subsubsection{Proteínas de soja}

El objetivo de este experimento fue determinar el grado de hidrólisis de las proteínas presentes en concentrados de soja por acción de una cantidad definida de la enzima estudiada y analizar los productos generados a lo largo del tiempo, en comparación con la proteólisis producida por alcalasa (preparación comercial obtenida de Bacillus licheniformis, Novo Industri A/S, Denmark) en la misma relación enzima/sustrato.

El concentrado de soja fue preparado agitando $100 \mathrm{~g}$ de harina de soja desgrasada (origen Brasil) durante 12 horas a $4^{\circ} \mathrm{C}$ con $1000 \mathrm{ml}$ de etanol de $70^{\circ}$; la dispersión se centrifugó, el sedimento se trató del mismo modo durante 1 hora y se secó en estufa a $50^{\circ} \mathrm{C}$ durante 24 horas.

El seguimiento de la hidrólisis se realizó con un "pH-stat" manual empleando una microbureta tipo Bahn, un $\mathrm{pH}$-metro, un vaso de doble camisa para termostatizar la mezcla de hidrólisis y un baño de temperatura graduable. El pH se mantuvo constante por adición de $\mathrm{NaOH} 2 \mathrm{~N}$ cada vez que el mismo descendió 0,1 unidad. La reacción se detuvo por disminución del pH a 4,2 mediante el agregado de ácido $\mathrm{HCl} \perp \mathrm{N}$ y la inactivación de la enzima se obtuvo por calentamiento a $75^{\circ} \mathrm{C}$ durante 10 minutos. En todos los experimentos la temperatura fue fijada en $45^{\circ} \mathrm{C}$ y se utilizaron $100 \mathrm{ml}$ de una dispersión de concentrado de soja al $8 \%$ en agua (5,6\% en proteínas) que fue llevada con $\mathrm{NaOH}$ al valor de $\mathrm{pH}$ elegido $(8,0,9,0$ ó 10,0). En todos los casos fueron realizados ensayos en blanco reemplazando la solución de enzima por una cantidad equivalente de agua destilada. 
El grado de hidrólisis (DH) se calculó de acuerdo a la siguiente fórmula (AdlerNissen, 1986):

$$
\mathrm{DH}=\mathrm{V}_{\mathrm{NaOH}} \times \mathrm{N}_{\mathrm{NaOH}} \times 1 / \alpha \times 1 / \mathrm{MP} \times 1 / h_{\text {tot }} \times 100 \%
$$

donde $\alpha$ es el grado de disociación promedio de los grupos $\alpha-\mathrm{NH}-$, MP es la masa de proteína en gramos (Kjeldahl) y $h_{\text {tot }}$ el número total de uniones peptídicas en el sustrato proteico $(\mathrm{meq} / \mathrm{g})$.

\subsection{Ensayo de la actividad esterolítica con sustratos sintéticos}

La utilización de sustratos sintéticos del tipo $N$-carbobenzoxi-p-nitrofenilésteres de Laminoácidos, en los cuales están bloqueados tanto el grupo $\alpha-\mathrm{NH}_{2}$ como el $\alpha$-COOH del resto aminoacídico (en el último caso con un grupo cromóforo), permite la determinación de la actividad endoesterásica relativa respecto al aminoácido que aporta el grupo carboxilo.

La mezcla de reacción contiene $1,9 \mathrm{ml}$ de buffer Tris- $\mathrm{HCl} 0,1 \mathrm{M}$ de $\mathrm{pH} 8,0,1 \mathrm{ml}$ de solución de sustrato ( $1 \mathrm{mM}$ en dioxano) y $0,1 \mathrm{ml}$ de solución de enzima. La reacción fue llevada a cabo a $30^{\circ} \mathrm{C}$ y se midieron durante 3 minutos los cambios en la absorbancia a 405 nm, máximo del espectro de absorción del 4-nitrofenolato liberado por la enzima. La hidrólisis no enzimática correspondiente a cada uno de los sustratos se determinó reemplazando la solución de enzima por $0,1 \mathrm{ml}$ de buffer. Los ensayos fueron realizados por triplicado.

La unidad enzimática $\left(\mathrm{U}_{\mathrm{cbz}}\right)$ fue definida como la cantidad de enzima que libera un micromol de p-nitrofenolato por minuto a $30^{\circ} \mathrm{C}$ y $\mathrm{pH} 8,0$. A los efectos de calcular los micromoles de 4-nitrofenolato producidos en la reacción se confeccionó una curva patrón utilizando este reactivo en el rango de 15 a $70 \mu \mathrm{M}$.

Se utilizaron los $N$-carbobenzoxi-p-nitrofenilésteres de los siguientes aminoácidos: Lalanina, L-asparagina, L-fenilalanina, glicina, L-leucina, L-lisina, L-tirosina, L-triptofano y L-valina, así como el $N$-carbobenzoxi- $\beta$-bencil-L-ácido aspártico-p-nitrofeniléster y el $N$ carbobenzoxi-S-bencil-L-cisteína-p-nitrofeniléster. Cabe destacar que sólo se ensayaron los derivados de los aminoácidos que pueden obtenerse comercialmente. 


\subsection{Determinación del contenido de proteínas}

Se utilizó el método de Bradford (1976), basado en que la unión del Coomassie Blue G-250 a la proteína produce un corrimiento del máximo de absorbancia de $465 \mathrm{~nm}$ (forma roja del colorante libre) a $595 \mathrm{~nm}$ (forma azul del complejo colorante-proteína). El método resulta especialmente apto para la valoración de proteínas en extractos vegetales, que frecuentemente contienen sustancias de naturaleza fenólica que interfieren con el clásico método de Lowry (Peterson, 1979).

Las curvas de calibración se confeccionaron utilizando seroalbúmina bovina (Sigma) en el rango de 0,2-1,4 $\mathrm{mg} / \mathrm{ml}$ para el ensayo estándar y en el de $5-100 \mu \mathrm{g} / \mathrm{ml}$ para el microensayo.

En las experiencias cromatográficas el perfil de proteínas se estimó por medida de la absorbancia directa a $280 \mathrm{~nm}$.

\subsection{Determinación del contenido de hidratos de carbono}

El contenido de hidratos de carbono se determinó por el método de Dubois et al. (1957), basado en la formación de un compuesto coloreado con máximo de absorbancia a $490 \mathrm{~nm}$ por reacción del fenol con los glúcidos (azúcares y sus metil derivados, oligosacáridos y polisacáridos solubles), en presencia de ácido sulfúrico concentrado. La curva de calibración se confeccionó utilizando glucosa (Mallinckrodt) en el rango de 10-100 $\mu \mathrm{g} / \mathrm{ml}$.

\subsection{Conservación de las preparaciones crudas}

Dado lo reducido del período en el que los frutos alcanzan el grado de madurez óptimo para la producción de proteasas, el almacenamiento del material en estudio es un aspecto crítico. La conservación de los frutos a temperaturas inferiores a $0^{\circ} \mathrm{C}$ fue descartada porque el proceso de congelamiento y descongelamiento provoca la desorganización de las estructuras secretoras, con la consiguiente disminución de actividad proteolítica del material 
por dilución y/o inactivación de las proteasas. En consecuencia se almacenaron preparaciones crudas a $-20^{\circ} \mathrm{C}$ y se ensayó el efecto del tiempo de almacenamiento sobre la actividad caseinolítica de las mismas, para lo cual se conservaron congeladas a $-20^{\circ} \mathrm{C}$ alícuotas de 5 $\mathrm{ml}$. Luego de $5,10,20,30,60,120$ y 180 días fueron descongeladas dos muestras correspondientes a cada tiempo de conservación, determinándose la actividad residual

Por otro lado se ensayó el efecto de la liofilización sobre la actividad caseinolítica de las preparaciones crudas. En este caso 10 alícuotas de $2 \mathrm{ml}$ de dichas preparaciones fueron congeladas en frascos-ampolla por rotación dentro de un recipiente conteniendo aire líquido. De esta manera se obtiene una película delgada, con lo que se reduce el tiempo de congelamiento y se facilita la liofilización. Cinco muestras fueron liofilizadas en un liofilizador FIC, modelo L2 y las restantes se almacenaron congeladas para ser empleadas como referencia. Se determinó la actividad caseinolítica residual tanto en los liofilizados como en las referencias.

\subsection{Efecto de pH sobre la actividad proteolítica}

El perfil de $\mathrm{pH}$ característico de las preparaciones enzimáticas se determinó utilizando alternativamente caseína o azocoll como sustratos.

Cuando la actividad proteolítica se midió sobre caseína, según la técnica descripta en 3.4.1., el rango de pH ensayado fue desde 6,0 (debido a la escasa solubilidad de la caseína a valores menores) hasta 11,0, con intervalos de 0,5 unidad de $\mathrm{pH}$. En las determinaciones se emplearon soluciones 0,01 M de los siguientes buffers: Mes, Mops, Taps, Ampso y Caps (Good e Izawa, 1972).

Cuando se utilizó azocoll como sustrato, según la técnica descripta en 3.4.3., la escala de pH cubierta fue mayor: desde 4,0 hasta 11,0 , con intervalos de 0,5 unidad de $\mathrm{pH}$, empleando para ello los buffers antes citados, más ácido acético-acetato de sodio $0,01 \mathrm{M}$ para el intervalo de $\mathrm{pH} 4,0-5,5$. 


\subsection{Efecto de la fuerza iónica sobre la actividad proteolítica}

La actividad de la mayoría de las enzimas no se ve afectada a valores de fuerza iónica bajos, pero disminuye cuando la concentración de sal se incrementa por encima de 0,2 $\mathrm{M}$ (Scopes, 1984). En consecuencia se determinó la actividad proteolítica de las preparaciones crudas sobre azocoll en agua destilada con el agregado de cantidades crecientes de $\mathrm{NaCl}$, hasta llegar a una concentración máxima de 0,3 M.

\subsection{Estabilidad en el rango de pH de mayor actividad proteolítica}

Teniendo en cuenta la posibilidad de utilización de la enzima en procesos industriales, se consideró ventajoso conocer el comportamiento de la preparación enzimática durante períodos más prolongados que los utilizados en las experiencias habituales de laboratorio, dentro del rango de pH de mayor actividad caseinolítica. El experimento se llevó a cabo manteniendo muestras de extracto crudo durante $20,40,80$ y 120 minutos a $37^{\circ} \mathrm{C}$ y a pH 8,0, 8,9 y 10,4, utilizando los buffers Taps, Ampso y Caps (Good e Izawa, 1972). Luego de cada incubación se determinó la actividad residual sobre azocoll de la manera indicada en el punto 3.4.3.

\subsection{Estabilidad térmica}

A fin de estudiar el efecto de la temperatura sobre la actividad proteolítica de las preparaciones enzimáticas, las mismas fueron incubadas durante $0,5,10,20,40,60,90$ y 120 minutos a $37^{\circ} \mathrm{C}, 45^{\circ} \mathrm{C}, 55^{\circ} \mathrm{C}, 60^{\circ} \mathrm{C}$ y $70^{\circ} \mathrm{C}$, a $\mathrm{pH} 8$. Finalizado el período de incubación, las muestras fueron mantenidas en un baño de hielo hasta que se midió la actividad caseinolítica residual. Las determinaciones fueron realizadas a los dos minutos, a cada una de las temperaturas, de acuerdo a la técnica descripta en 3.4.1. 


\subsection{Efecto de activadores e inhibidores}

Con el objeto de determinar a qué grupo pertenece la proteasa en estudio, según los tipos mecanísticos propuestos por Barrett y Rawlings (1991), las preparaciones enzimáticas fueron incubadas durante 10 y 30 minutos a $37^{\circ} \mathrm{C}$ con EDTA (1 y $5 \mathrm{mM}$ ), cisteína $(5$ y 10 $\mathrm{mM}$ ), cloruro mercúrico (1 y $0,1 \mathrm{mM})$, cloruro de calcio (1 y $0,1 \mathrm{mM})$, PMSF (1 mM y 10 $\mathrm{mM})$, iodoacetato de sodio $(0,1$ y $0,01 \mathrm{mM})$ y aprotinina (10 y $30 \mathrm{mM})$.

Dado que el PMSF inhibe tanto a proteinasas cisteínicas como serínicas, aunque en el primer caso la inhibición se revierte por el agregado de tioles reductores (Salvesen y Nagase, 1989), las muestras se preincubaron con PMSF durante 10 y 30 minutos a $37^{\circ} \mathrm{C}$ y luego se determinó la actividad con y sin tratamiento previo con cisteína $12 \mathrm{mM}$. Finalizada la incubación, en todos los casos se determinó la actividad caseinolítica residual como se describe en 3.4.1.

\subsection{Fraccionamiento acetónico}

Si bien la centrifugación de la suspensión de látex (3.3.) asegura la remoción de gomas y otros materiales insolubles, permanecen en la solución pigmentos y glúcidos solubles que es conveniente eliminar para facilitar la aplicación de técnicas cromatográficas de purificación y para evitar que los pigmentos (flavonoides) reaccionen en sus formas oxidadas con las proteínas, inactivándolas (Loomis \& Battaile, 1966). En consecuencia se adoptó el esquema de fraccionamiento acetónico que ilustra el diagrama.

La acetona $\left(-20^{\circ} \mathrm{C}\right)$ se agregó gota a gota y con agitación suave, manteniendo la temperatura de la mezcla a $4^{\circ} \mathrm{C}$, a efectos de minimizar la desnaturalización. La suspensión obtenida en cada caso fue dejada en reposo durante 10 minutos a $-20^{\circ} \mathrm{C}$ y luego centrifugada a $16.000 \mathrm{~g}$ durante 15 minutos a $4^{\circ} \mathrm{C}$. Los precipitados fueron redisueltos en buffer fosfatos $0,1 \mathrm{M}$ de $\mathrm{pH} \mathrm{7,0} \mathrm{y} \mathrm{en} \mathrm{las} \mathrm{soluciones} \mathrm{obtenidas} \mathrm{se} \mathrm{determinó} \mathrm{la} \mathrm{actividad} \mathrm{proteolítica}$ remanente, el contenido de proteínas y de hidratos de carbono tal como se indicó en 3.4.1., 3.6. y 3.7., respectivamente. 


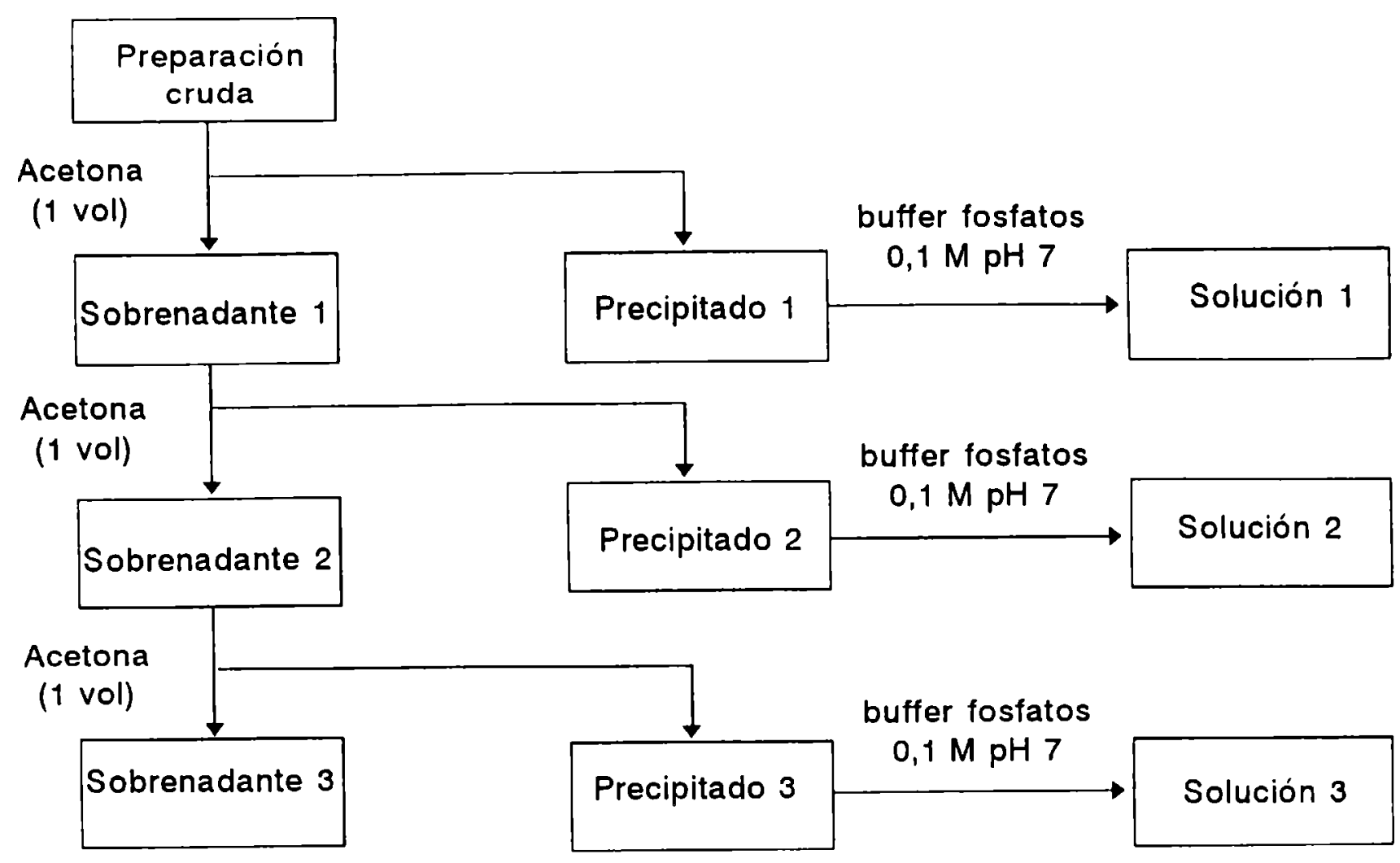

Diagrama de purificación

\subsection{Ensayos de autodigestión}

La aplicación de un esquema de purificación a las preparaciones crudas hace que las soluciones resulten enriquecidas en proteasas y en consecuencia se favorece la tendencia a la autodigestión de las mismas. Para conocer el comportamiento en este sentido de la enzima en estudio, se determinó la actividad caseinolítica residual de muestras parcialmente purificadas.

El precipitado acetónico redisuelto en buffer Tris- $\mathrm{HCl} 50 \mathrm{mM}$ de $\mathrm{pH} 8,0$ se dividió en alícuotas que fueron mantenidas a temperatura ambiente $\left(20^{\circ} \mathrm{C}\right)$ durante $1,3,7$ y 24 horas. De cada alícuota se tomaron muestras para determinar actividad caseinolítica según el protocolo descripto en 3.4.1. y realizar el correspondiente análisis electroforético como se indica más adelante (3.19.). 


\subsection{Cromatografía de intercambio aniónico.}

Con el objeto de resolver la mezcla de proteínas presente en el precipitado acetónico se recurrió a la cromatografía de intercambio iónico, técnica muy utilizada para la separación de macromoléculas biológicas por su alta capacidad, buena resolución, bajo costo y por la ventaja adicional de concentrar las soluciones proteicas.

Dado que la mayoría de las proteínas posee un pI menor o igual a 7, se optó por comenzar practicando una cromatografía de intercambio aniónico a pH 8. El experimento se llevó a cabo en una cámara fría $\left(4^{\circ} \mathrm{C}\right)$ empleando una columna $(1,5 \times 30 \mathrm{~cm})$ de DEAESepharose Fast Flow equilibrada con buffer Tris-HCl $50 \mathrm{mM}$ de $\mathrm{pH}$ 8,0. Luego de sembrar la muestra proveniente de la precipitación acetónica -redisuelta también en buffer Tris- $\mathrm{HCl}$ $50 \mathrm{mM}$ de $\mathrm{pH} 8,0$ - y después de lavar la columna con $60 \mathrm{ml}$ de este buffer, las proteínas retenidas fueron eluídas en una primera etapa con $200 \mathrm{ml}$ de un gradiente lineal de cloruro de sodio $(0,0-1,0 \mathrm{M})$ en el buffer de partida. Para lograr una mejor resolución la pendiente del gradiente fue modificada sucesivamente hasta llegar a los valores de $0-0,25 \mathrm{M}$, que permiten una adecuada separación de las fracciones activas. La velocidad de corrida en todos los casos fue de $8 \mathrm{~cm}^{3} \cdot \mathrm{h}^{-1}$.

\subsection{Diafiltración de la fracción no retenida por el intercambiador aniónico}

La fracción no retenida por el intercambiador aniónico debió ser sometida a un cambio de buffer, reemplazando al Tris- $\mathrm{HCl} 50 \mathrm{mM}$ de $\mathrm{pH} 8,0$ por fosfato de sodio $10 \mathrm{mM}$ de $\mathrm{pH} 7,5$, antes de su siembra en la columna del intercambiador catiónico. Para tal fin se utilizó un equipo Amicon 8050 provisto de una membrana YM 10, que permite el pasaje de solutos de peso molecular inferior a $10 \mathrm{kD}$.

Una alícuota $(10 \mathrm{ml})$ de la fracción no retenida fue diluida hasta $50 \mathrm{ml}$ con el nuevo buffer y colocada en la celda de ultrafiltración, la que se mantuvo dentro de un baño de hielo. Por aplicación de presión de nitrógeno se llevó la muestra nuevamente a $10 \mathrm{ml}$, repitiendo la operación dos veces más, con lo que en la práctica se logra el cambio casi total del buffer inicial. 


\subsection{Cromatografía de intercambio catiónico.}

En una primera etapa se intentó purificar la fracción no retenida por el intercambiador aniónico haciéndola pasar a través de una columna de intercambio catiónico (CM-Sepharose Fast Flow) equilibrada con el mismo buffer en el que se encontraba la muestra (Tris- $\mathrm{HCl} 50$ $\mathrm{mM}$ de $\mathrm{pH} 8,0$ ), pero la mayor parte de las proteínas no fueron retenidas, sugiriendo la necesidad de un cambio en el $\mathrm{pH}$ y/o en la fuerza iónica.

Luego de probar distintas variantes, finalmente se optó por el buffer fosfato de sodio $10 \mathrm{mM}$ de pH 7,5. La fracción no retenida en el intercambiador aniónico se equilibró con el nuevo buffer por diafiltración (3.17.) y se sembró en una columna $(1,5 \times 30 \mathrm{~cm})$ de CMSepharose Fast Flow, equilibrada con el buffer elegido. Luego de lavar la columna con 60 $\mathrm{ml}$ del buffer de partida, se llevó a cabo la elución con $200 \mathrm{ml}$ de un gradiente lineal de cloruro de sodio (0,0-1,0 M) en el mismo buffer. Para lograr una mejor resolución la pendiente del gradiente fue modificada sucesivamente hasta llegar a un gradiente 0,0-0,45 M. Las experiencias se llevaron a cabo en cámara fría $\left(4^{\circ} \mathrm{C}\right)$ y la velocidad de corrida en todos los casos fue de $8 \mathrm{~cm}^{3} \cdot \mathrm{h}^{-1}$.

\subsection{Electroforesis en gradiente de poliacrilamida (Hames, 1981)}

\subsubsection{Preparación de las muestras.}

\subsubsection{Hidrolizados de soja.}

El material proveniente de la hidrólisis parcial de las proteínas contenidas en los concentrados de soja fue sometido a un tratamiento previo de solubilización. Para ello se mezclaron $0,3 \mathrm{ml}$ de cada una de las muestras con $2,7 \mathrm{ml}$ de un buffer extractante (Tris- $\mathrm{HCl}$ $0,1 \mathrm{M}$ de $\mathrm{pH} 8$, conteniendo urea $9 \mathrm{M}$ y $1,1 \%$ de SDS) y se agitaron mediante agitador magnético durante una hora a temperatura ambiente. Las suspensiones se centrifugaron durante 5 minutos a $16.000 \mathrm{~g}$, tomándose luego $0,5 \mathrm{ml}$ de cada sobrenadante que se mezclaron con $0,5 \mathrm{ml}$ de buffer de muestra y se llevaron a ebullición durante 3 minutos. Las 
sembradas en un gel de poliacrilamida en gradiente (6,5-20\%). La estimación de los pesos moleculares se realizó por comparación con proteínas patrones de bajo peso molecular (MWSDS-70L kit, Sigma).

\begin{tabular}{lc}
\hline Proteína & $\begin{array}{l}\text { Peso molecular } \\
\text { aproximado (kD) }\end{array}$ \\
\hline Albúmina bovina & 66,0 \\
Albúmina de huevo & 45,0 \\
Gliceraldehido 3-fosfato & 36,0 \\
deshidrogenasa (subunidad) & 29,0 \\
Anlidrasa carbónica & 24,0 \\
Tripsinógeno & 20,1 \\
Factor inhibidor de tripsina & 14,2 \\
$\alpha$-lactoalbúmina &
\end{tabular}

\subsubsection{Ensayos de autodigestión.}

Las muestras correspondientes a los ensayos de autodigestión fueron precipitadas con 3 volúmenes acetona, redisueltas en buffer de muestra, llevadas a ebullición durante 3 minutos, centrifugadas a $16.000 \mathrm{~g}$ durante 15 minutos y finalmente sembradas en un gel de poliacrilamida en gradiente (8-20\%). Los pesos moleculares de los productos de hidrólisis fueron estimados por comparación con los patrones proteicos antes mencionados.

La solución buffer utilizada en la preparación de las muestras provenientes de los hidrolizados de soja y de los ensayos de autodigestión tiene la siguiente composición:

Buffer de muestra

$\begin{array}{lc}\text { Glicerol } & 10 \mathrm{ml} \\ \text { SDS } & 2 \mathrm{~g} \\ \text { Mercaptoetanol } & 5 \mathrm{ml} \\ \text { Azul de bromofenol } & 2 \mathrm{mg} \\ \text { Buffer Tris-ClH 3M, pH 8,8 c.s.p. } & 100 \mathrm{ml}\end{array}$




\subsubsection{Preparación de los geles.}

Los geles se moldearon empleando el soporte provisto a tal efecto con el equipo MiniProtean II (Bio-Rad). Los gradientes de poliacrilamida se obtuvieron mezclando cantidades iguales de las mezclas polimerizantes con un formador de gradientes (modelo 385, Bio-Rad) y una bomba peristáltica (modelo P-1, Pharmacia). En los geles resultantes $(7 \mathrm{~cm} \mathrm{x} 8 \mathrm{~cm} \mathrm{x}$ $75 \mathrm{~mm}$ ) la concentración de poliacrilamida se incrementa en forma lineal desde la zona de siembra hacia el fondo de la placa.

Las soluciones de poliacrilamida utilizadas para la obtención de los geles en gradiente se prepararon de acuerdo a las fórmulas que se indican a continuación:

Solución de poliacrilamida al $6,5 \%$

$\begin{array}{lr}\text { Acrilanida-bisacrilamida }(30: 0,8) & 1,3 \mathrm{ml} \\ \text { Buffer Tris-ClH } 3 \mathrm{M}, \mathrm{pH} 8,8 & 750 \mu \mathrm{l} \\ \text { TEMED } & 5 \mu \mathrm{l} \\ \text { Persulfato de sodio al 5\% } & 25 \mu \mathrm{l} \\ \text { Agua c.s.p. } & 6 \mathrm{ml}\end{array}$

Solución de poliacrilamida al $8 \%$

$\begin{array}{lr}\text { Acrilamida-bisacrilamida }(30: 0,8) & 1,6 \mathrm{ml} \\ \text { Buffer Tris-ClH } 3 \mathrm{M}, \mathrm{pH} 8,8 & 750 \mu \mathrm{l} \\ \text { TEMED } & 5 \mu \mathrm{l} \\ \text { Persulfato de sodio al 5\% } & 25 \mu \mathrm{l} \\ \text { Agua c.s.p. } & 6 \mathrm{ml}\end{array}$

Solución de poliacrilamida al $\mathbf{2 0 \%}$

$\begin{array}{lr}\text { Acrilamida-bisacrilamida }(30: 0,8) & 4 \mathrm{ml} \\ \text { Sacarosa } & 900 \mathrm{mg} \\ \text { Buffer Tris-CIH 3 M, pH 8,8 } & 750 \mu \mathrm{l} \\ \text { TEMED } & 5 \mu \mathrm{l} \\ \text { Persulfato de sodio al 5\% } & 12 \mu \mathrm{l} \\ \text { Agua c.s.p. } & 6 \mathrm{ml}\end{array}$

Las cantidades indicadas son las necesarias para preparar dos placas. 


\subsubsection{Aplicación de las muestras}

Las muestras se aplicaron bajo buffer con jeringa Hamilton (volúmenes de siembra: $10-20 \mu \mathrm{l})$.

\subsubsection{Condiciones de corrida}

La electroforesis se desarrolló en un equipo Mini-Protean II Dual Slab Cell (Bio Rad) durante 60 minutos a corriente constante $(40 \mathrm{~mA})$, empleando el siguiente buffer de reservorio:

\section{Buffer de reservorio}

$\begin{array}{ll}\text { Tris } & 0,050 \mathrm{M} \\ \text { Glicina } & 0,384 \mathrm{M} \\ \text { SDS } & 0,1 \%\end{array}$

$(\mathrm{pH} 8,3)$

\subsubsection{Fijación y coloración}

Una vez completada la corrida, los geles fueron sumergidos durante 12 horas en la solución colorante, la que actúa también como fijadora, y luego sometidos a sucesivos lavados con solución decolorante hasta la obtención de un fondo incoloro. A continuación se indica la composición de las soluciones mencionadas:

\section{Solución colorante}

Acido acético glacial

Metanol

Coomassie brilliant blue R-250

Agua destilada c.s.p.
$10 \mathrm{ml}$

$40 \mathrm{ml}$

$100 \mathrm{mg}$

$100 \mathrm{ml}$

(la solución se filtra antes de usar) 


\section{Solución decolorante}

Acido acético glacial

Metanol

Agua destilada c.s.p.
$10 \mathrm{ml}$

$25 \mathrm{ml}$

$100 \mathrm{ml}$

\subsection{Electroforesis discontinua (Laemmli, 1970)}

\subsubsection{Preparación de las muestras.}

Las muestras correspondientes a las fracciones proteolíticamente activas obtenidas por cromatografía de intercambio iónico fueron precipitadas con tres volúmenes de acetona a los efectos de su concentración. Los precipitados acetónicos fueron redisueltos en buffer de muestra, llevados a ebullición durante 3 minutos y centrifugados a $16.000 \mathrm{~g}$.

\subsubsection{Preparación de los geles.}

Los geles se moldearon dentro de placas de vidrio de $10 \mathrm{~cm}$ por $15 \mathrm{~cm}$, separadas por espaciadores de 1,2 $\mathrm{mm}$ de espesor y selladas en sus bordes laterales e inferior con una solución de agar al $2 \%$. En un primer paso se prepara el gel de resolución y luego de que éste polimerice se hace lo propio con el gel de "stacking". La composición de las soluciones necesarias para la preparación de ambos geles se describe a continuación:

\section{Solución de poliacrilamida al $10 \%$}

$\begin{array}{lr}\text { Acrilamida-bisacrilamida }(30: 0,8) & 5 \mathrm{ml} \\ \text { Buffer Tris-CIH 3 M, pH 8,8 } & 1,88 \mathrm{ml} \\ \text { SDS 10\% } & 0,15 \mathrm{ml} \\ \text { TEMED } & 7 \mu l \\ \text { Persulfato de sodio al 1,5\% } & 0,75 \mathrm{ml} \\ \text { Agua c.s.p. } & 15 \mathrm{ml}\end{array}$




\begin{tabular}{lr}
\multicolumn{2}{c}{ Solución de "stacking" } \\
Acrilamida-bisacrilanida (30:0,8) & $1,16 \mathrm{ml}$ \\
Buffer Tris-ClH 0,5 M, pH 6,8 & $0,87 \mathrm{ml}$ \\
SDS 10\% & $0,07 \mathrm{ml}$ \\
TEMED & $4 \mu \mathrm{l}$ \\
Persulfato de sodio al 1,5 & $0,35 \mathrm{ml}$ \\
Agua c.s.p. & $7 \mathrm{ml}$
\end{tabular}

\subsubsection{Aplicación de las muestras}

Las muestras se aplicaron bajo buffer con jeringa Hamilton. Los volúmenes de siembra fueron de $12 \mu \mathrm{l}$ para los patrones de peso molecular y de $25 \mu \mathrm{l}$ en el caso de las fracciones purificadas.

\subsubsection{Condiciones de corrida}

La electroforesis se desarrolló en un aparato tipo Studier (Hames, 1981), construido en nuestro laboratorio. La corrida se llevó a cabo durante 3 horas con una intensidad de corriente constante de $20 \mathrm{~mA}$ mientras se produce el apilado ("stacking"), incrementándose hasta $30 \mathrm{~mA}$ durante la corrida. El buffer de reservorio utilizado fue el siguiente:

Buffer de reservorio

$\begin{array}{ll}\text { Tris } & 0,050 \mathrm{M} \\ \text { Glicina } & 0,384 \mathrm{M} \\ \text { SDS } & 0,1 \%\end{array}$

$(\mathrm{pH} 8,3)$

\subsubsection{Fijación y coloración}

Estas etapas se desarrollaron como fue indicado en 3.19.5 


\subsubsection{Estimación de los pesos moleculares}

Para la determinación de los pesos moleculares de las distintas especies proteicas por electroforesis en geles de poliacrilamida se utilizó como estándar una mezcla de proteínas de bajo peso molecular (LMW kit, Pharmacia).

\begin{tabular}{lc}
\hline Proteína & $\begin{array}{c}\text { Peso molecular } \\
\text { aproximado }(\mathrm{kD})\end{array}$ \\
\hline Fosforilasa b & 94,0 \\
Albúmina & 67,0 \\
Ovalbúmina & 43,0 \\
Anhidrasa carbónica & 30,0 \\
Inhibidor de tripsina & 20,1 \\
$\alpha$-lactalbúmina & 14,4
\end{tabular}

La determinación de los pesos moleculares se realizó en base a una curva de calibración obtenida al graficar los logaritmos de los pesos moleculares de las proteínas estándar en función de la movilidad relativa de cada especie proteica.

\subsection{Isoelectroenfoque}

Se realizó empleando el equipo Mini IEF Cell (Modelo 111, Bio Rad).

\subsubsection{Preparación de las muestras.}

Las muestras purificadas por intercambio iónico se concentraron y desionizaron por precipitación con 3 volúmenes de acetona, el sobrenadante se eliminó por centrifugación y el precipitado fue redisuelto con agua bidestilada. Dicho tratamiento se repitió dos veces. 


\subsubsection{Preparación de los geles.}

Para ello se empleó la bandeja formadora de geles del mencionado equipo. En la misma se pueden disponer hasta dos placas de vidrio soportando las correspondientes películas plásticas sobre las que se deja polimerizar el gel de poliacrilamida, preparado con una solución de la siguiente composición:

\section{Solución de poliacrilamida al $\mathbf{1 0 \%}$}

$\begin{array}{ll}\text { Acrilamida-bisacrilamida }(25 \% \mathrm{~T}, 3 \% \mathrm{C}) & 2,0 \mathrm{ml} \\ \text { Glicerol }(25 \% \mathrm{p} / \mathrm{v}) & 2,0 \mathrm{ml} \\ \text { Anfolitos (Phamalyte 3-10) } & 0,5 \mathrm{ml} \\ \text { Agua } & 5,5 \mathrm{ml}\end{array}$

La solución anterior se desgasificó a través de una bomba de vacío durante 15 minutos, y luego se le adicionaron los siguientes reactivos para iniciar la polimerización:

$\begin{array}{lr}\text { TEMED } & 3 \mu \mathrm{l} \\ \text { persulfato de sodio al } 10 \% \mathrm{p} / \mathrm{v} & 60 \mu \mathrm{l}\end{array}$

La mezcla fue depositada con pipeta entre el plato de vidrio y la bandeja formadora de geles y el conjunto se mantuvo durante 12 horas a temperatura ambiente para obtener la polimerización total.

Los geles se removieron de la bandeja con ayuda de una espátula delgada.

\subsubsection{Aplicación de las muestras}

Las muestras se aplicaron con jeringa Hamilton (volúmenes de siembra: $1-5 \mu \mathrm{l}$ ) y se permitió que difundieran dentro del gel durante 5 minutos antes de iniciar la corrida.

\subsubsection{Desarrollo del isoelectroenfoque}

Los geles fueron depositados sobre los electrodos de grafito previamente humedecidos de la celda de isoelectroenfoque, la que se cerró herméticamente y se conectó a la fuente de 
poder. El enfoque fue llevado a cabo en tres etapas, a voltaje constante: $100 \mathrm{~V}$ durante 15 minutos, $200 \mathrm{~V}$ durante 15 minutos y $450 \mathrm{~V}$ durante 60 minutos.

\subsubsection{Fijación}

Una vez completada la corrida, los geles separados de la placa de vidrio fueron sumergidos durante 30 minutos en la siguiente solución fijadora

\section{Solución fijadora}

Acido sulfosalicílico

Metanol

Acido tricloroacético

Agua c.s.p.
$4 \mathrm{~g}$

$30 \mathrm{ml}$

$12,5 \mathrm{~g}$

$100 \mathrm{nl}$

\subsubsection{Coloración}

Finalizada la etapa anterior los geles fueron tratados durante dos horas con la solución colorante y luego decolorados por tres lavados sucesivos con solución decolorante I, seguidos de un último lavado con solución decolorante II hasta la obtención de un fondo incoloro. La composición de las mencionadas soluciones se indica a continuación:

\section{Solución colorante}

\begin{tabular}{lr} 
Acido acético glacial & $10 \mathrm{ml}$ \\
Etanol & $27 \mathrm{ml}$ \\
Coomassie Brilliant Blue R-250 & $40 \mathrm{mg}$ \\
$\mathrm{CuSO}_{4}$ & $500 \mathrm{mg}$ \\
Agua c.s.p. & $100 \mathrm{ml}$ \\
\multicolumn{2}{c}{ (la solución se filtra antes de usar) }
\end{tabular}

Solución decolorante I

$\begin{array}{lr}\text { Acido acético glacial } & 7 \mathrm{ml} \\ \text { Etanol } & 12 \mathrm{ml} \\ \mathrm{CuSO}_{4} & 500 \mathrm{mg} \\ \text { Agua c.s.p. } & 100 \mathrm{ml}\end{array}$




\section{Solución decolorante II}

Acido acético glacial

$7 \mathrm{ml}$

Etanol

$12 \mathrm{ml}$

Agua c.s.p.

$100 \mathrm{ml}$

\subsubsection{Estimación de los puntos isoeléctricos}

Para la determinación de los puntos isoeléctricos ( $\mathrm{pl}$ ) por isoelectroenfoque de las distintas especies proteicas se utilizó como proteínas estándar una mezcla de proteínas de amplio rango de pI (Broad pI kit, Pharmacia).

\begin{tabular}{lc}
\hline Proteína & pI \\
\hline Amiloglucosidasa & 3,50 \\
Inhibidor de Tripsina & 4,55 \\
B-lactoglobulina A & 5,20 \\
Anhidrasa carbónica B (bovina) & 5,85 \\
Anhidrasa carbónica B (humana) & 6,55 \\
Mioglobina (banda ácida) & 6,85 \\
Mioglobina (banda básica) & 7,35 \\
Lentil lectina (ácida) & 8,15 \\
Lentil lectina (media) & 8,45 \\
Lentil lectina (básica) & 8,65 \\
Tripsinógeno & 9,30
\end{tabular}

La determinación de los valores de pI se realizó mediante una curva de calibración obtenida al graficar los pI de las proteínas estándar en función de la distancia recorrida por la especie proteica de interés, tomando como referencia la posición del cátodo.

\subsection{Zimograma (Westergaar et al., 1980)}

\subsubsection{Preparación de las placas agarosa-caseína}

Las placas de agarosa se prepararon sobre una película de GelBond (Pharmacia) de un tamaño aproximadamente igual al del gel de poliacrilamida. Sobre el lado hidrofílico del film se depositó una solución de agarosa al $1 \%$ en Tris- $\mathrm{HCl} 0,05 \mathrm{M}$ de $\mathrm{pH}$ 
$8,0,\left(0,15 \mathrm{ml} / \mathrm{cm}^{2}\right)$. Una vez polimerizada la agarosa, la placa fue sumergida en una solución de caseína al $1 \%$ en el mismo buffer durante 20 minutos; por último fue enjuagada con agua destilada y se dejó escurrir durante 10 minutos.

\subsubsection{Desarrollo del zimograma}

El gel de poliacrilamida fue dispuesto sobre la placa de agarosa-caseína evitando la formación de burbujas entre las superficies en contacto. El conjunto fue colocado dentro de una cámara húmeda y llevado a estufa a $55^{\circ} \mathrm{C}$ durante 7 minutos.

\subsubsection{Fijación}

Transcurrido el desarrollo del zimograma los geles fueron separados y la placa de agarosa-caseína sumergida durante 60 minutos en la solución fijadora cuya composición se indica a continuación:

\section{Solución fijadora}

Acido acético glacial

Metanol

Agua destilada c.s.p.
$10 \mathrm{ml}$

$45 \mathrm{ml}$

$100 \mathrm{nll}$

\subsubsection{Coloración}

Una vez fijadas las proteínas, la placa de agarosa-caseína fue deshidratada entre papeles de filtro Whatman $3 \mathrm{MM}$ bajo una presión de $7,5 \mathrm{~g} / \mathrm{cm}^{2}$ durante 20 minutos. Luego fue secada con pistola de aire y sumergida durante 10-30 minutos en la siguiente solución colorante: 


\section{Solución colorante}

Coomassie Brilliant Blue R-250

$250 \mathrm{mg}$

Solución fijadora c.s.p.

$100 \mathrm{ml}$

(la solución se filtra antes de usar)

\subsubsection{Decoloración}

Se realizó por inmersión de la placa de agarosa-caseína en la solución fijadora durante 10 minutos y se secó con pistola de aire.

\footnotetext{
Abreviaturas utilizadas en el texto

Ampso = ácido 3-[(1,1-dimetil-2-hidroxietil)amino]-2-hidroxipropan-sulfónico

Caps = ácido 3-(ciclohexilamino)-1-propan-sulfónico

EDTA = ácido etilendiamino-tetra-acético (sal sódica)

Mes = ácido 2-(N-morfolino)-etan-sulfónico

Mops = ácido 3-(N-morfolino)-propan-sulfónico

PMSF = fluoruro de fenilmetilsulfonilo

SDS = dodecilsulfato de sodio

Taps = ácido $\mathrm{N}$-tris-(hidroximetil)-metil-3-aminopropan-sulfónico

TEMED $=\mathrm{N}, \mathrm{N}, \mathrm{N}^{\prime}, \mathrm{N}^{\prime}$-tetranetiletilendiamina

Tris = tris-(hidroximetil)-anninometano
} 


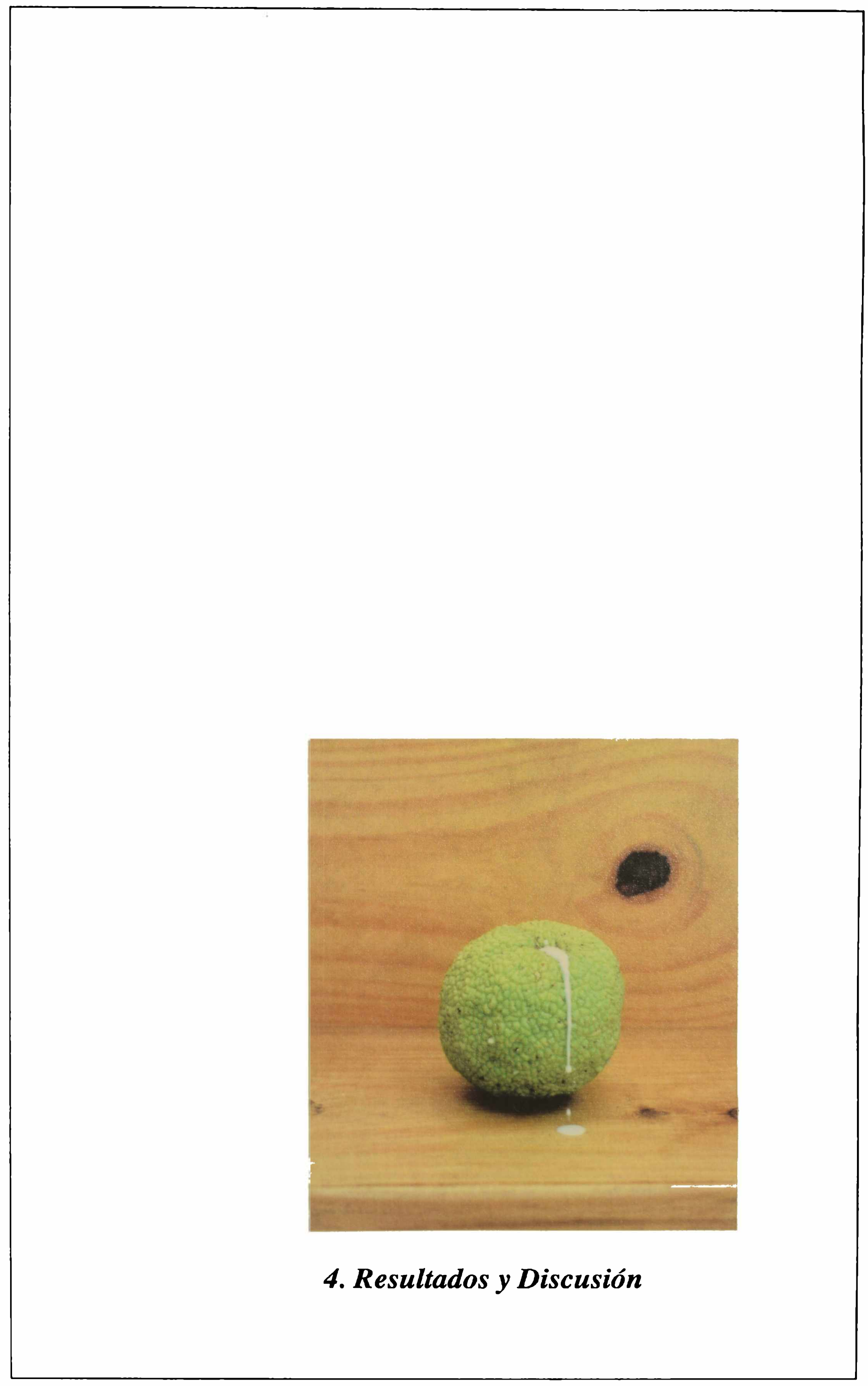




\subsection{Relación entre el grado de madurez de los frutos, la producción de látex y el contenido en proteasas de los mismos}

Para establecer el período óptimo de recolección de los frutos se midieron los siguientes parámetros: peso promedio de los frutos en distintos estadios de maduración, rendimiento en látex y actividad proteolítica específica. En este experimento se utilizaron frutos provenientes de un único ejemplar de Maclura pomifera, recogidos durante el período enero-abril de 1989.

Los resultados presentados en la fig. 4.1. muestran claramente que los frutos con el máximo grado de madurez son los que presentan el mejor rendimiento en látex y que éste posee, además, la mayor actividad específica.

\subsection{Distribución del contenido de látex en frutos de Maclura pomifera}

El rendimiento en látex de frutos obtenidos en su estado óptimo de maduración no resultó ser demasiado variable, como se desprende de los datos contenidos en la Tabla 4.1. y en particular de la fig. 4.2, donde puede apreciarse el grado de dispersión de los valores con respecto a la media. Los valores oscilan entre 0,39 y 0,78 , con una media de $0,51 \mathrm{ml}$ de látex por $100 \mathrm{~g}$ de frutos.

\begin{tabular}{cllcc}
$\begin{array}{c}\text { Muestra } \\
N^{0}\end{array}$ & $\begin{array}{c}\text { Fecha de } \\
\text { recolección }\end{array}$ & $\begin{array}{c}\text { Lugar de } \\
\text { recolección }\end{array}$ & $\begin{array}{c}\text { Número de } \\
\text { frutos }\end{array}$ & $\begin{array}{c}\text { ml látex/ } \\
100 \text { g frutos }\end{array}$ \\
\hline 1 & 14.03 .89 & Villa Elisa & 4 & 0,72 \\
2 & 15.03 .89 & Villa Elisa & 5 & 0,39 \\
3 & 22.03 .89 & Villa Elisa & 11 & 0,60 \\
4 & 28.03 .89 & Villa Elisa & 4 & 0,55 \\
5 & 29.03 .89 & Villa Elisa & 4 & 0,78 \\
6 & 05.04 .89 & Pque. Pereyra Iraola & 6 & 0,66 \\
7 & 06.04 .89 & Pque. Pereyra Iraola & 9 & 0.61 \\
8 & 07.03 .90 & Villa Elisa & 8 & 0,40 \\
9 & 14.03 .90 & Villa Elisa & 3 & 0,58 \\
10 & 09.04 .90 & Villa Elisa & 7 & 0,47 \\
11 & 18.04 .90 & Villa Elisa & 5 & 0,46 \\
12 & 12.04 .91 & Villa Elisa & 4 & 0,39 \\
13 & 12.04 .92 & Villa Elisa & 4 & 0.41 \\
14 & 17.04 .93 & Pque. Pereyra Iraola & 24 & 0,42 \\
15 & 20.04 .94 & Villa Elisa & 4 & 0,53
\end{tabular}

Tabla 4.1. Material vegetal procesado durante el estudio de las proteasas de frutos de Maclura pomifera. 


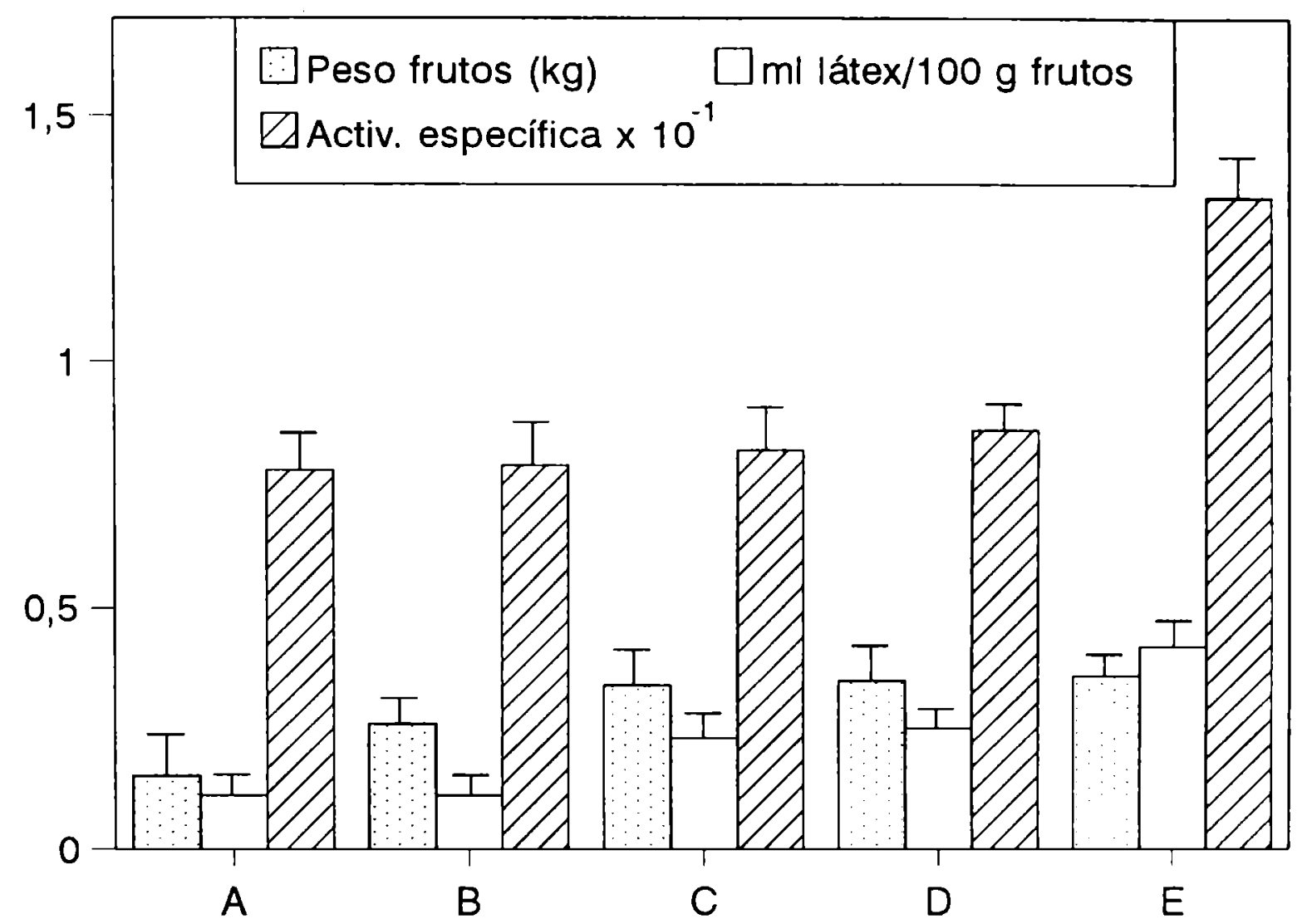

\begin{tabular}{|l|l|l|l|l|l|}
\hline Peso frutos $(\mathrm{kg})$ & 0,15 & 0,26 & 0,34 & 0,35 & 0,36 \\
$\mathrm{ml}$ látex $/ 100 \mathrm{~g}$ frutos & 0,11 & 0,11 & 0,23 & 0,25 & 0,42 \\
Activ. específica $\times 10^{-1}$ & 0,78 & 0,79 & 0,82 & 0,86 & 1,33 \\
\hline
\end{tabular}

Figura 4.1. Relación entre el grado de madurez de los frutos, el peso de los mismos, la producción de látex y el contenido en proteasas. Los estadios de maduración corresponden a senanas contadas a partir del inicio de la floración (A: 15 semanas; B: 19 semanas; C: 22 semanas; D: 25 semanas; E: 30 semanas). Las barras representan la desviación estándar $(\mathrm{n}=5)$. 


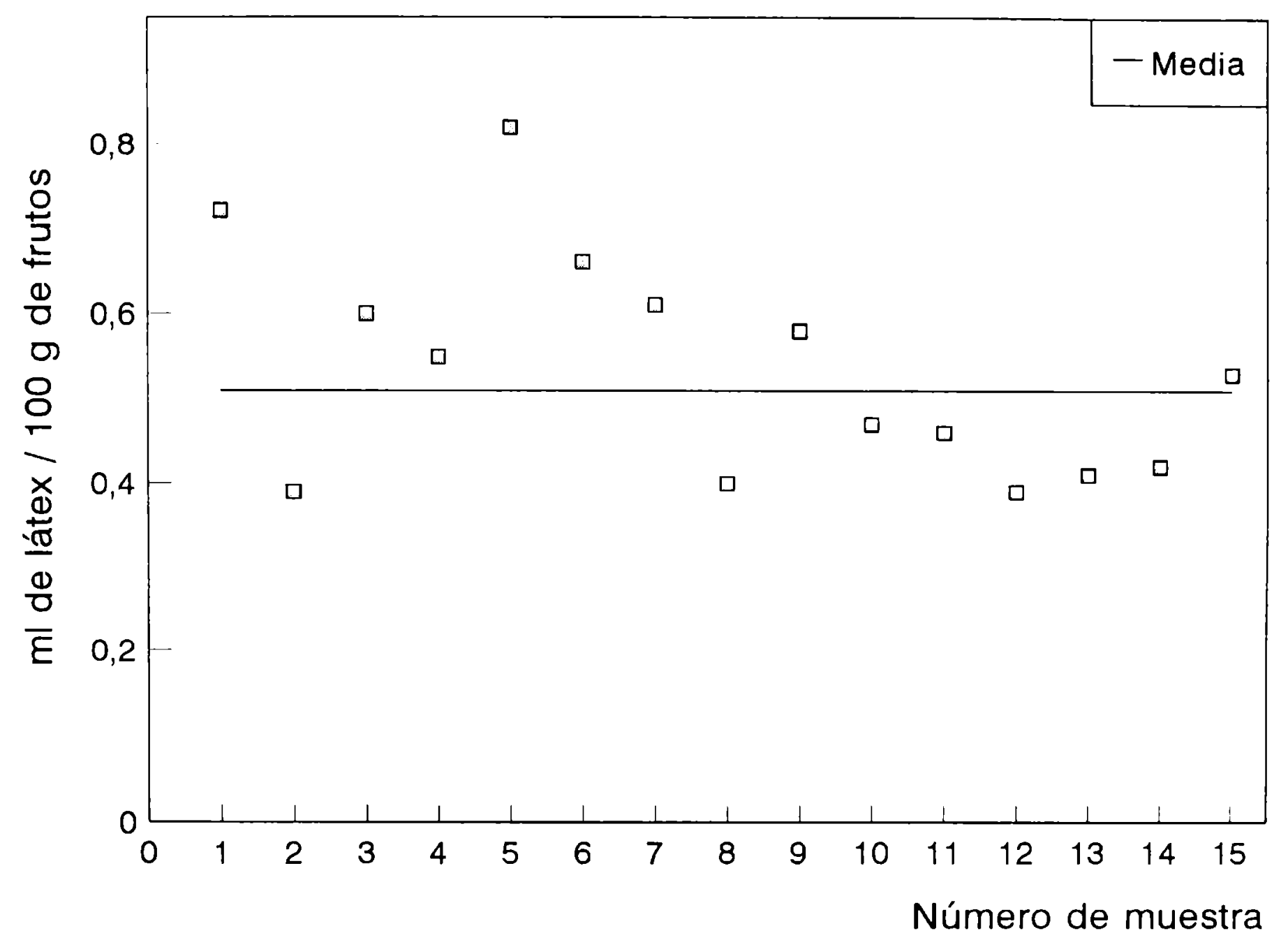

Figura 4.2. Distribución del rendiniento en látex de frutos de Maclura pomifera. La numeración dada a las muestras corresponde al material incluido en la Tabla 4.1. La línea que cruza el gráfico indica el valor medio. 


\subsection{Caracterización de las preparaciones crudas}

\subsubsection{Denominación de las proteasas en estudio}

Como ha ocurrido previamente con otros productos naturales de origen vegetal, la imposición de nombres vulgares a las fitoproteasas no ha podido sustraerse a un cierto grado de anarquía, a pesar de algún intento aislado (Heinicke y Gortner, 1957) por establecer pautas de nomenclatura para los mismos. Así, los nombres triviales de algunas enzimas proteolíticas están basados en el nombre genérico de la especie ("ficina" de Ficus), otros en el epíteto específico ("pingüinina" de Bromelia pinguin L.) o en una contracción del mismo ("papaína" de Carica papaya L.) y algunos en el nombre de la familia o del género tipo ("bromelina", obtenida de Ananas comosus L., familia Bromeliaceae, género tipo Bromelia).

En el caso de las proteasas presentes en el látex de Maclura pomifera (Raf.) Schneid. (Moraceae) y teniendo en cuenta la inexistencia de normas nomenclaturales al respecto, se decidió mantener el nombre propuesto por Tauber (1949), ya que si bien se trata de un estudio muy preliminar, la imposición de un nuevo nombre trivial podría generar innecesarios equívocos. Como sucede con las fitoproteasas más conocidas (papaína, ficina y bromelina), el nombre dado a la enzima en estudio ("pomiferina") se aplica tanto a las preparaciones crudas como a las purificadas.

\subsubsection{Conservación de las preparaciones crudas}

El mantenimiento prolongado de las preparaciones crudas a bajas temperaturas $\left(-20^{\circ} \mathrm{C}\right)$ produce una ligera pérdida de actividad caseinolítica (fig. 4.3.), efecto que se va incrementando con el tiempo, reduciéndose a un $85 \%$ de la actividad inicial luego de permanecer almacenada durante 6 meses en dichas condiciones.

Como ocurrió con otras proteasas vegetales estudiadas en nuestro laboratorio (Priolo et al., 1991), la liofilización resultó ser un procedimiento adecuado para conservar 


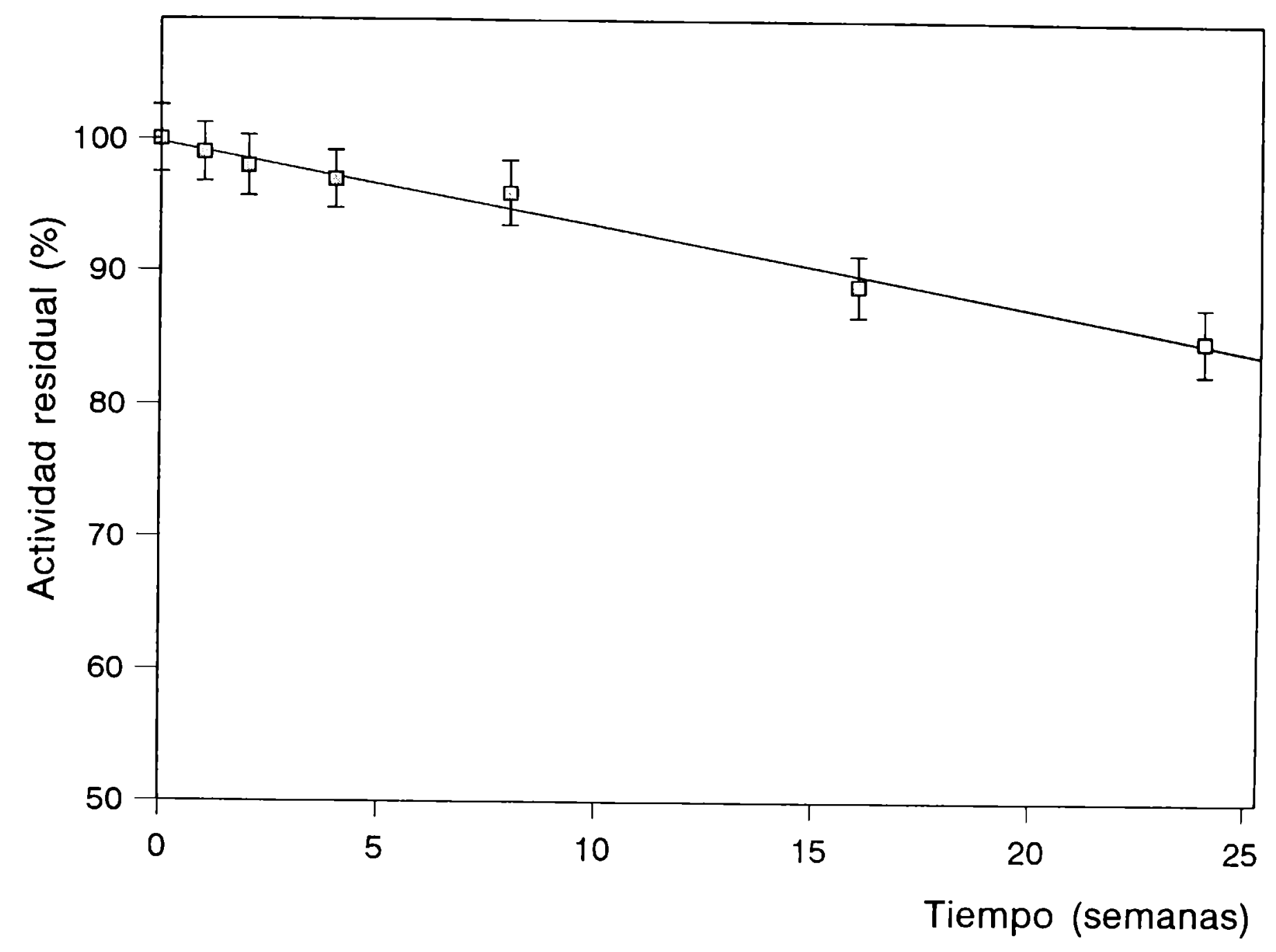

Figura 4.3. Efecto de la baja temperatura $\left(-20^{\circ} \mathrm{C}\right)$ sobre la actividad proteolítica de las preparaciones crudas. Los datos resultan de promediar dos ensayos independientes $(n=5)$. Las barras representan la desviación estándar de los promedios. 
preparaciones crudas de pomiferina, ya que la pérdida de la actividad enzimática luego de redisueltas es mínima ( $2 \pm 0,4 \%$, luego de 6 meses de almacenamiento).

\subsubsection{Efecto del pH sobre la actividad proteolítica}

Las determinaciones se llevaron a cabo empleando alternativamente un sustrato soluble (caseína) y uno insoluble (azocoll). En el primer caso el rango de $\mathrm{pH}$ ensayado fue $6,0-11,0$ y en el segundo $4,0-11,0$.

Los resultados obtenidos se muestran en la fig. 4.4. Cuando se utiliza caseína como sustrato, el rango de mayor actividad proteolítica (actividad relativa superior al $90 \%)$ está ubicado entre pH 9,3 y 10,3, aún cuando la actividad es significativamente elevada (60\% del valor máximo) entre $\mathrm{pH} 7,2$ y 11,2 . A pH inferior a 6,5 la actividad no supera el $40 \%$ del valor máximo, en tanto que hacia el extremo alcalino se observa un brusco descenso a partir de $\mathrm{pH} 10,8$.

En el caso de azocoll el perfil de $\mathrm{pH}$ es similar, aunque se encuentra desplazado ligeramente hacia valores de $\mathrm{pH}$ menos básicos; aquí el rango de máxima actividad enzimática (actividad relativa superior al 90\%) se localiza entre pH 8,2 y 9,3. A pH 4,0 no se manifiesta actividad proteolítica.

El comportamiento de pomiferina a diferentes valores de $\mathrm{pH}$ resulta así coincidente con el de la mayoría de las proteinasas serínicas (Barrett, 1986), en las que la máxima actividad proteolítica se expresa a pH alcalino.

\subsubsection{Efecto de la fuerza iónica sobre la actividad enzimática}

Para establecer en qué medida la fuerza iónica del medio afecta la actividad proteolítica, se sometió a la enzima a concentraciones crecientes de $\mathrm{NaCl}$. Como puede verse en la fig. 4.5., la fuerza iónica no afecta la actividad enzimática a concentraciones iguales o menores a $0,15 \mathrm{M}$, en tanto que si es expuesta a concentraciones salinas mayores 


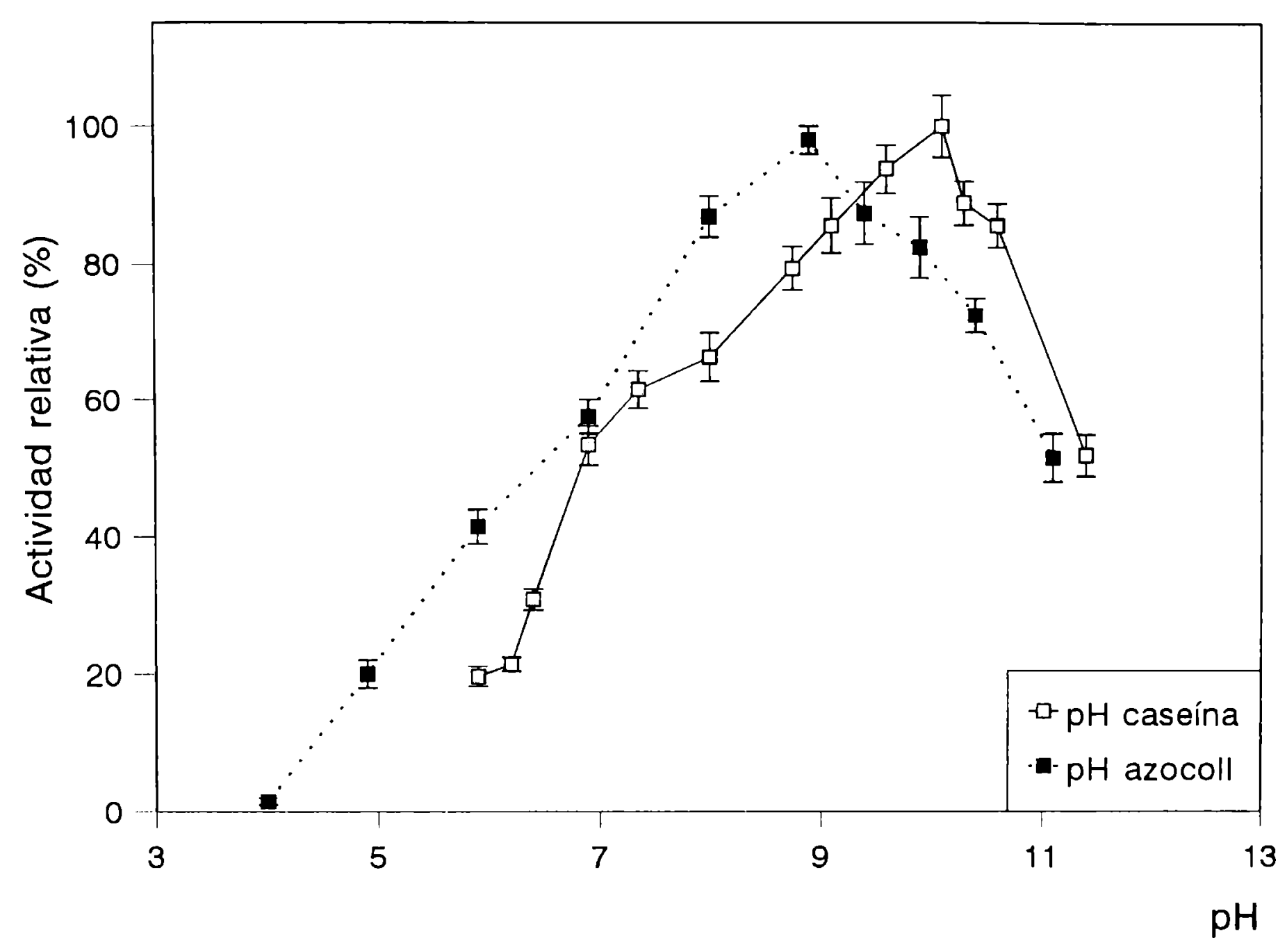

Figura 4.4. Efecto del pH sobre la actividad de las preparaciones crudas frente a caseína y azocoll. Los valores consignados corresponden al $\mathrm{pH}$ de las mezclas de reacción. Los datos para cada sustrato resultan de promediar dos ensayos independientes $(n=5)$. Las barras representan la desviación estándar de los promedios. 


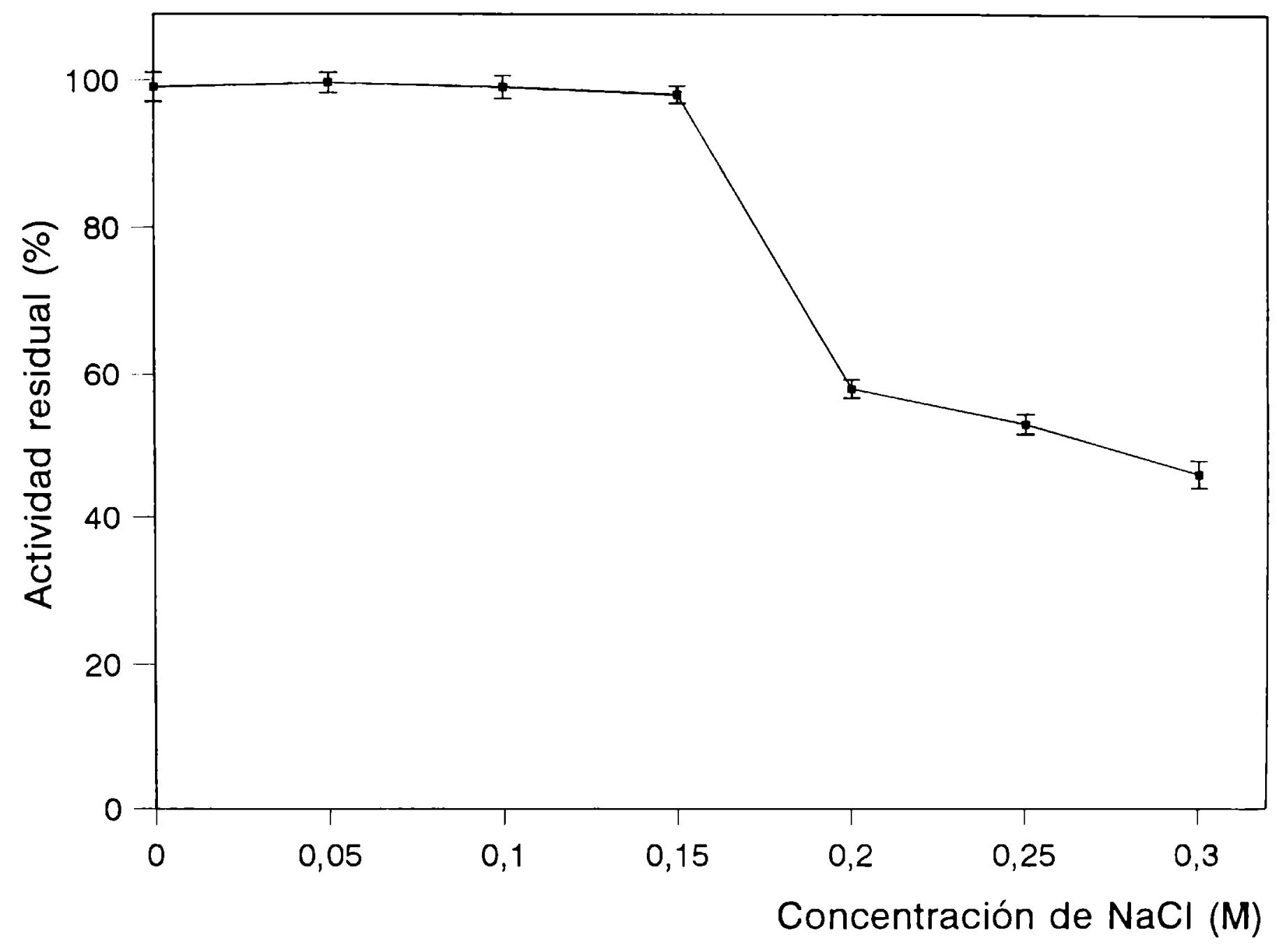

Figura 4.5. Efecto de la fuerza iónica sobre la actividad proteolítica (azocoll) de las preparaciones crudas. Los datos resultan de promediar dos ensayos independientes $(\mathbf{n}=$ 5). Las barras representan la desviación estándar de los promedios. 
se observa un brusco descenso de la misma. Estos resultados se corresponden con el comportamiento de la mayoría de las enzimas solubles (Scopes, 1984).

\subsubsection{Estabilidad de las preparaciones crudas}

Con el doble propósito de efectuar un aporte adicional a la caracterización de las preparaciones crudas y de proporcionar información que resultaría necesaria en el caso de su utilización en procesos industriales, se ensayó la estabilidad de las preparaciones crudas de pomiferina frente al $\mathrm{pH}$ y a la temperatura.

\subsubsection{Estabilidad al pH}

Luego de mantener las preparaciones de pomiferina durante un tiempo máximo de 120 minutos a $37^{\circ} \mathrm{C}$ a los valores de $\mathrm{pH} 8,0,8,9$ y 10,4 , no se detectaron variaciones significativas en la actividad proteolítica (fig. 4.6.). Esta característica resulta sumamente ventajosa a los efectos de la aplicación de la proteasa, ya que permite utilizar la enzima en el rango de $\mathrm{pH}$ correspondiente a su mayor actividad al menos durante dos horas sin que se manifieste pérdida apreciable de su actividad biológica.

\subsubsection{Estabilidad térmica}

En el gráfico presentado en la fig. 4.7. pueden observarse las variaciones que experimenta la actividad caseinolítica a lo largo del tiempo con respecto al valor inicial para cada una de las temperaturas a las que se realizó el ensayo. La actividad caseinolítica prácticamente no sufre cambios luego de mantener la enzima durante dos horas a $37{ }^{\circ} \mathrm{C} o$ a $45^{\circ} \mathrm{C}$ y es aún aceptablemente elevada $(88 \%$ del valor inicial) luego de incubar la enzima a $55^{\circ} \mathrm{C}$ durante el mismo período. A $60^{\circ} \mathrm{C}$ la actividad residual decrece ligeramente con el tiempo, reteniendo el $65 \%$ de la misma al cabo de dos horas de 


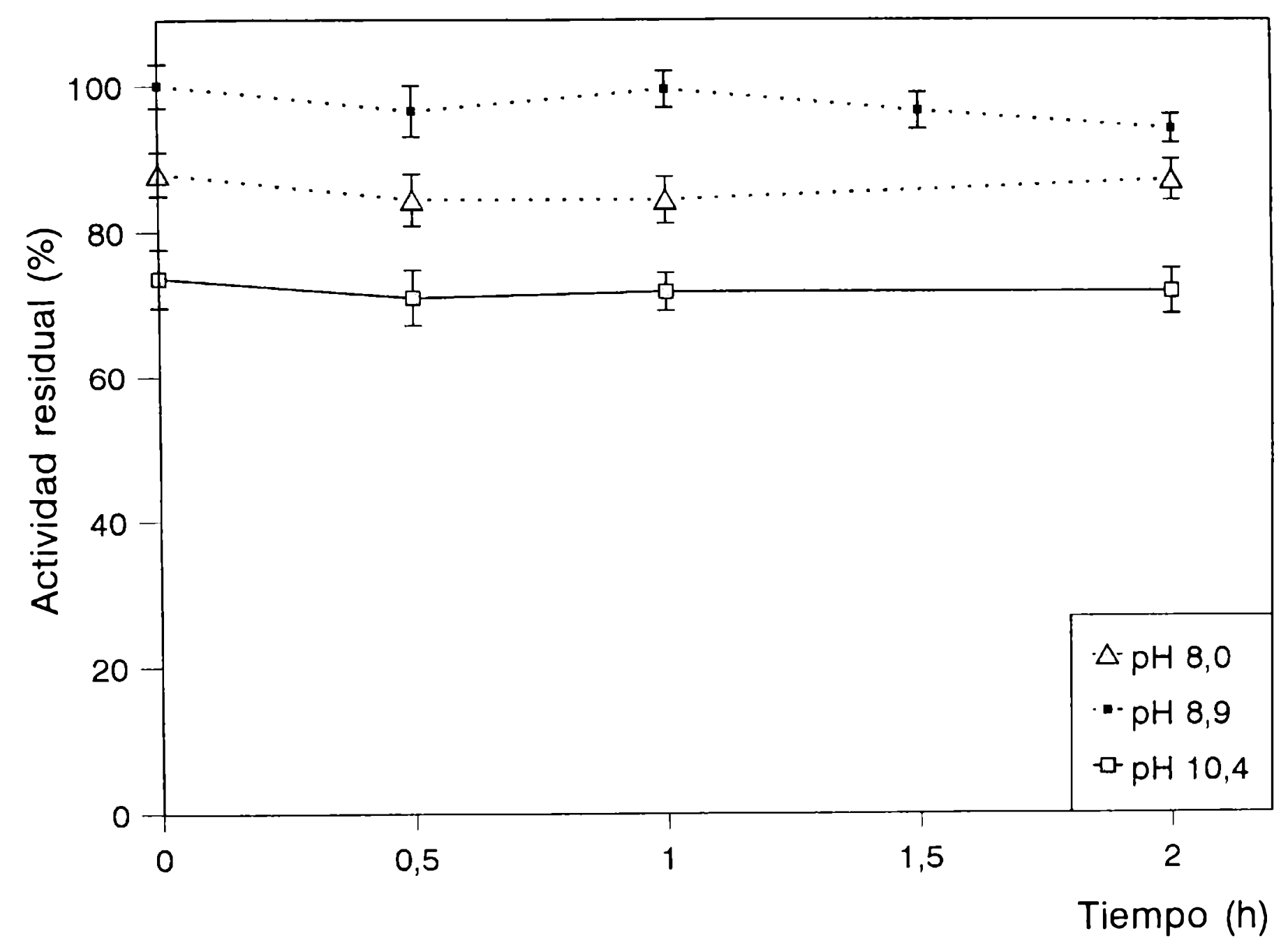

Figura 4.6. Estabilidad de pomiferina a valores de pH pertenecientes al rango de mayor actividad. Luego de cada incubación se determinó la actividad residual sobre azocoll de la manera indicada en el punto 3.4.3. Los datos resultan de promediar dos ensayos independientes $(n=5)$. Las barras representan la desviación estándar de los promedios. 


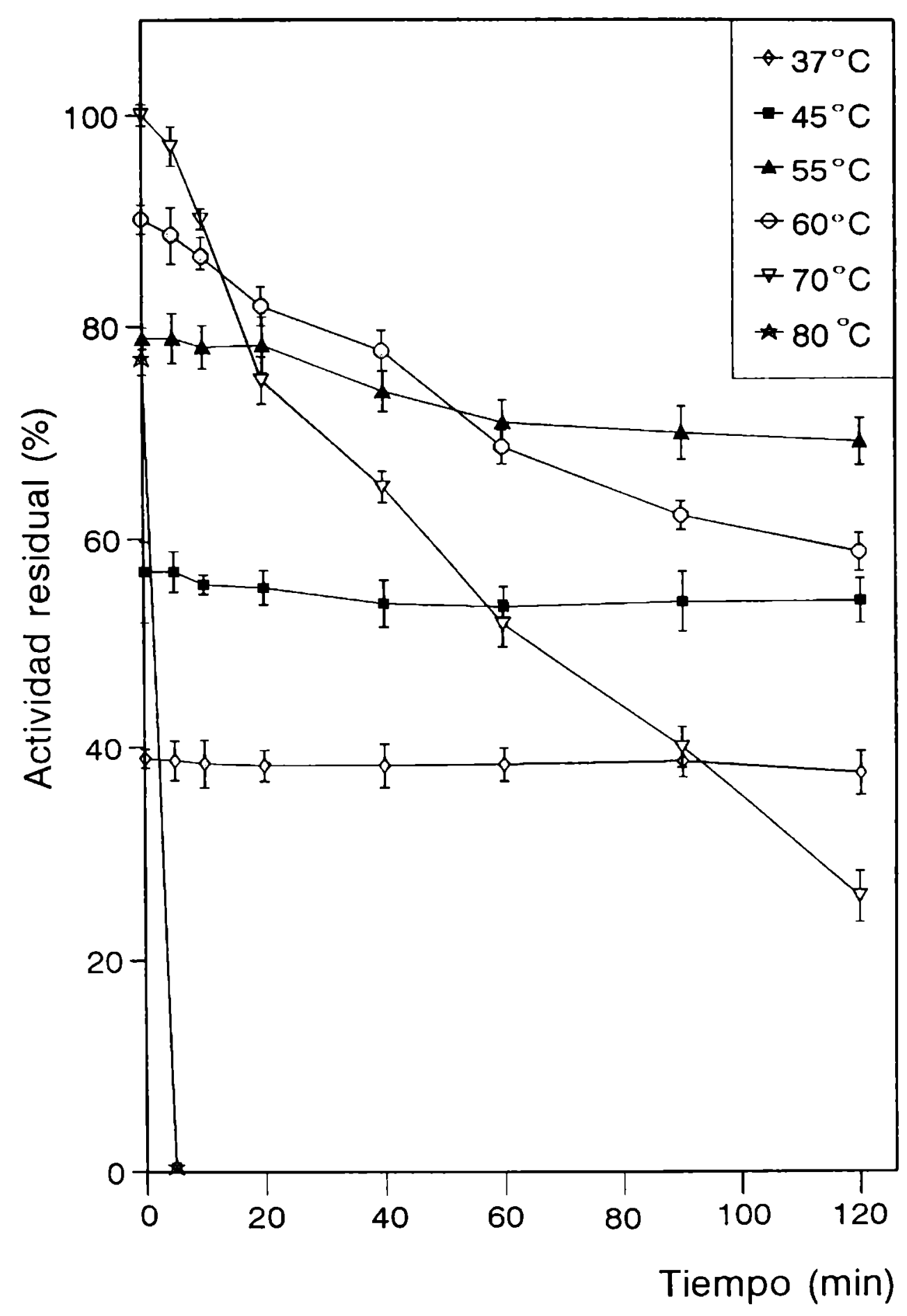

Figura 4.7. Efecto de diferentes tratamientos térmicos sobre la actividad de la preparación cruda. Finalizado cada período de incubación se midió la actividad caseinolítica residual a cada una de las temperaturas ensayadas a $\mathrm{pH}$ 8,0 durante dos minutos. Los datos resultan de promediar dos ensayos independientes $(n=5)$. Las barras representan la desviación estándar de los promedios. 
incubación. A $70^{\circ} \mathrm{C}$ la inactivación parcial de la enzima se traduce en una brusca disminución de la actividad residual (25\% a los 20 minutos y $75 \%$ a las 2 horas de incubación). La inactivación total de pomiferina se logra manteniéndola a $80^{\circ} \mathrm{C}$ durante 5 minutos.

\subsubsection{Efecto de activadores e inhibidores}

Este ensayo fue planteado con el fin de conocer el grupo mecanístico al que pertenece pomiferina. La tabla 4.2. muestra que la adición de EDTA (inhibidor de metaloproteinasas), cisteína (activador de proteasas cisteínicas), cloruro de calcio (activador de calpaínas y de algunas proteinasas serínicas), cloruro mercúrico e iodoacetato (inhibidores de proteasas cisteínicas) no modifican la actividad caseinolítica de las preparaciones crudas, pero en cambio el PMSF produce una inhibición que no es revertida por el agregado de cisteína. Estos resultados permiten concluir que las proteasas presentes en el látex de Maclura pomifera pertenecen al grupo de proteinasas serínicas que no requieren calcio como activador o estabilizador, confirmando la presunción de Tauber (1949) de que pomiferina no era una proteasa cisteínica.

\begin{tabular}{lrr} 
Agente químico & Concentración & $\begin{array}{c}\text { Actividad } \\
\text { relativa }\end{array}$ \\
\hline Ninguno & $10 \mathrm{mM}$ & $100 \pm 4$ \\
Aprotinina & $30 \mathrm{mM}$ & $97 \pm 3$ \\
Cisteílta & $5 \mathrm{mM}$ & $99 \pm 3$ \\
& $10 \mathrm{mM}$ & $99 \pm 4$ \\
Cloruro de calcio & $0,1 \mathrm{mM}$ & $99 \pm 3$ \\
& $1 \mathrm{mM}$ & $97 \pm 3$ \\
Cloruro mercúrico & $0,1 \mathrm{mM}$ & $100 \pm 2$ \\
& $1 \mathrm{mM}$ & $98 \pm 3$ \\
EDTA & $1 \mathrm{mM}$ & $100 \pm 2$ \\
& $5 \mathrm{mM}$ & $102 \pm 3$ \\
Ioduacetato de sodio & $0,1 \mathrm{mM}$ & $100 \pm 1$ \\
& $1 \mathrm{mM}$ & $97 \pm 3$ \\
PMSF & $1 \mathrm{mM}$ & $3 \pm 2$ \\
& $10 \mathrm{mM}$ & $4 \pm 2$ \\
PMSF (+Cys $12 \mathrm{mM})$ & $1 \mathrm{mM}$ & $4 \pm 1$
\end{tabular}

Tabla 4.2. Efecto de distintos activadores e inlhibidores de proteasas. Los datos resultan de promediar dos ensayos independientes $(n=5)$. Se indica la desviación estándar de los promedios. 


\subsubsection{Expresión de la actividad proteolítica de las preparaciones crudas frente a distintos sustratos}

Teniendo en cuenta la posible aplicación de las proteasas en procesos industriales y atendiendo a que en esos casos se recurre preferentemente al empleo de preparaciones poco purificadas, se consideró de utilidad aportar información de la actividad sobre distintos sustratos de las preparaciones crudas de las proteasas en estudio, a efectos de que pueda compararse su acción frente a preparaciones comerciales.

\begin{tabular}{lrl} 
Sustrato & \multicolumn{2}{l}{ Actividad } \\
\hline & & \\
Caseína & 2,9 & $\mathrm{U}_{\mathrm{cas}} / \mathrm{ml}$ \\
Azocaseína & 5,8 & $\mathrm{U}_{\mathrm{azocas}} / \mathrm{ml}$ \\
Azocolágeno & 10,5 & $\mathrm{U}_{\text {azocoll }} / \mathrm{ml}$ \\
Hemoglobina & 12,5 & U. Anson $/ \mathrm{ml}$
\end{tabular}

Pese a su buen valor nutricional y a su abundante disponibilidad, las proteínas presentes en concentrados de soja tienen deficitarias propiedades funcionales, lo que ha limitado su empleo con fines alimentarios; para mejorar estas últimas las preparaciones de soja han sido sometidas a proteólisis limitada con proteasas de diverso origen (Kim et al., 1990). En conocimiento de ello se decidió ensayar el comportamiento de pomiferina frente a las proteínas contenidas en concentrados de soja obtenidos en nuestro laboratorio, para lo cual se llevó a cabo un experimento en el que se determinó el grado de hidrólisis alcanzado y se analizaron los productos generados a lo largo del tiempo, en comparación con la proteólisis obtenida con alcalasa en la misma relación enzima/sustrato.

En la fig. 4.8. se representa el grado de hidrólisis logrado al hacer actuar pomiferina a tres valores de $\mathrm{pH}(8,9$ y 10$)$ dentro del rango de mayor actividad. A pH 8 los valores son significativamente menores, mientras que las curvas obtenidas a pH 9 y 10 son prácticamente coincidentes y el grado de hidrólisis obtenido a las tres horas corresponde a un $73 \%$ del producido por alcalasa en condiciones de pH óptimo.

Los productos de hidrólisis generados a lo largo del tiempo se analizaron por electroforesis en gradiente de poliacrilamida (6,5-20\%), cuyos resultados se consignan en 


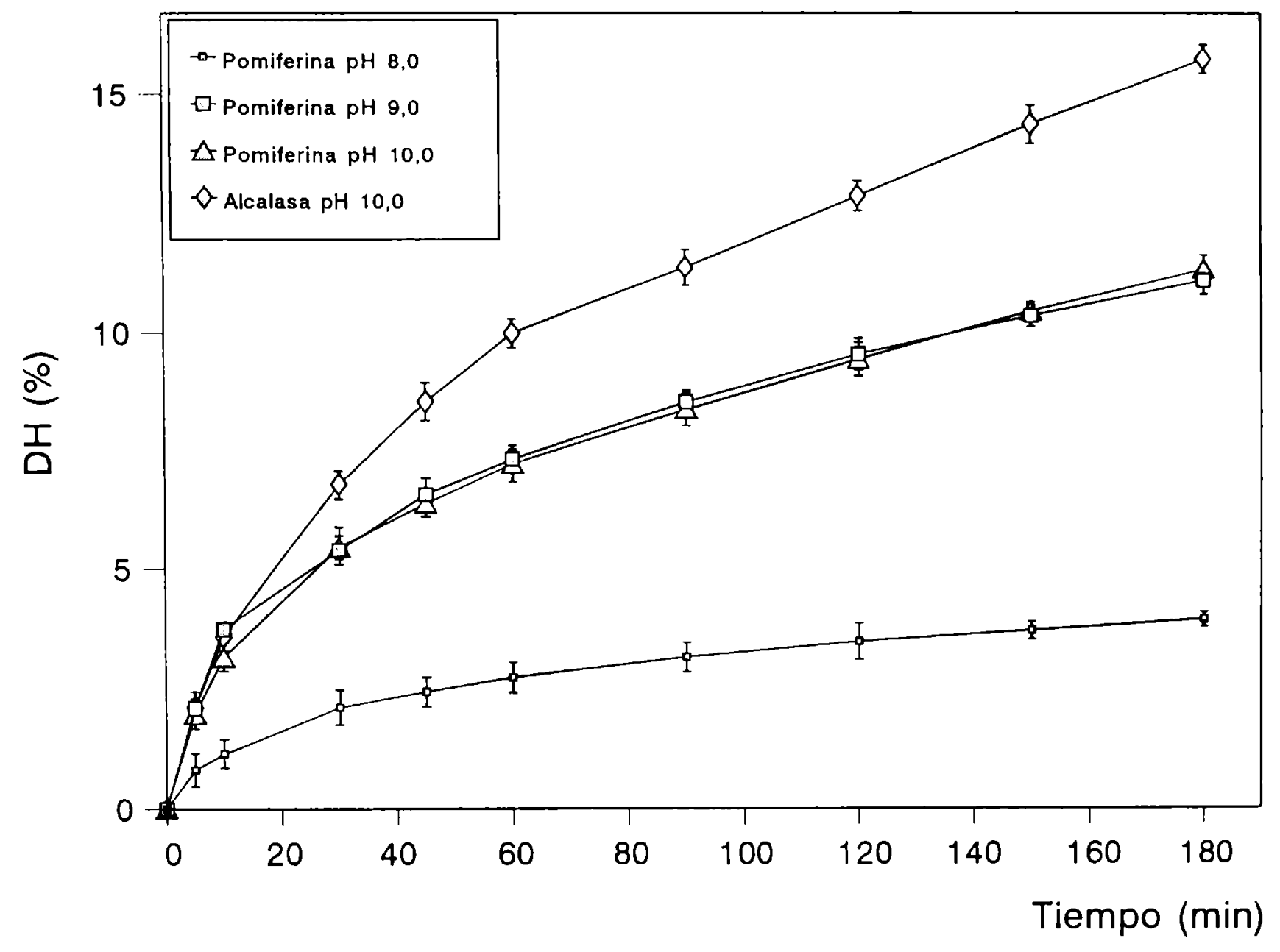

Figura 4.8. Grado de hidrólisis de concentrados de soja sometidos a la acción de pomiferina a diferentes valores de $\mathrm{pH}$ y de alcalasa a su $\mathrm{pH}$ óptino. 
la fig. 4.9. Ya a los dos minutos de hidrólisis la fitoproteasa ensayada produce una degradación parcial de los principales polipéptidos $\left(\alpha^{\prime}, \alpha, B, \mathrm{~A}\right.$ y B). En el mismo lapso alcalasa muestra un comportamiento que concuerda con el observado para las proteínas de aislados de soja (Kim et al., 1990), provocando la hidrólisis prácticamente completa de todas las fracciones mencionadas y generando un polipéptido de $c a .24 \mathrm{kD}$, que también es producido por la acción de pomiferina, aunque en menor proporción.

Al cabo de una hora de hidrólisis pomiferina degrada totalmente la fracción $\alpha^{\prime}$, quedando una muy baja proporción de las restantes fracciones. Como consecuencia del tratamiento enzimático más prolongado, tanto pomiferina como alcalasa producen un incremento de la fracción de ca. $24 \mathrm{kD}$ antes mencionada y en el caso de alcalasa se hace muy notoria una fracción de ca. $18 \mathrm{kD}$, apenas insinuada al comienzo de la hidrólisis.

\subsubsection{Ensayo de la actividad esterolítica con sustratos sintéticos}

A fin de evaluar el comportamiento de las preparaciones crudas frente a sustratos que contienen una unión éster escindible se determinaron las velocidades de hidrólisis enzimática utilizando los $N$-carbobenzoxi-p-nitrofenilésteres de los siguientes aminoácidos: L-alanina, L-asparagina, L-fenilalanina, glicina, L-leucina, L-lisina, Ltirosina, L-triptofano y L-valina, así como el $N$-carbobenzoxi- $\beta$-bencil-L-ácido aspártico$p$-nitrofeniléster y el $N$-carbobenzoxi- $S$-bencil-L-cisteína- $p$-nitrofeniléster. Dado que estos sustratos se hidrolizan espontáneamente en las condiciones de ensayo, se realizaron experiencias paralelas sin el agregado de enzima (hidrólisis no enzimática), que fueron descontados de los valores obtenidos en presencia de la enzima.

La curva de calibración para el 4-nitrofenolato fue realizada a $30^{\circ} \mathrm{C}$ y $405 \mathrm{~nm}$, mostrando una relación lineal entre la absorbancia y la concentración en el rango de interés para este trabajo, con un coeficiente de extinción molar del 4-nitrofenolato de $15,13 \times 10^{3} \mathrm{M}^{-1} \cdot \mathrm{cm}^{-1}$. En función de este dato se calcularon las $U_{\mathrm{cbz}}$ para cada uno de los sustratos empleados.

Los resultados de cada hidrólisis están informados en la tabla 4.3. La máxima actividad se obtiene cuando la enzima actúa sobre el derivado de alanina, seguido por el 


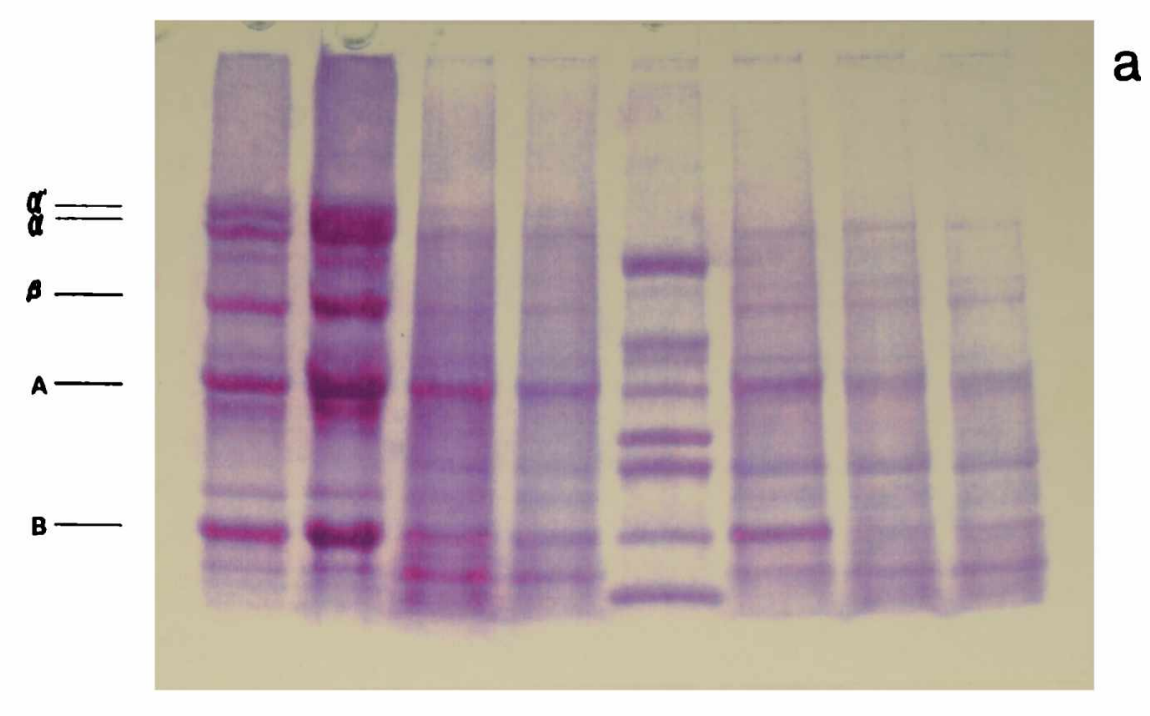

\section{$\begin{array}{llllllll}1 & 2 & 3 & 4 & 5 & 6 & 7 & 8\end{array}$}

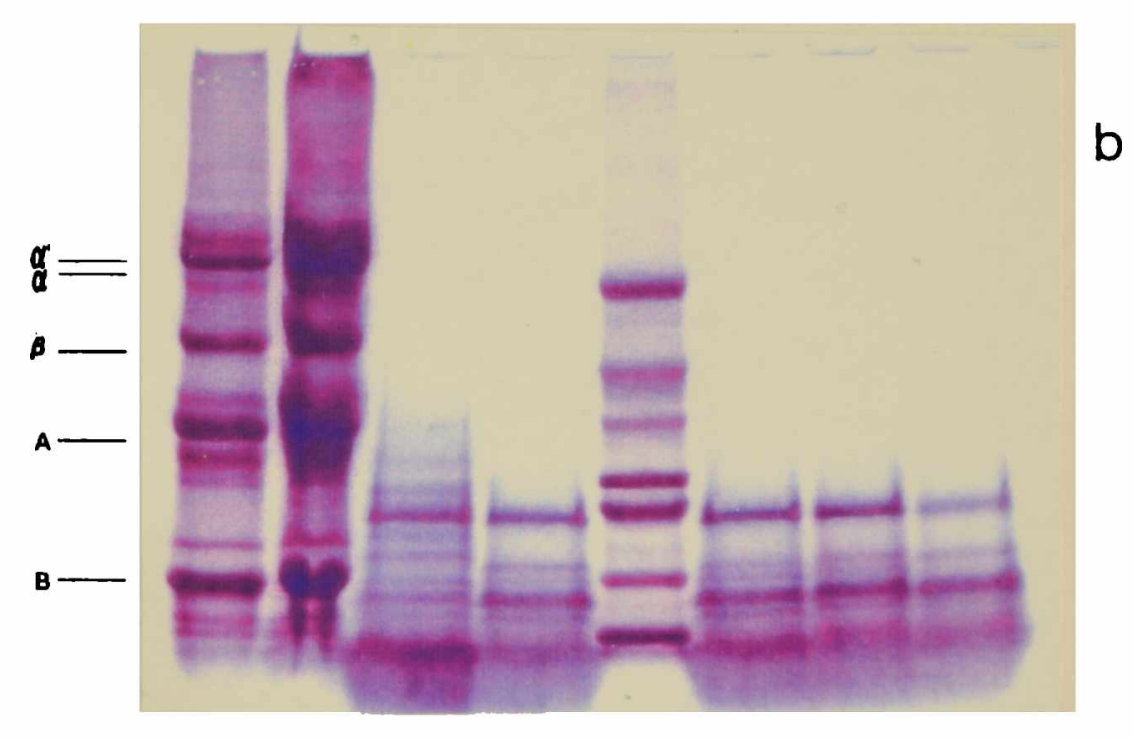

$\begin{array}{llllllll}1 & 2 & 3 & 4 & 5 & 6 & 7 & 8\end{array}$

Figura 4.9. Electroforesis en gradiente de poliacrilanida (6,5-20\%) en presencia de SDS de concentrados de soja sometidos a la acción de poniferina (a) y alcalasa (b). Carriles: 1) tiempo cero de hidrólisis, dilurdo; 2) tiempo cero de hidrólisis; 3) 2 min de hidrólisis; 4) 5 min de hidrólisis; 5) marcadores de bajo PM: albúmina bovina (66 kD), albúnina de huevo $(45 \mathrm{kD})$, gliceraldehido 3-P deshidrogenasa $(36 \mathrm{kD})$, anhidrasa carbónica $(29 \mathrm{kD})$, tripsinógeno $(24 \mathrm{kD})$, inhibidor de tripsina de soja $(20,1 \mathrm{kD})$ y $\alpha$-lactalbúmina bovina $(14,2 \mathrm{kD})$; 6) 30 min de hidrólisis; 7) 60 min de hidrólisis y 8) 90 min de hidrólisis. 
de glicina y el de leucina (las respectivas curvas de progreso de reacción se muestran en las figuras 4.10. a 4.12.). Si bien no se determinaron los parámetros $\mathrm{Km}$ y Vmáx para cada sustrato dado el elevado valor de los blancos, los datos obtenidos permiten inferir una preferencia de la enzima por uniones peptídicas en las que el aminoácido que aporta el grupo carboxilo sea de naturaleza no polar y/o de pequeño tamaño.

\begin{tabular}{lrcc} 
Aminoácido & $\begin{array}{c}\text { Actividad } \\
\mathrm{U}_{\mathrm{cbz}}\end{array}$ & $\begin{array}{c}\text { Actividad específica } \\
\mathrm{U}_{\mathrm{cbz}} / \mathbf{m g}\end{array}$ & $\begin{array}{c}\text { \% Actividad } \\
\text { relativa }\end{array}$ \\
\hline & & & \\
Ala & $232,15 \pm 2,90$ & $2,79 \pm 0,035$ & 100 \\
Gly & $170,93 \pm 1,08$ & $2,05 \pm 0,013$ & 74 \\
Leu & $106,09 \pm 0,70$ & $1,27 \pm 0,009$ & 46 \\
Phe & $31,38 \pm 0,40$ & $0,38 \pm 0,005$ & 14 \\
Val & $29,17 \pm 0,43$ & $0,35 \pm 0,005$ & 13 \\
Trp & $4,64 \pm 0,25$ & $0,06 \pm 0,003$ & 2 \\
Cys & $2,79 \pm 0,21$ & $0,03 \pm 0,002$ & 1 \\
Tyr & $1,26 \pm 0,20$ & $0,02 \pm 0,002$ & 1 \\
Lys & no detectable & & \\
Asn & no detectable & & \\
Asp & no detectable & &
\end{tabular}

Tabla 4.3. Actividad esterolítica de la preparación cruda.

\subsection{Purificación}

\subsubsection{Fraccionamiento acetónico}

Las preparaciones crudas contienen pigmentos e hidratos de carbono solubles que es necesario eliminar para evitar la inactivación de las proteasas y para disminuir la viscosidad de las soluciones a cromatografiar, respectivamente. Para ello se realizó una precipitación acetónica fraccionada siguiendo el esquema indicado en 3.14., cuyos resultados se consignan en la fig. 4.13. El procedimiento permite, además, separar una reducida proporción de proteínas inactivas.

Con la adición de un volumen de acetona se consigue eliminar los pigmentos y la casi totalidad (95\%) de los glúcidos, reteniendo el $85 \%$ de las proteínas y el $88 \%$ de la actividad. El agregado de un segundo volumen de acetona produce un precipitado rico en 


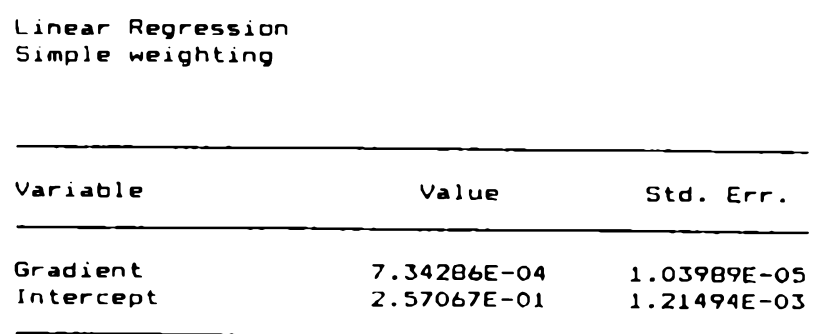

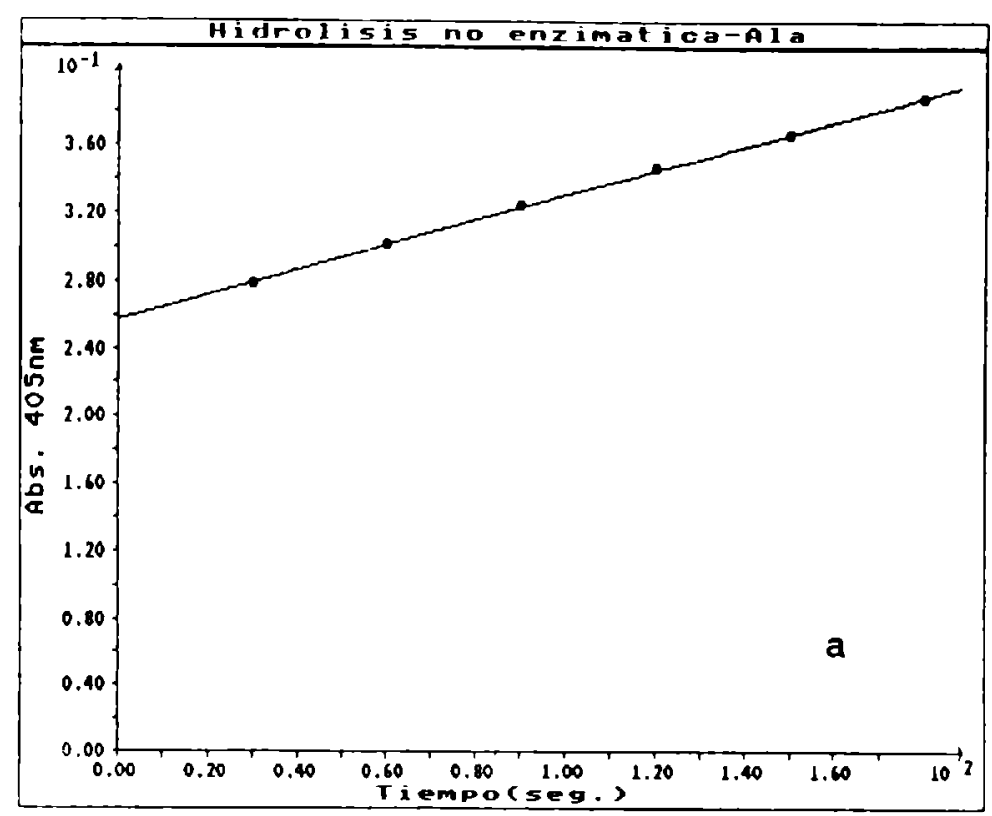

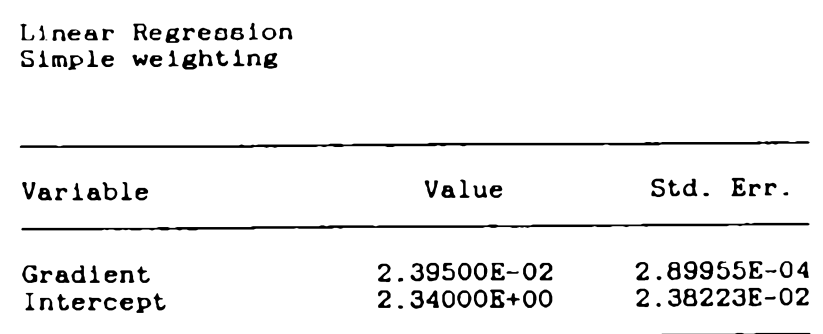

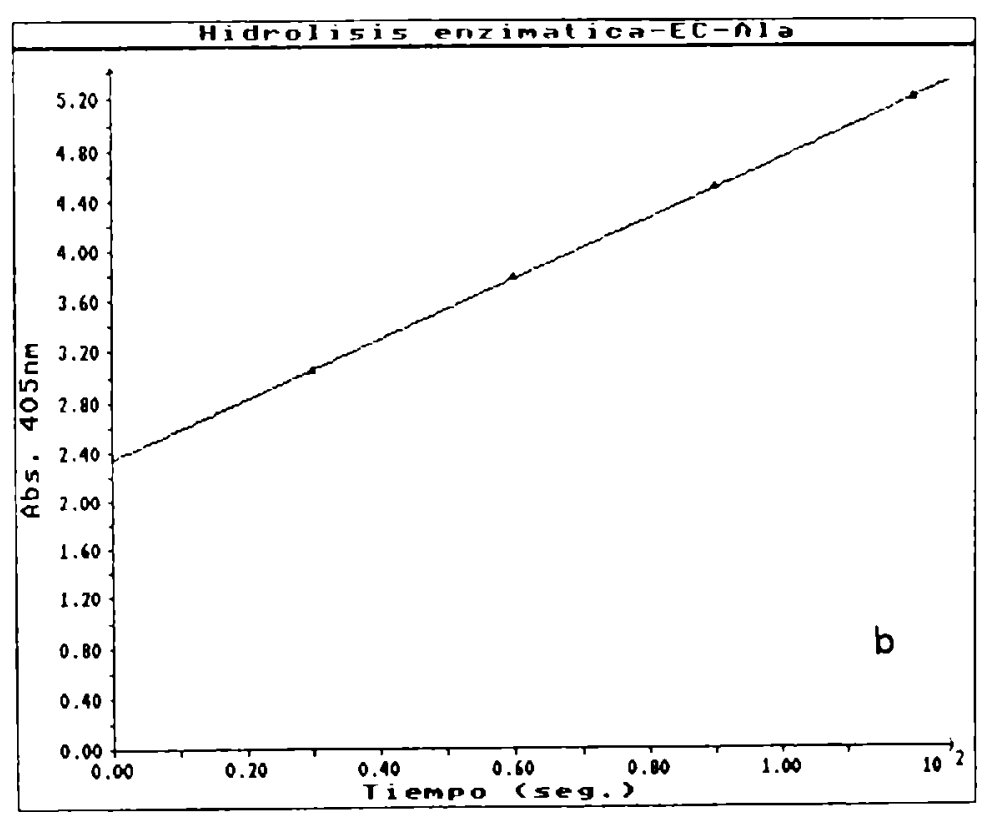

Figura 4.10. Curva de progreso de reacción sobre $N$-carbobenzoxi-L-alanina- $p$ nitrofeniléster. a: hidrólisis no enzinática; b: hidrólisis enzimática (preparación cruda). 
Linear Regression Simple weighting

\begin{tabular}{lcc}
\hline Variable & value & std. Err. \\
\hline $\begin{array}{l}\text { Gradient } \\
\text { Intercept }\end{array}$ & $9.16667 E-04$ & $3.33167 E-06$ \\
& $1.96700 E-01$ & $3.31497 E-04$
\end{tabular}

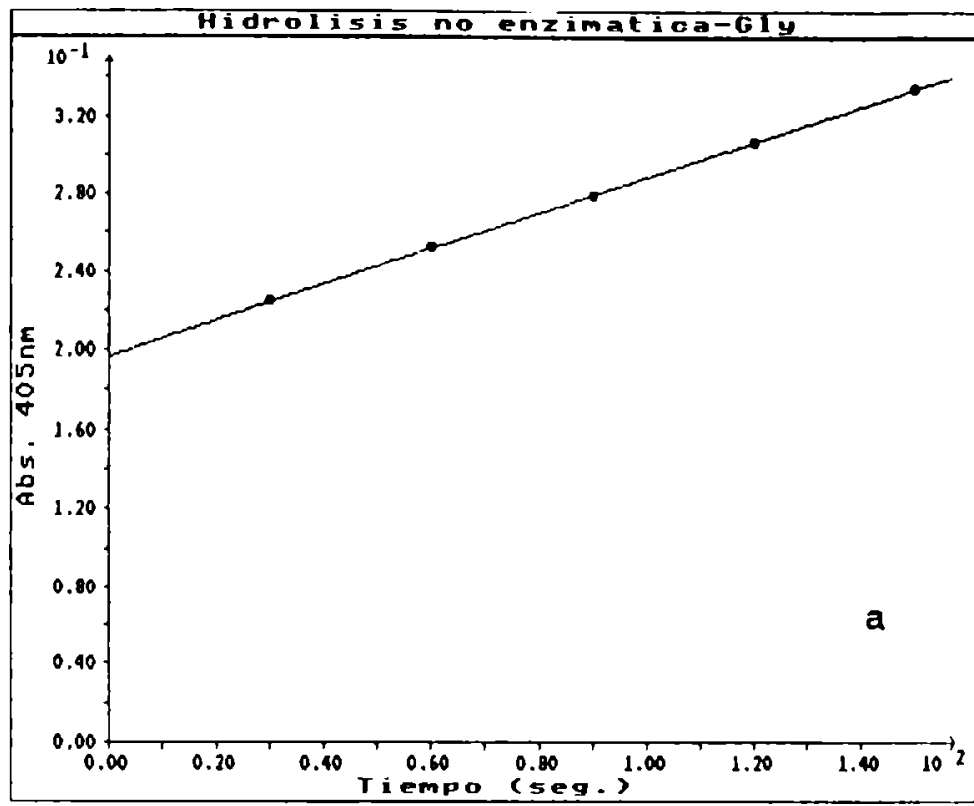

Linear Regression

Simple weighting

\begin{tabular}{lcc}
\hline Variable & Value & Std. Err. \\
\hline Gradient & $1.80952 \mathrm{E}-02$ & $1.08363 \mathrm{E}-04$ \\
Intercept & $6.88333 \mathrm{E}-01$ & $1.26604 \mathrm{E}-02$ \\
\hline
\end{tabular}

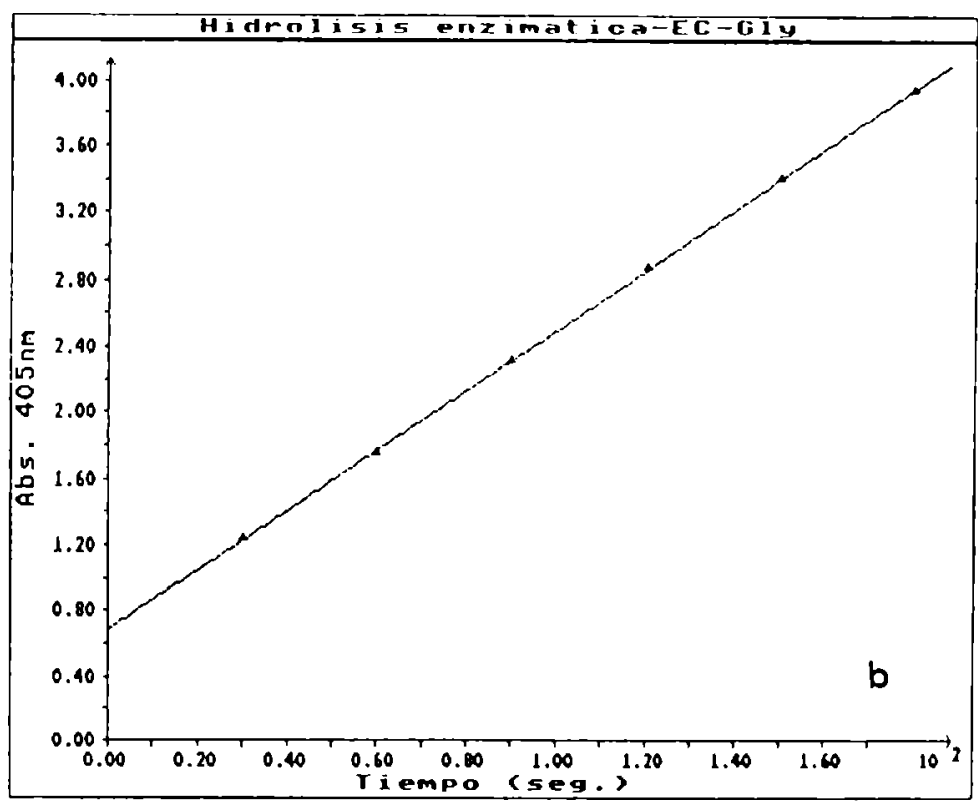

Figura 4.11. Curva de progreso de reacción sobre $N$-carbobenzoxi-glicina- $p$ nitrofenilester. a: hidrólisis no enzimática; b: hidrólisis enzimática (preparación cruda). 


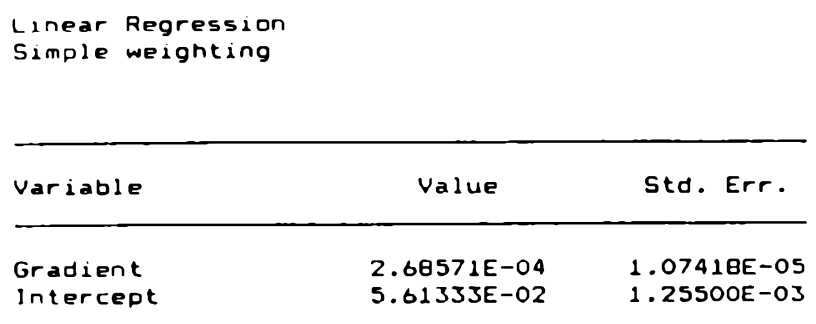

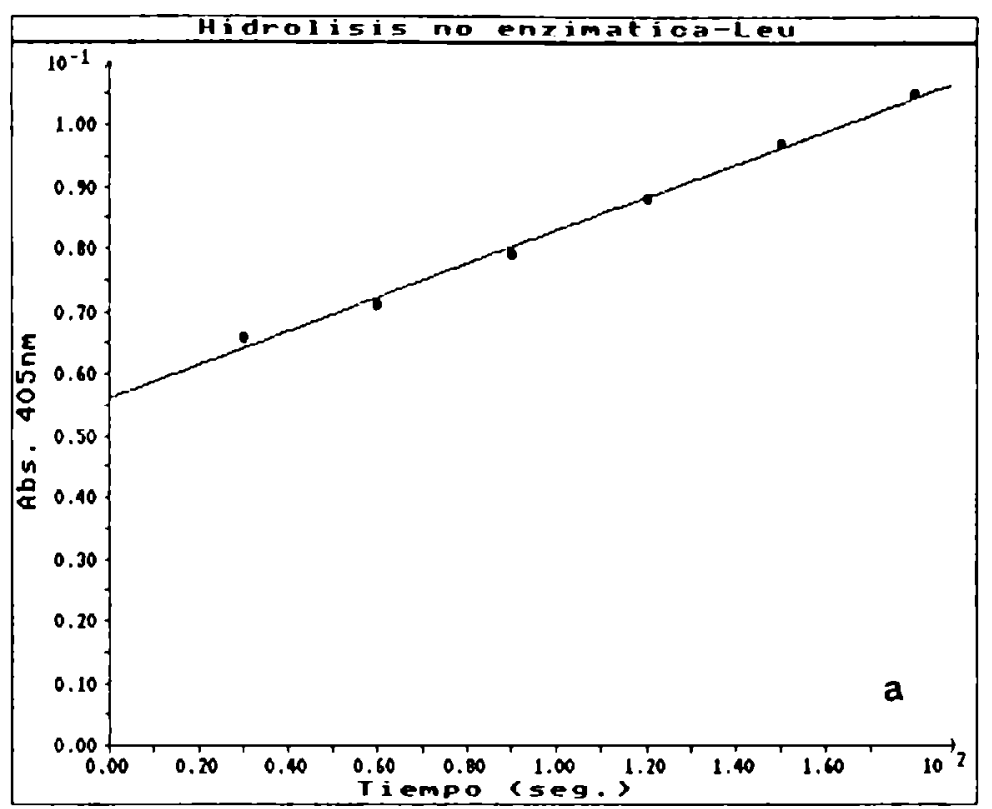

Linear Regression

Simple welghting

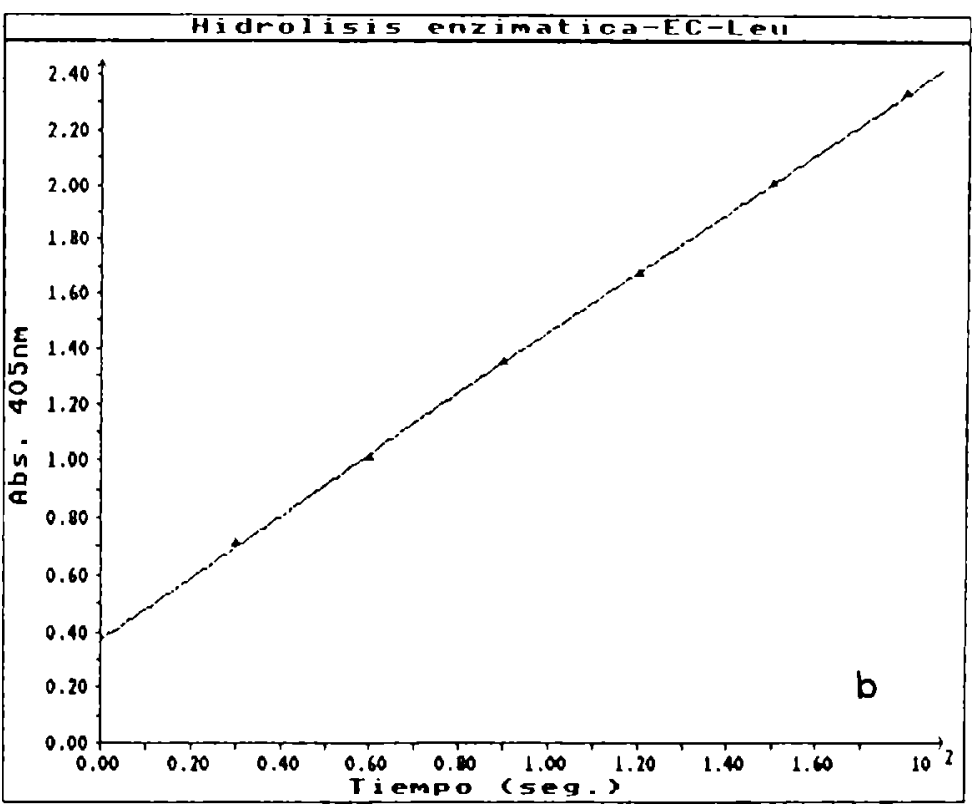

Figura 4.12. Curva de progreso de reacción sobre $N$-carbobenzoxi-L-leucina-pnitrofeniléster. a: hidrólisis no enzimática; b: hidrólisis enzimática (preparación cruda). 


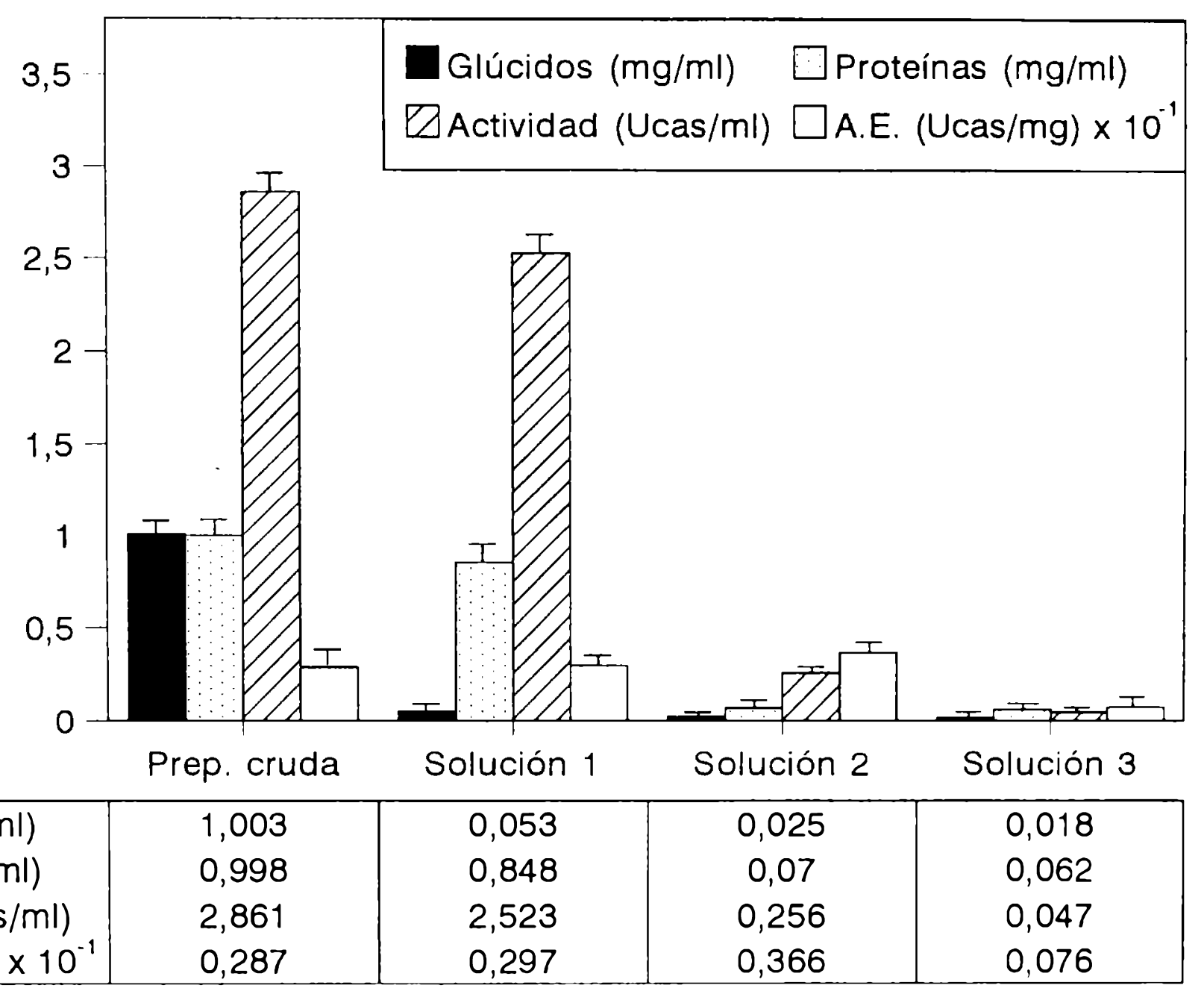

Figura 4.13. Precipitación acetónica fraccionada de las preparaciones crudas. Los resultados corresponden a la aplicación del esquema de purificación indicado en 3.14. 
proteína activa, a pesar de su bajo contenido en proteínas totales (7\%); un tercer volumen de acetona permite recuperar una cantidad equivalente de proteína, pero con actividad proteolítica despreciable. En base a estos datos se resolvió precipitar las preparaciones crudas directamente con dos volúmenes de acetona, con lo que se obtiene un precipitado blanquecino que contiene solamente el $8 \%$ de los hidratos de carbono originales, conservando el $92 \%$ de las proteínas presentes en la preparación cruda y reteniendo el $97 \%$ de la actividad inicial.

\subsubsection{Ensayos de autodigestión del precipitado acetónico}

Teniendo en cuenta que las proteasas incrementan su tendencia a autodigerirse a medida que la solución se enriquece en proteína activa, se determinó la actividad caseinolítica residual de muestras de pomiferina parcialmente purificada por precipitación acetónica mantenidas a temperatura ambiente $\left(20^{\circ} \mathrm{C}\right)$ durante 24 horas. En la fig. 4.14. se consignan los resultados de esta experiencia: al cabo de tres horas de reacción se advierte una disminución de la actividad caseinolítica residual de alrededor del 10\%, llegándose a una actividad residual del $75 \%$ después de 24 horas en las condiciones indicadas.

Con el propósito de correlacionar la pérdida de actividad caseinolítica con la modificación de la composición proteica de la muestra se realizó un análisis electroforético utilizando un gel en gradiente de poliacrilamida (8-20\%) en presencia de SDS (fig. 4.15.).

A tiempo cero se observan tres fracciones $\left(\mathrm{P}_{1}, \mathrm{P}_{2}\right.$ y $\left.\mathrm{P}_{3}\right)$, cuyos pesos moleculares son del orden de los determinados para las proteasas purificadas. En la región correspondiente a pesos moleculares más bajos se destacan seis fracciones principales (A. $\mathrm{B}, \mathrm{C}, \mathrm{D}, \mathrm{E}$ y F) de pesos moleculares entre 29 y $16 \mathrm{kD}$. A las de tres horas de incubación se nota una disminución de $P_{1}$ y un aumento de $P_{3}$, al tiempo que se reducen sensiblemente las fracciones $E$ y $F$, apareciendo una nueva banda $(G)$ de peso molecular $14,5 \mathrm{kD}$. A las 24 horas los polipéptidos proteolíticamente activos prácticamente quedan reducidos a la fracción $P_{3}$, en tanto que aparecen nuevas bandas de pesos moleculares intermedios entre los de $\mathrm{P}_{3}$ y $\mathrm{A}$. El resto de las fracciones, $\mathrm{A}, \mathrm{B}$, y $\mathrm{C}$ no parecen sufrir 


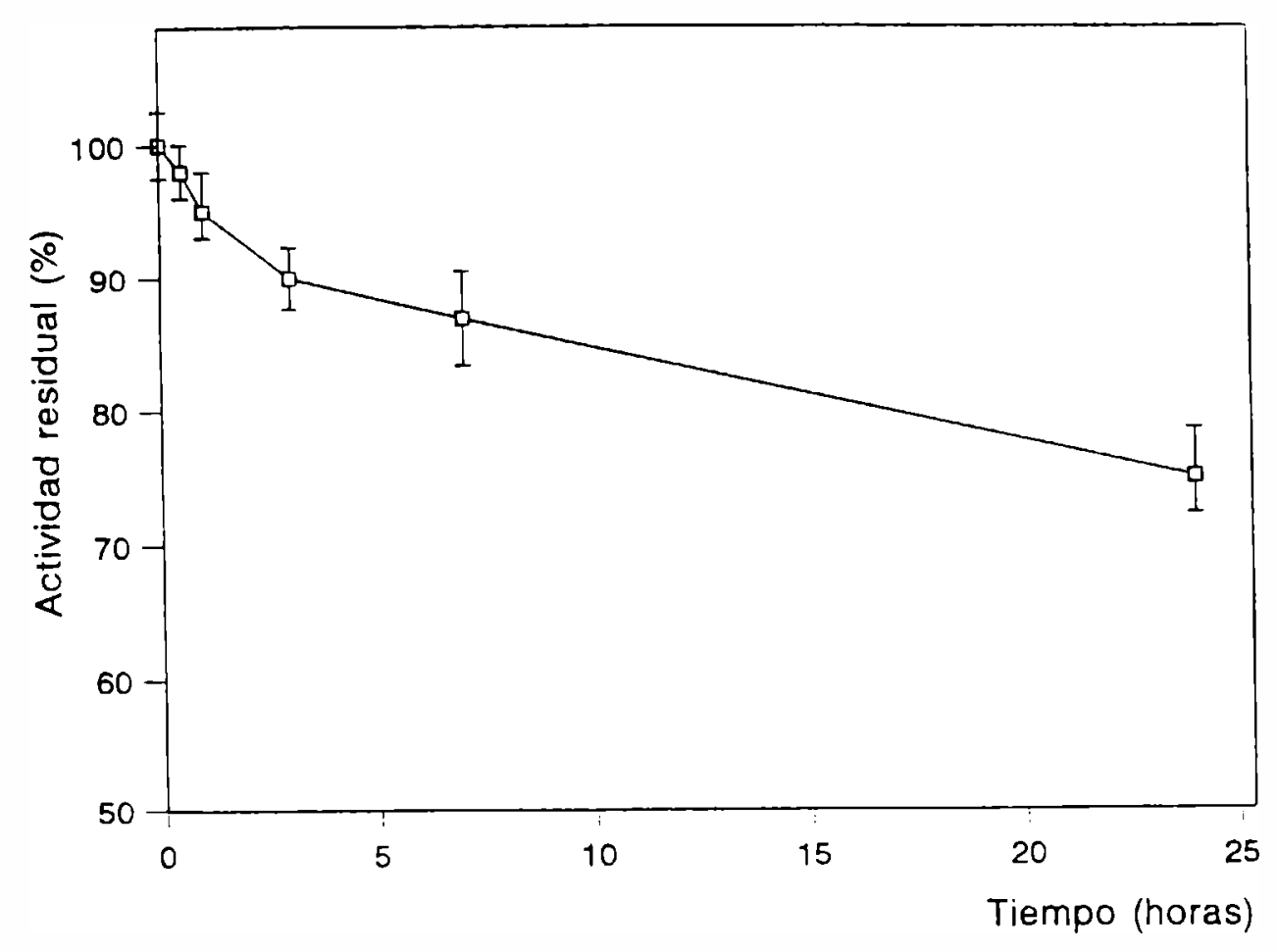

Figura 4.14. Efecto de la autodigestión de precipitados acetónicos sobre la actividad caseinolítica

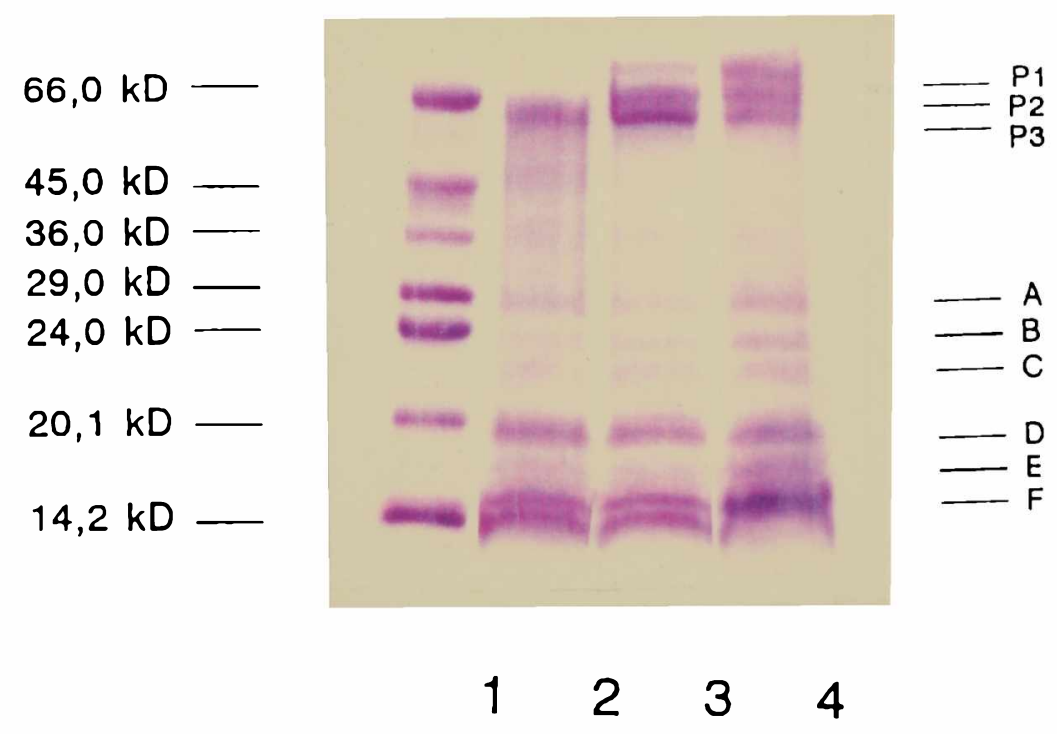

Figura 4.15. Electroforesis en gradiente de poliacrilamida (8-20\%) en presencia de SDS de precipitados acetónicos sometidos a autodigestión. Carril 1: marcadores de bajo PM: albúmina bovina $(66 \mathrm{kD})$, albúmina de huevo $(45 \mathrm{kD})$, gliceraldehido 3-P deshidrogenasa $(36 \mathrm{kD})$, anhidrasa carbónica $(29 \mathrm{kD})$, tripsinógeno $(24 \mathrm{kD})$, inhibidor de tripsina de soja $(20,1 \mathrm{kD})$ y $\alpha$ lactalbúmina bovina $(14,2 \mathrm{kD})$; carril 2: precipitado acetónico luego de 24 horas de incubación a $20^{\circ} \mathrm{C}$; carril 3: precipitado acetónico luego de tres horas de incubación a $20^{\circ} \mathrm{C}$; carril 4 : precipitado acetónico sin incubar 
modificaciones con respecto al resultado obtenido a las tres horas, mientras que $\mathrm{F}$ y $\mathrm{G}$ incrementan ligeramente su concentración.

Dadas las condiciones en las que fue llevada a cabo la electroforesis, que impiden la recuperación de la actividad enzimática, no fue posible realizar el correspondiente zimograma para comprobar si las fracciones que aparecen como consecuencia de la autodigestión siguen siendo activas, como parecen indicar los elevados resultados de actividad residual que muestra la fig. 4.14.

\subsubsection{Cromatografía de intercambio aniónico}

El precipitado acetónico, desprovisto de la casi totalidad de los carbohidratos solubles presentes en las preparaciones crudas, fue purificado en una primera etapa por cromatografía de intercambio aniónico. Se utilizó para tal fin una columna rellena con DEAE-Sepharose Fast Flow equilibrada con buffer Tris- $\mathrm{HCl} 50 \mathrm{mM}$ de $\mathrm{pH} 8,0$.

En la fig. 4.16. se muestran los cromatogramas obtenidos al aplicar distintas condiciones de elución ( $\mathrm{NaCl}$ 0,0-1,0 M, 0,0-0,5 $\mathrm{M}$ y 0,0-0,25 $\mathrm{M}$ ), donde puede apreciarse que los mejores resultados se obtuvieron aplicando un gradiente de $\mathrm{NaCl} 0,0$ 0,25 M disuelto en el buffer de partida. Con el lavado inicial eluyó una importante fracción proteica no homogénea que resultó ser activa. La aplicación del gradiente elegido permitió separar dos fracciones proteolíticamente activas (I y II), de pI inferior a 8, que eluyen de la columna cuando la concentración de cloruro de sodio alcanza valores de 0,08 $\mathrm{M}$ y $0,18 \mathrm{M}$, respectivamente.

\subsubsection{Cromatografía de intercambio catiónico}

La aplicación directa de la fracción activa no retenida en la cromatografía de intercambio aniónico a una columna de intercambio catiónico (CM-Sepharose Fast Flow equilibrada con buffer Tris- $\mathrm{HCl} 50 \mathrm{mM}$ de $\mathrm{pH}$ 8,0) no dio resultado, dado que la mayor parte de aquélla eluyó en la etapa inicial de lavado, sin que se lograra una buena 

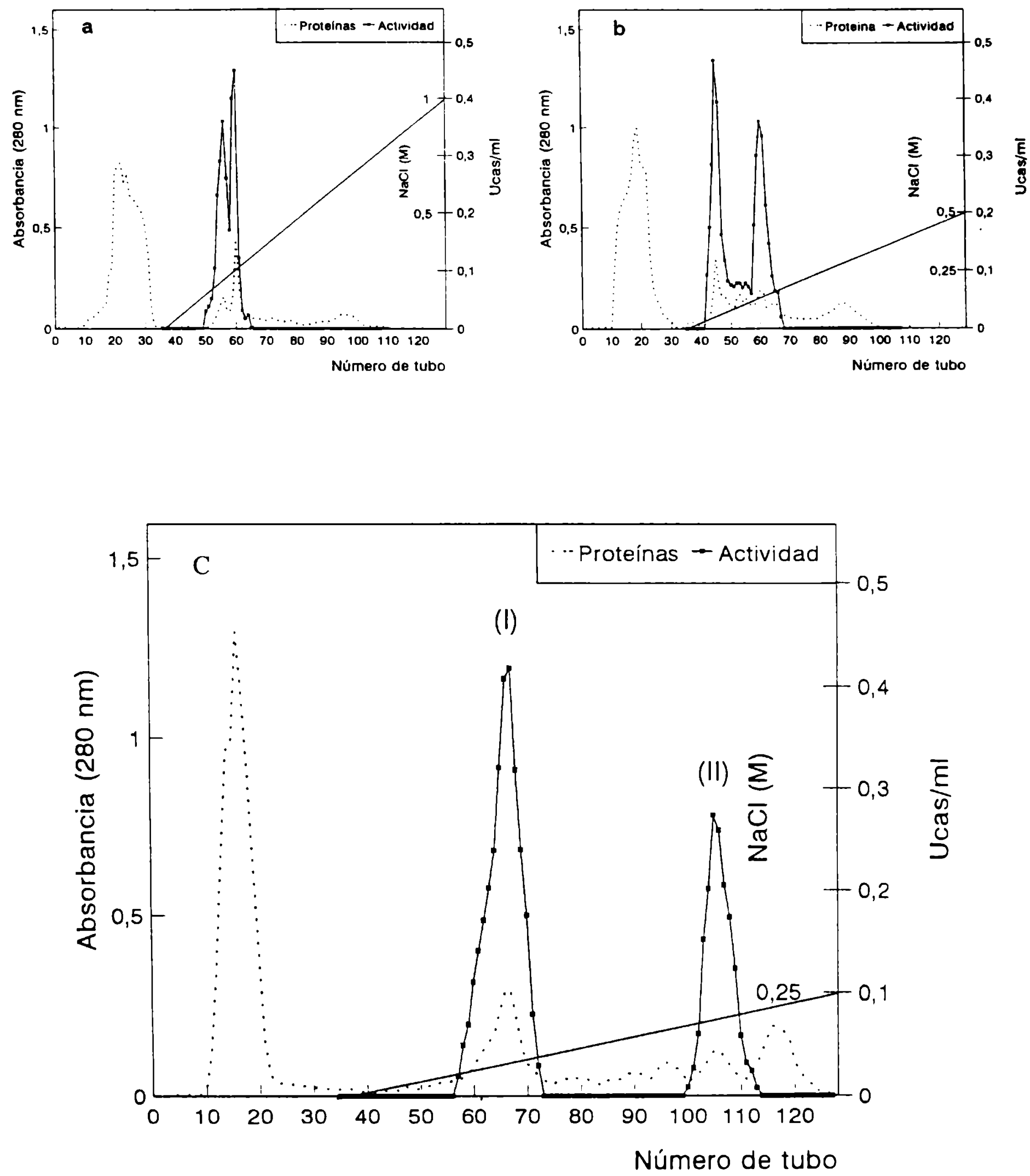

Figura 4.16. Cromatografías sobre DEAE-Sepharose Fast Flow del precipitado acetónico redisuelto: a) gradiente de cloruro de sodio $0,0-1,0 \mathrm{M}$; b) gradiente de cloruro de sodio $0,0-0,5 \mathrm{M}$; c) gradiente de cloruro de sodio 0,0 - 0,25 M. Buffer de partida: Tris- $\mathrm{HCl}$ $50 \mathrm{mM}$ (pH 8,0); volumen de sienbra: $20 \mathrm{ml}$; velocidad de flujo: $8 \mathrm{~cm}^{3} \cdot \mathrm{h}^{-1}$; se recogieron fracciones de 1,8 $\mathrm{cm}^{3}$. Fracción I: tubos 64-70; Fracción II: tubos 103-109. 
resolución (fig. 4.17.a). En consecuencia resultó necesario modificar las características del buffer para que las proteínas fueran totalmente retenidas por el intercambiador catiónico, lo que se logró al reducir la fuerza iónica y disminuir ligeramente el pH (buffer fosfatos $10 \mathrm{mM}$ de $\mathrm{pH}$ 7,5). Por otra parte, el cambio de la especie bufferante permitió evitar los disturbios locales de $\mathrm{pH}$ que se producen cuando la misma posee igual carga que el intercambiador.

Una vez equilibrada la muestra con el nuevo buffer a través del proceso de diafiltración, como se indicó en 3.17., la misma fue sembrada en la columna conteniendo el intercambiador catiónico, ensayándose distintos gradientes de elución (fig. 4.17. b, c). La mejor resolución se obtuvo al aplicar un gradiente de $\mathrm{NaCl} 0,0-0,45 \mathrm{M}$ disuelto en el buffer de partida, que permitió eluir una fracción proteolítica principal (III) cuando el mismo alcanzó una concentración $0,15 \mathrm{M}$ y una última fracción activa (IV) cuando se llegó a una concentración 0,23 M.

\subsubsection{Seguimiento de la purificación}

Los resultados del esquema de purificación aplicado se muestran en la Tabla 4.4.

\begin{tabular}{lccccc}
\hline Etapa & $\begin{array}{c}\text { Actividad } \\
\text { (Ucas) }\end{array}$ & $\begin{array}{c}\text { Protefnas } \\
(\mathrm{n} g)\end{array}$ & $\begin{array}{c}\text { Act.especffica } \\
\left(\text { Ucas.mg }^{-1}\right)\end{array}$ & $\begin{array}{c}\text { Purificacion } \\
\text { (veces) }\end{array}$ & $\begin{array}{c}\text { Rendimiento } \\
(\%)\end{array}$ \\
\hline P.C. & 56,70 & 19,80 & 2,86 & 1,0 & 100,0 \\
P.A. & 55,03 & 18,22 & 3,02 & 1,1 & 97,0 \\
I & 2,60 & 0,48 & 5,43 & 1,9 & 4,6 \\
II & 2,73 & 0,43 & 6,36 & 2,2 & 4,8 \\
III & 10,10 & 1,07 & 9,44 & 3,3 & 17,8 \\
IV & 7,50 & 0,71 & 10,58 & 3,7 & 13,2
\end{tabular}

Tabla 4.4. Purificación de las proteasas presentes en el látex de frutos de Maclura pomifera. P.C.: preparación cruda; P.A.: precipitado acetónico redisuelto; I y II: fracciones separadas por cromatografia de intercambio aniónico; III y IV: fracciones separadas por cromatografia de intercambio cationico. 

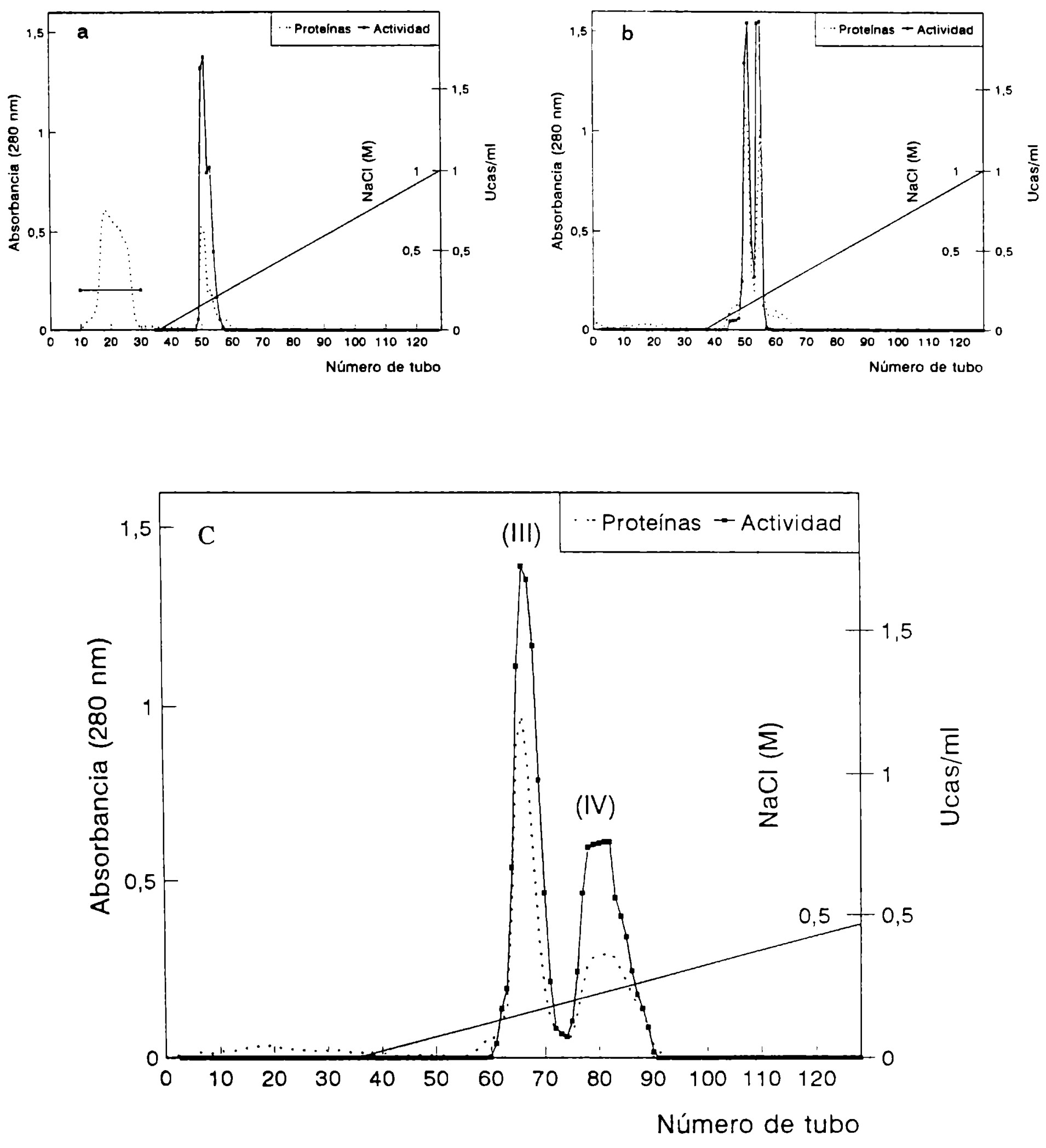

Figura 4.17. Cromatografias sobre CM-Sepharose Fast Flow de la fracción no retenida en DEAE-Sepharose Fast Flow (tubos 10 al 21): a) buffer de partida: Tris- $\mathrm{HCl} 50 \mathrm{mM}$ (pH 8,0), gradiente de cloruro de sodio $0,0-1,0 \mathrm{M}$; b) buffer de partida: fosfato de sodio $10 \mathrm{mM}$ (pH 7,5), gradiente de cloruro de sodio $0,0-1,0 \mathrm{M}$; c) buffer de partida: fosfato

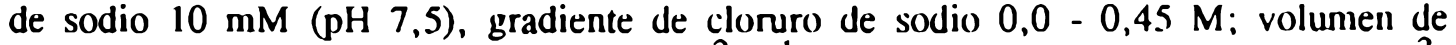
siembra: $20 \mathrm{ml}$; velocidad de flujo: $8 \mathrm{~cm}^{3} . \mathrm{h}^{-1}$; se recogieron fracciones de $1,8 \mathrm{~cm}^{3}$. Fracción IIl: tubos 64-71; Fracción IV: tubos 103-109. 
La precipitación acetónica fraccionada -primera etapa de la purificación- elimina componentes no proteicos (esencialmente carbohidratos y pigmentos) y en menor medida proteínas $(8 \%)$, en su mayoría inactivas, ya que el rendimiento de esta etapa implica tan sólo una disminución del $3 \%$ de la actividad inicial.

La aplicación de las dos etapas cromatográficas subsiguientes permite obtener cuatro fracciones activas que, en conjunto, retienen el $42,6 \%$ de la actividad contenida en el precipitado acetónico. Aunque el porcentaje de la actividad recuperada podría hacer suponer una baja eficiencia de estas etapas de purificación, debe tenerse en cuenta que los valores consignados para cada fracción resultan de la reunión del material que corresponde solamente a la zona central de cada uno de los "picos" del respectivo cromatograma, con lo que se sacrifica buena parte de la proteína activa para evitar la contaminación con otras especies proteicas. En estas condiciones se ha logrado separar dos fracciones minoritarias (I y II) de bajo pI (a pH 8 quedan retenidas por el intercambiador aniónico) y dos fracciones principales (III y IV) que representan el $77 \%$ de la actividad recuperada y que poseen las mayores actividades específicas.

El bajo grado de purificación alcanzado (3,7 veces la fracción IV) obedece tanto a la naturaleza del material de partida (látex, en lugar de un extracto de tejidos vegetales, lo que implica que su contenido proteico está representado mayoritariamente por proteasas), como a la especie vegetal de la que se trata, seleccionada precisamente por su elevado contenido en enzimas proteolíticas.

\subsubsection{Pesos moleculares de las fracciones purificadas}

La electroforesis en gel de poliacrilamida en presencia de dodecilsulfato de sodio (fig. 4.18.) revela que los pesos moleculares de las cuatro fracciones proteolíticas purificadas son bastante cercanos entre sí (fracción I: 71,2 kD; fracción II: 62,7kD; fracción III: $69,7 \mathrm{kD}$; fracción IV: $69,9 \mathrm{kD}$ ) y del mismo orden que los encontrados en otras proteinasas serínicas (Curotto et al., 1989; Kaneda y Tominaga, 1975; Kaneda y Tominaga, 1977; Lynn y Clevette-Radford, 1988). 


\subsubsection{Puntos isoeléctricos de las fracciones purificadas}

Las fracciones purificadas fueron analizadas por isoelectroenfoque en gel de poliacrilamida, utilizando un gradiente de pI 3-10 (fig. 4.19.). En concordancia con la información provista por la cromatografía de intercambio iónico, las fracciones retenidas por el intercambiador aniónico poseen puntos isoeléctricos inferiores al $\mathrm{pH}$ del buffer de elución (fracción $\mathrm{I}: \mathrm{pI}=6,2$; fracción $\mathrm{II}: \mathrm{pI}=4,3$ ), en tanto que las fracciones no retenidas a pH 8 (luego resueltas por intercambio catiónico) presentan puntos isoeléctricos más elevados (fracción III: $\mathrm{pI}=8,9$; fracción IV: $\mathrm{pI}=9,4$ ).

La mayoría de las proteasas de látex poseen valores de puntos isoeléctricos superiores a 8 (Boller, 1986), aún cuando la presencia de proteasas con un variado rango de pI que provienen del mismo material no es un hecho aislado (Barragán et al., 1985; Tablero et al., 1991).

\subsection{Caracterización parcial de la fracción III}

Por tratarse de la fracción purificada de mayor rendimiento, la fracción III fue sometida a una serie de ensayos tendientes a correlacionar su comportamiento con el de la preparación cruda.

\subsubsection{Efecto de pH sobre la actividad proteolítica}

Se ensayó la actividad proteolítica en el intervalo de $\mathrm{pH} 6,2$ - 11,6, utilizando caseína como sustrato. Los resultados obtenidos se muestran en la fig. 4.20. El rango de mayor actividad proteolítica (actividad relativa superior al 90\%) está ubicado entre pH 9,0 y 10,6 , aún cuando la actividad es significativamente elevada ( $60 \%$ del valor máximo) entre $\mathrm{pH} 7,0$ y 11,2 y al menor valor ensayado $(\mathrm{pH} 6,2)$ aún retiene el $50 \%$ de actividad. Por encima de $\mathrm{pH}$ 10,4 se produce un brusco descenso de la actividad, que reduce la misma a un $40 \%$ a pH 11,5 . 


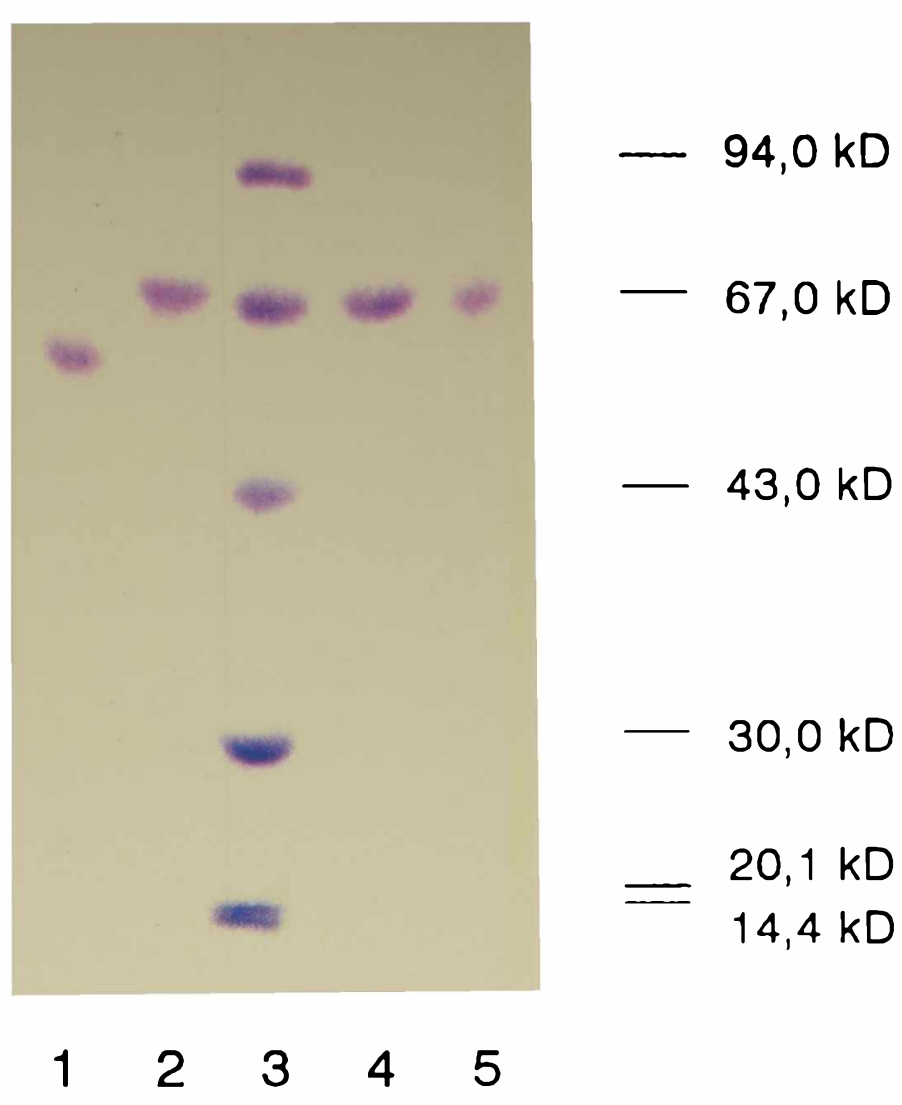

Figura 4.18. Electroforesis en gel de poliacrilamida (Laemnli, 1970) de las enzimas purificadas. Carril 1) fracción II; carril 2) fracción I; carril 3) patrones de bajo peso molecular: $\alpha$-lactalbúmina $(14,4 \mathrm{kD})$, inhibidor de tripsina $(20,1 \mathrm{kD})$, anhidrasa carbónica $(30 \mathrm{kD})$, ovalbúmina $(43 \mathrm{kD})$, albúmina $(67 \mathrm{kD})$ y fosforilasa b $(94 \mathrm{kD})$; carril 4) fracción III; carril 5) fracción IV.

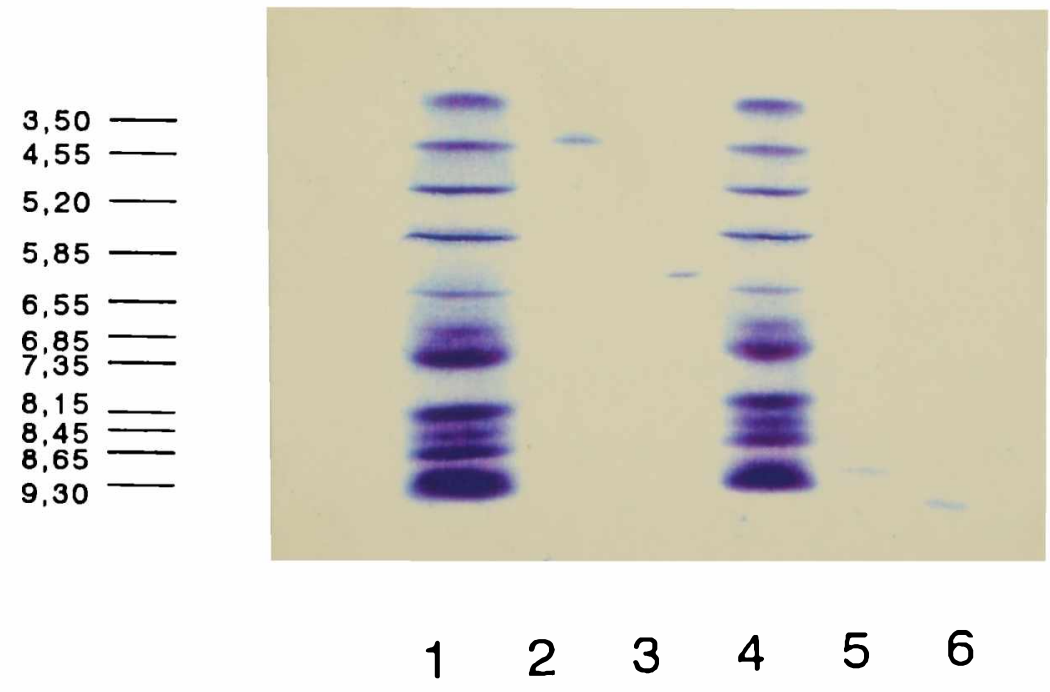

Figura 4.19. Isoelectroenfoque en gel de poliacrilanida de las enzimas purificadas. Carril 1) patrones de punto isoeléctrico: aniloglucosidasa ( $\mathrm{pl} 3,50$ ), inhibidor de tripsina ( $\mathrm{pl}$ 4,55), B-lactoglobulina A (pI 5,20), anhidrasa carbónica B, bovina (pI 5,85), anhidrasa carbónica B, humana (pI 6,55), mioglobina, banda ácida (pl 6,85), mioglobina, handa básica (pl 7,35), lentil lectina, ácida (pl 8,15), lentil lectina, media (pl 8,45) lentil lectina, básica (pI 8,65), tripsinógeno (pI 9,30); carril 2) fracción II; carril 3) fracción I: carril 4) patrones de punto isoelectrico; carril 5) fracción III; carril 6) fracción IV. 
A efectos comparativos se han incluido en la fig. 4.20 los datos correspondientes a la preparación cruda. Como puede apreciarse, ambos perfiles resultan prácticamente coincidentes.

\subsubsection{Estabilidad térmica}

La fig. 4.21. muestra las variaciones que sufre la actividad caseinolítica a lo largo del tiempo con respecto al valor inicial para cada una de las temperaturas ensayadas. Luego de mantener la enzima durante dos horas a $37^{\circ} \mathrm{C}$ o a $45^{\circ} \mathrm{C}$ la actividad disminuye sólo ligeramente. A $60^{\circ} \mathrm{C}$ la actividad residual se ve afectada notoriamente, disminuyendo en un $42 \%$ a la hora de incubación y en un $80 \%$ a las dos horas. A $70^{\circ} \mathrm{C}$ la inactivación parcial de la enzima se traduce en una muy marcada disminución de la actividad residual (32\% a los 20 minutos y $95 \%$ a las 2 horas de incubación). La inactivación total de la fracción III de pomiferina se logra manteniéndola a $80^{\circ} \mathrm{C}$ durante 5 minutos.

Comparando estos resultados con los obtenidos para la preparación cruda (fig. 4.7.) es de destacar la mayor sensibilidad al tratamiento térmico que muestra la fracción purificada, lo que era de esperar como consecuencia de la eliminación de carbohidratos solubles que se produce durante el proceso de purificación de la enzima.

\subsubsection{Efecto de activadores e inhibidores}

Al igual que en el caso de las preparaciones crudas (Tabla 4.2.) la adición de EDTA, cisteína, cloruro de calcio, cloruro mercúrico e iodoacetato no modifican la actividad caseinolítica de la fracción III, en tanto que el PMSF produce una inhibición irreversible de la misma, confirmando que se trata de una proteinasa serínica que no es activada por la presencia de iones calcio. 


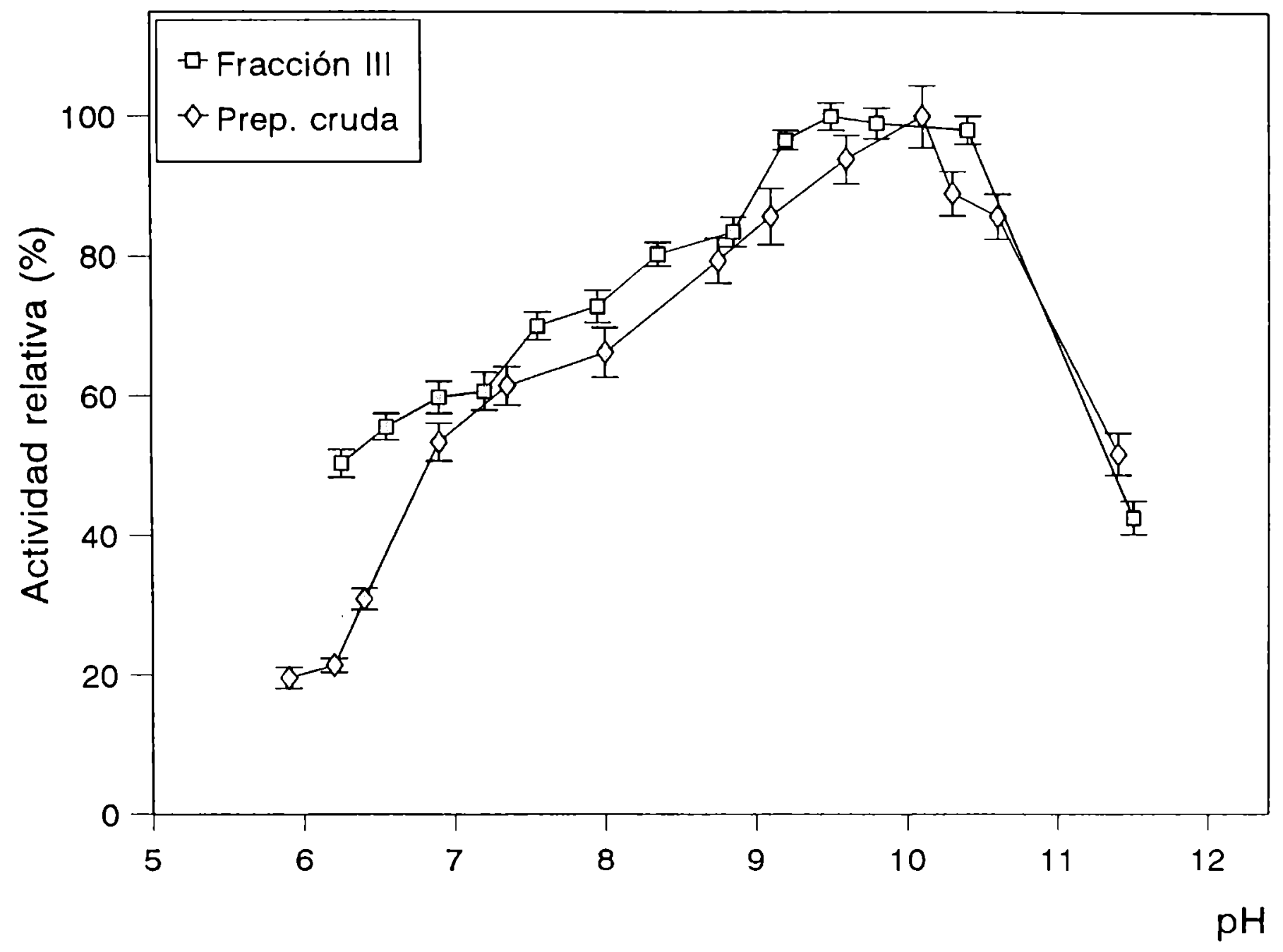

Figura 4.20. Efecto del pH sobre la actividad de la fracción III y de la preparación cruda frente a casefna. Los valores consignados corresponden al pH de las mezclas de reacción. Los datos para cada sustrato resultan de promediar dos ensayos independientes $(11=5)$. Las barras representan la desviación estándar de los promedios. 


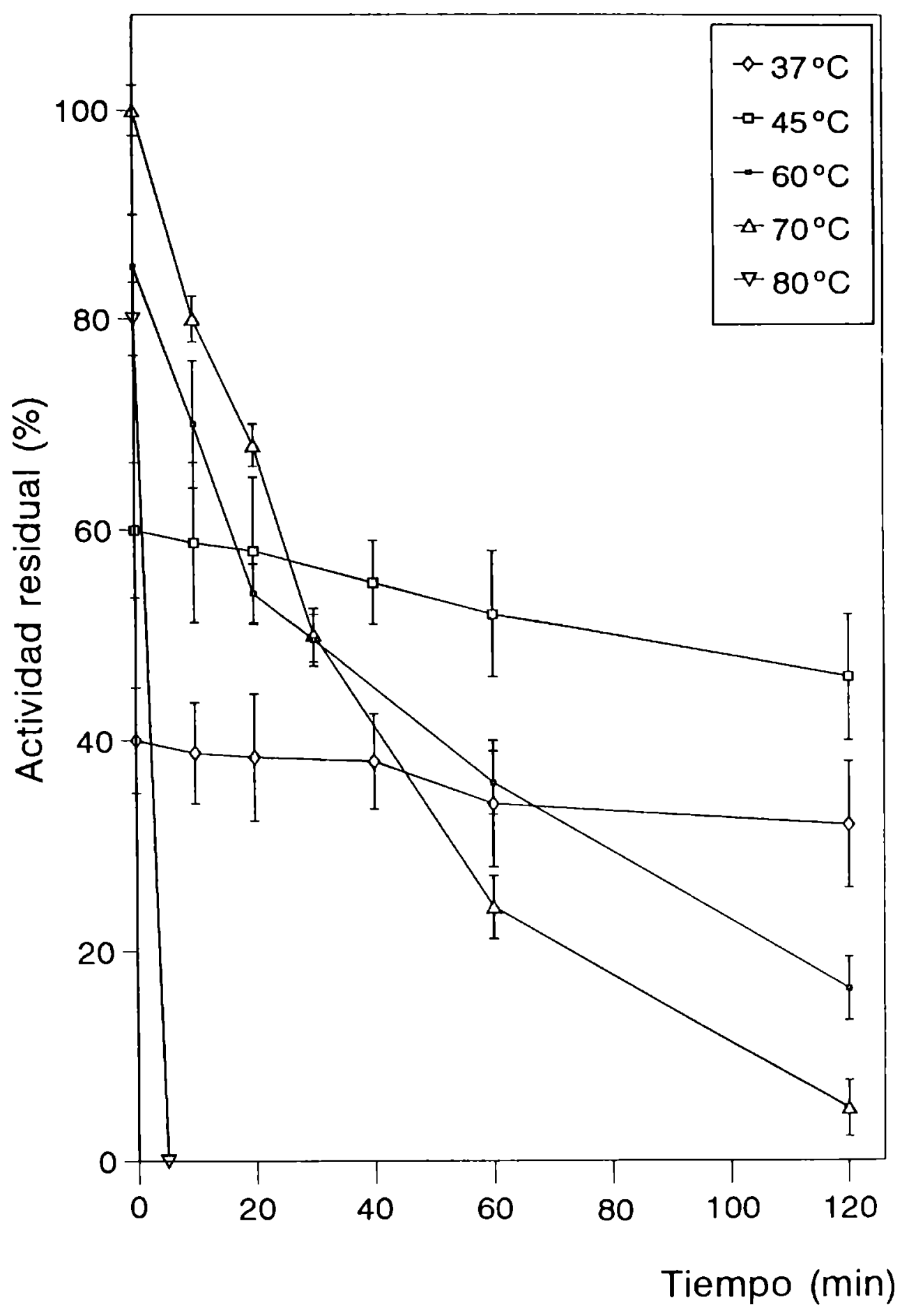

Figura 4.21. Efecto de diferentes tratamientos témicos sobre la actividad de la fracción III. Finalizado cada período de incubación se midió la actividad caseinolítica residual a cada una de las temperaturas ensayadas a pH 8,0 durante dos minutos. Los datos resultan de promediar dos ensayos independientes $(n=5)$. Las barras representan la desviación estándar de los promedios. 


\subsubsection{Ensayo de la actividad esterolítica con sustratos sintéticos}

Con el objeto de conocer el comportamiento de la fracción principal frente a los sustratos sintéticos ensayados con la preparación cruda (4.3.8.), se determinaron las velocidades de hidrólisis enzimática y no enzimática y en función de las mismas se calcularon las $U_{\mathrm{cbz}}$ para cada uno de los sustratos empleados.

La tabla 4.5. contiene los valores de la actividad específica de la fracción III sobre los $\mathrm{N}$-carbobenzoxi-p-nitrofeniléster derivados de aminoácidos: la actividad relativa mostró el mismo orden de prioridad que el obtenido con la preparación cruda, debiendo sin embargo destacarse que la preparación purificada muestra una mayor preferencia por el derivado de alanina que la fracción cruda. Las respectivas curvas de progreso de reacción se muestran en las figuras 4.22 a 4.24 .

\begin{tabular}{lccc}
\hline Aminoácido & $\begin{array}{c}\text { Actividad } \\
\mathrm{U}_{\mathrm{cbz}}\end{array}$ & $\begin{array}{c}\text { Actividad especifica } \\
\mathrm{U}_{\mathrm{cbz}} / \mathrm{mg}\end{array}$ & $\begin{array}{c}\text { \% Actividad } \\
\text { relativa }\end{array}$ \\
\hline & & & \\
Ala & $64,85 \pm 0,56$ & $13,80 \pm 0,12$ & 100 \\
Gly & $20,16 \pm 0,23$ & $4,31 \pm 0,05$ & 31 \\
Leu & $12,35 \pm 0,12$ & $2,62 \pm 0,03$ & 19 \\
Phe & $3,68 \pm 0,09$ & $0,81 \pm 0,02$ & 6 \\
Val & $2,18 \pm 0,30$ & $0,50 \pm 0,06$ & 3 \\
Trp & no detectable & & \\
Cys & no detectable & & \\
Tyr & no detectable & & \\
Lys & no detectable & & \\
Asn & no detectable & & \\
Asp & no detectable & &
\end{tabular}

Tabla 4.5. Actividad esterolítica de la fracción III.

\subsubsection{Zimograma de la fracción III}

En la fig. 4.25. pueden observarse el isoelectroforetograma y el respectivo zimograma de la fracción III, que confirma la presencia de actividad proteolítica en la misma. 


\begin{tabular}{lcc}
\hline Verlable & Value & Std. Err. \\
\hline $\begin{array}{l}\text { Gradient } \\
\text { Intercept }\end{array}$ & $7.34286 E-04$ & $1.03989 E-05$ \\
\hline & $2.57067 E-01$ & $1.21494 E-03$ \\
\hline
\end{tabular}

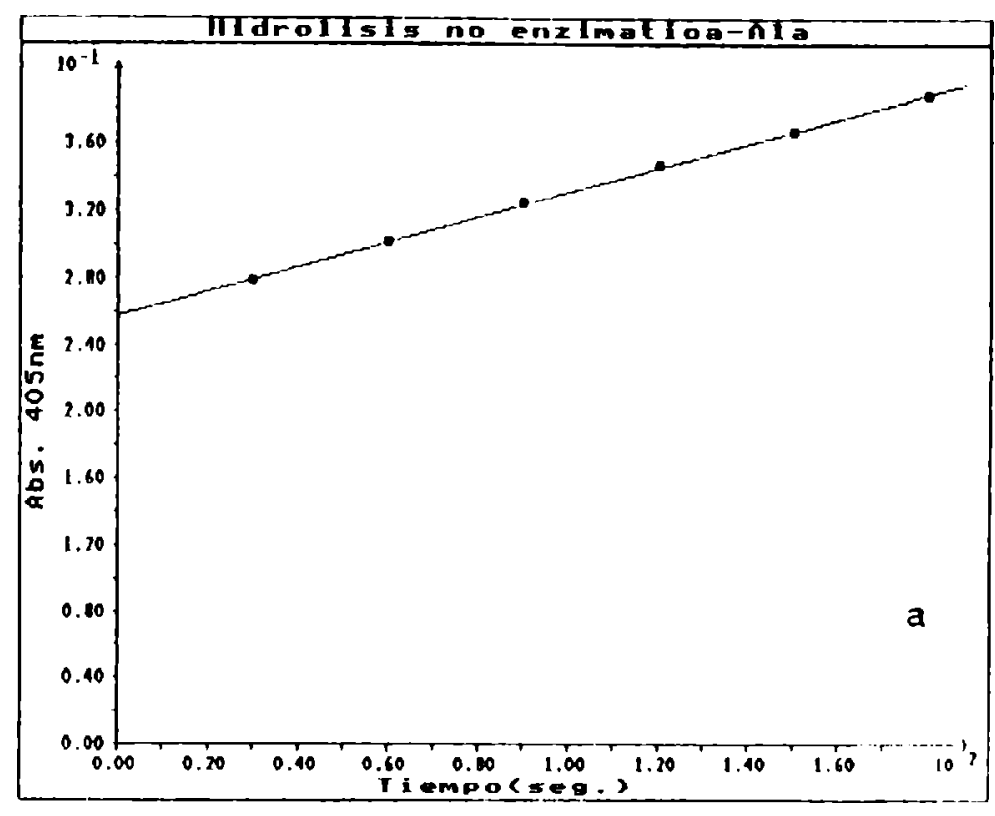

Linear Regresolon

Simple welghting

\begin{tabular}{lcc}
\hline Varlable & Value & Std. Err. \\
\hline Gradlent & $7.21905 \mathrm{E}-03$ & $5.51245 \mathrm{E}-05$ \\
Intorcopt & $5.39333 \mathrm{E}-01$ & $6.44038 \mathrm{E}-03$ \\
\hline
\end{tabular}

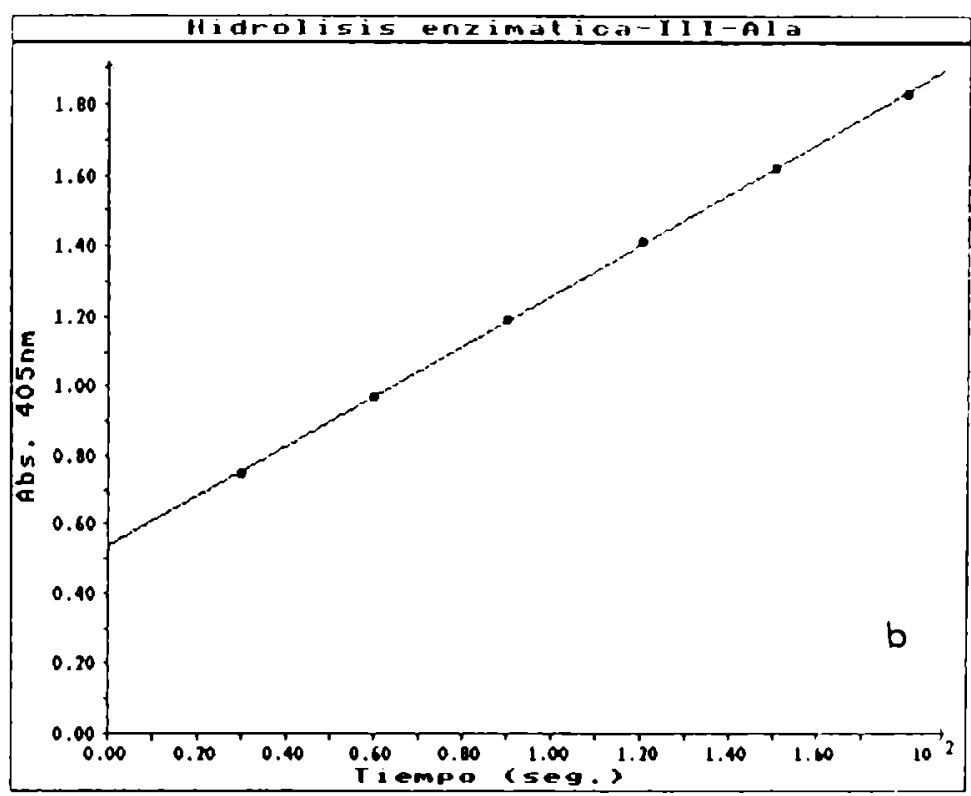

Figura 4.22. Curva de progreso de reacción sobre $N$-carbobenzoxi-L-alanina-pnitrofenilester. a: hidrólisis no enzimática; b: hidrólisis enzimática (fracción III). 


\begin{tabular}{lcc}
\hline Varlable & Value & Std. Err. \\
\hline $\begin{array}{l}\text { Gradient } \\
\text { Intercept }\end{array}$ & $\begin{array}{l}9.16667 E-04 \\
1.96700 E-01\end{array}$ & $\begin{array}{l}3.33167 E-06 \\
3.31497 E-04\end{array}$ \\
\hline
\end{tabular}

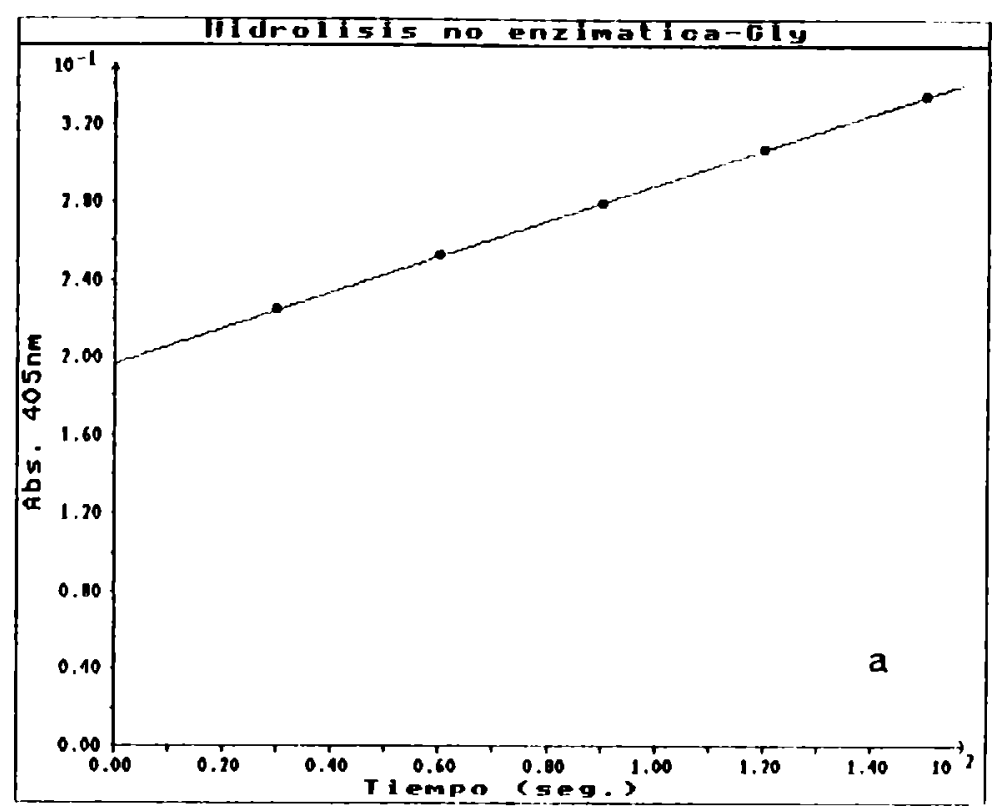

Linear Regreasion
Simple welghting

\begin{tabular}{lcc}
\hline Varlable & Value & Std. Err. \\
\hline Gradient & $2.93304 \mathrm{E}-03$ & $2.28294 \mathrm{E}-05$ \\
Intercopt & $3.77795 \mathrm{E}-01$ & $2.63813 \mathrm{E}-03$
\end{tabular}

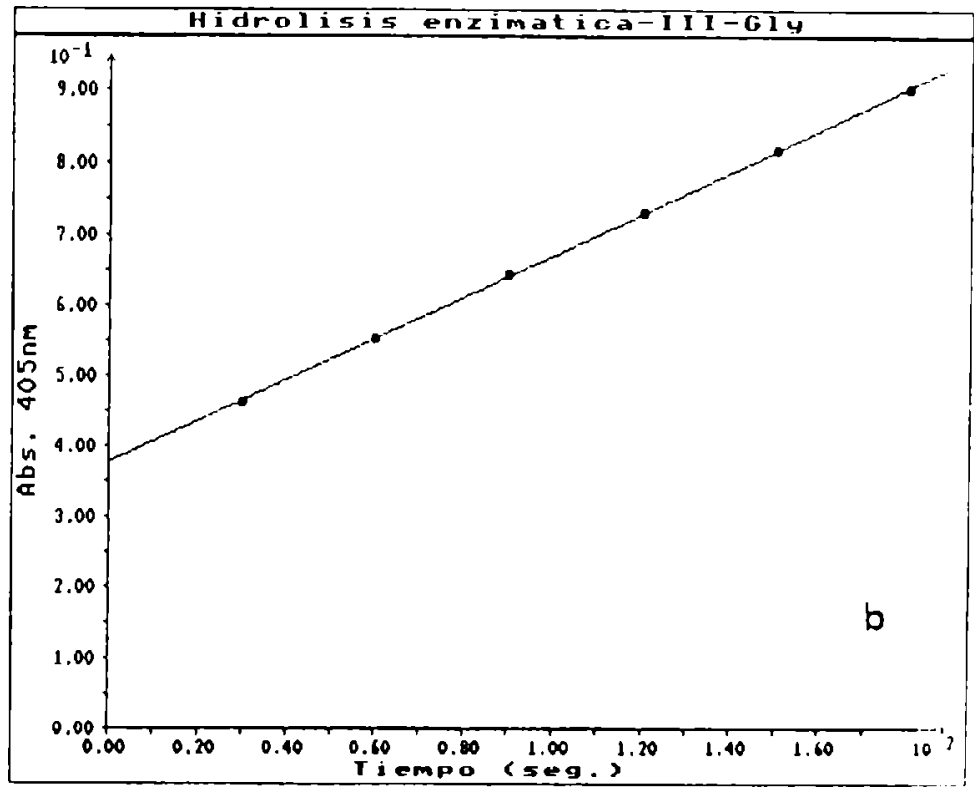

Figura 4.23. Curva de progreso de reacción sobre $N$-carbobenzoxi-glicina-pnitrofeniléster. a: hidrólisis no enzinática; b: hidrólisis enzinática (fracción III). 


\begin{tabular}{lll}
\hline Vorlable & Value & Std. Err. \\
\hline $\begin{array}{l}\text { Gradlent } \\
\text { Intercopt }\end{array}$ & $2.60571 E-04$ & $1.07410 E-05$ \\
& $5.61333 E-02$ & $1.25500 E-03$
\end{tabular}

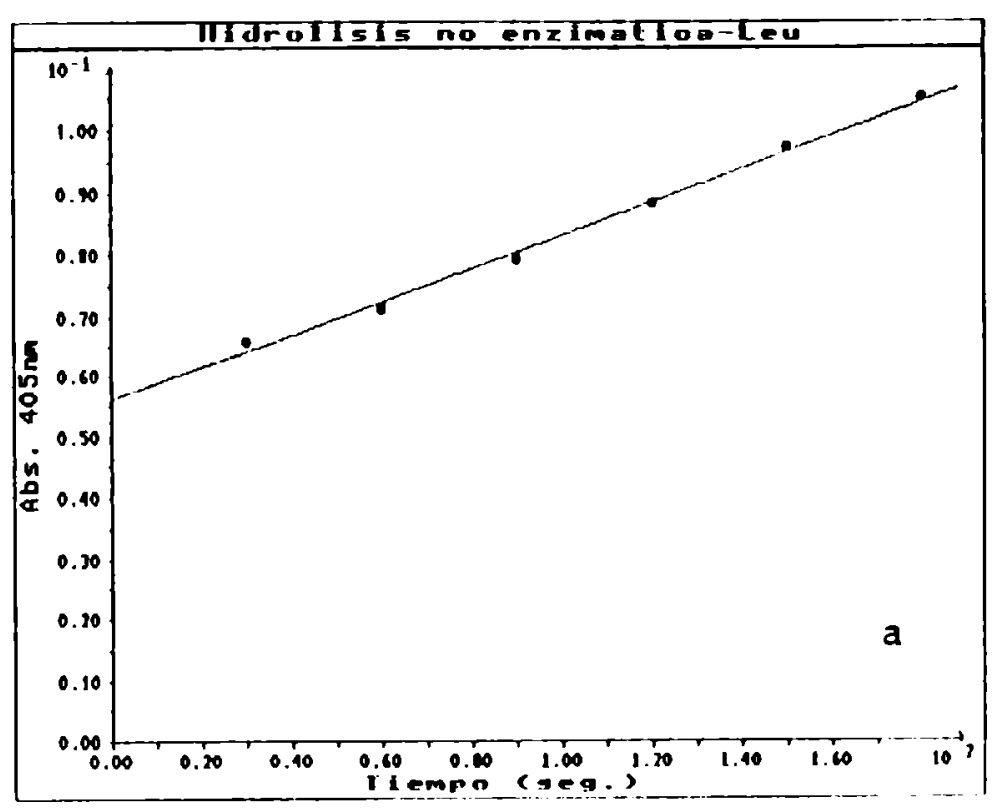

Linoar Rogreosion

Simple weighting

\begin{tabular}{lcc}
\hline Varlablo & Value & Std. Err. \\
\hline Gradient & $1.50378 E-03$ & $4.58323 E-06$ \\
Intorcopt & $1.23547 \mathrm{E}-01$ & $5.49710 \mathrm{E}-04$ \\
\hline
\end{tabular}

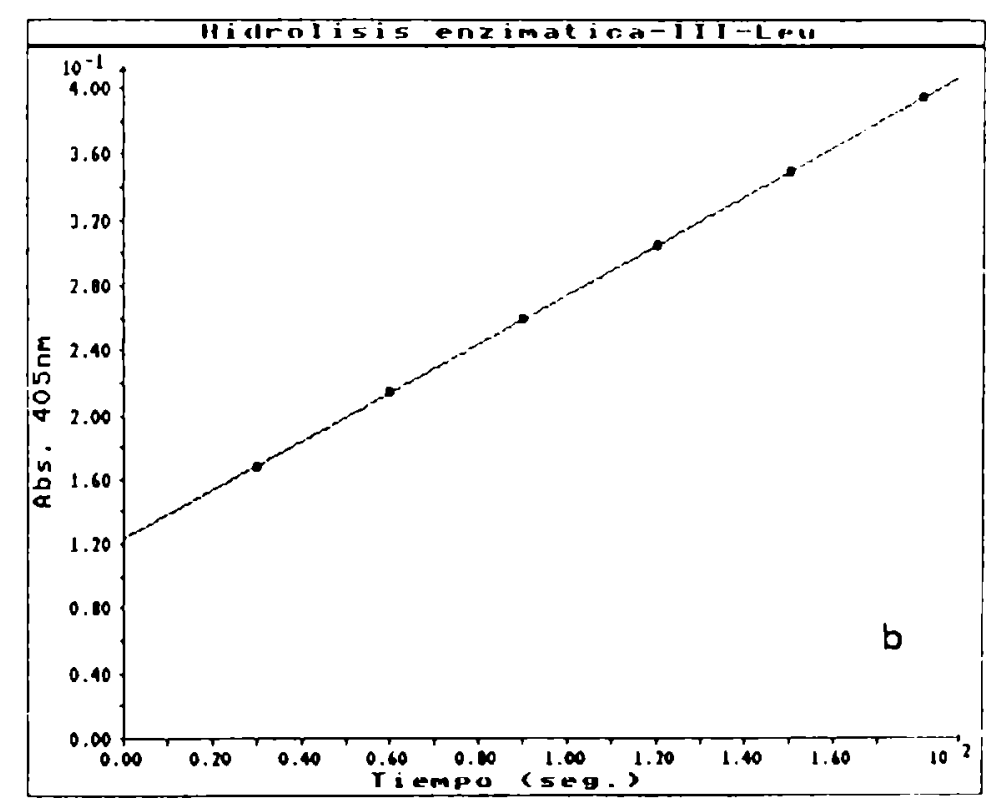

Figura 4.24. Curva de progreso de reacción sobre $N$-carbobenzoxi-L-leucina-pnitrofeniléster. a: hidrólisis no enzinática; b: hidrólisis enzinática (fracción III). 


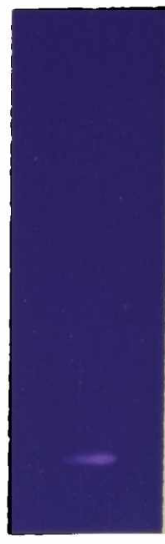

a

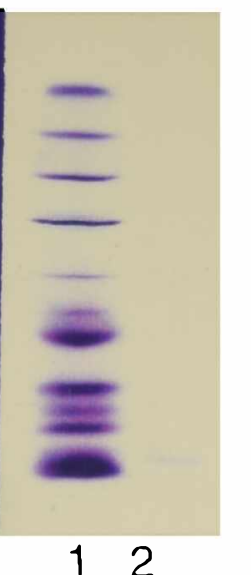

b
$-3.50$

$-5,20$

$-5,85$

- 6.55

- 6.85

$-8.15$

$\begin{array}{r}8.45 \\ \hline-65 \\ \hline\end{array}$

9.30

Figura 4.25. Zimograma obtenido a partir del isoelectroenfocpue de la fracción III a) Zimograma de la fracción III b) Isoelectroenfoque. Carril 1: patrones de pl: carril 2: fracción III. 


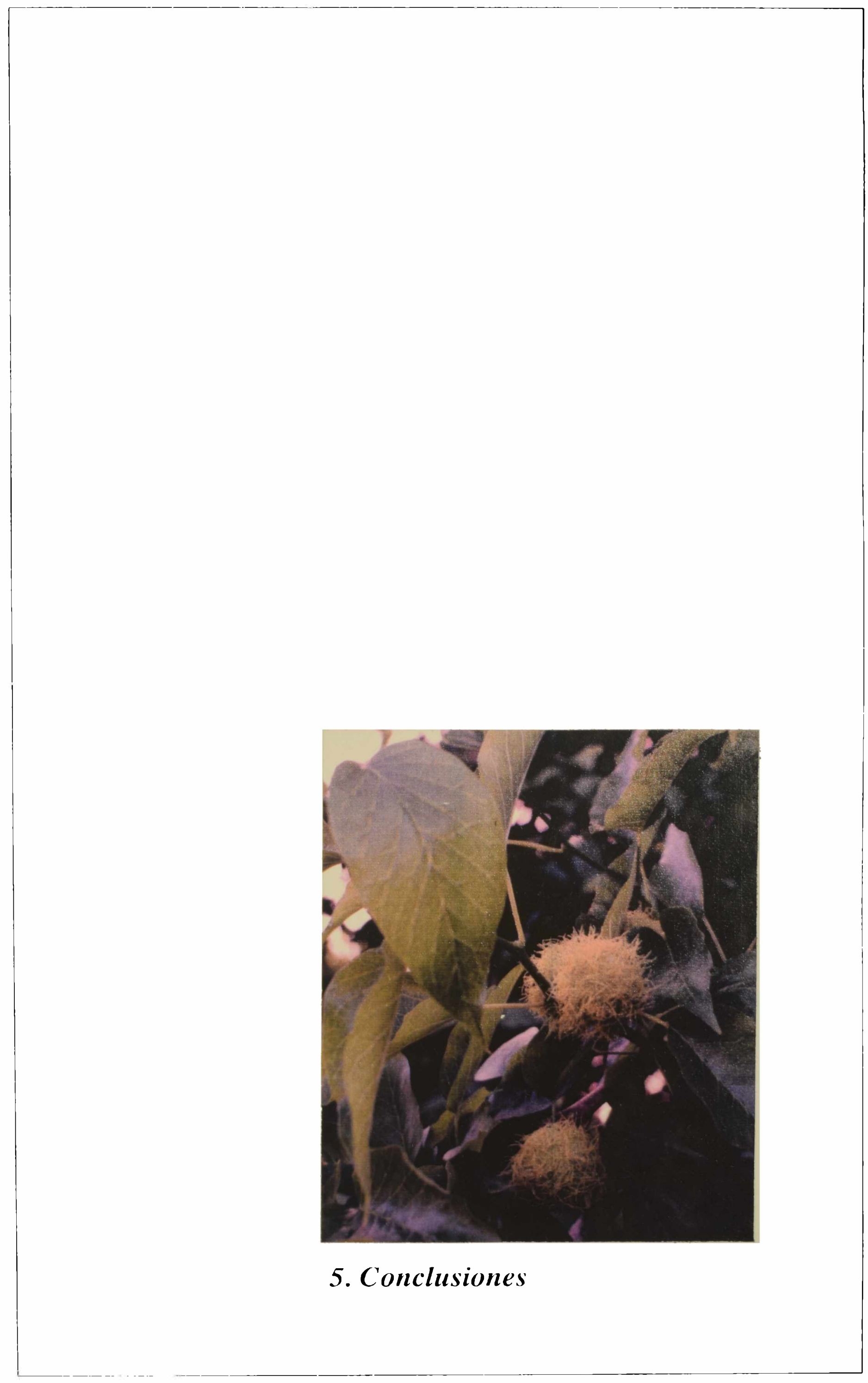


En el presente trabajo se han estudiado las proteasas contenidas en frutos maduros de Maclura pomifera (Raf.) Schneid. (Moraceae). El látex que producen los frutos de esta especie posee una importante actividad proteolítica, hecho que ya había sido descripto por Tauber (1949) en un estudio preliminar, quien propuso utilizar el nombre "pomiferina" para designar a las proteasas responsables de dicho comportamiento.

Existe una relación directa entre el grado de madurez de los frutos, la producción de látex y la actividad proteolítica específica del mismo, a diferencia de los resultados consignados en la bibliografía para Carica papaya (Skelton, 1969) y Pileus mexicanus (Soriano et al., 1975), donde el flujo de látex se reduce con la maduración y la actividad específica es independiente de ésta. En cuanto al rendimiento en látex de frutos maduros, los datos obtenidos exhiben la variabilidad esperable de muestras biológicas que se encuentran en un estado fisiológico equivalente, con valores que oscilan entre entre 0,39 y $0,78 \mathrm{ml}$ de látex por $100 \mathrm{~g}$ de frutos, con una media de $0,51 \mathrm{ml}$ de látex por $100 \mathrm{~g} \mathrm{de}$ frutos.

Siendo el criterio usual en la producción de enzimas de aplicación industrial el de contar con preparaciones del mínimo nivel de pureza compatible con las exigencias del proceso (Illanes, 1994), se juzgó oportuno determinar las condiciones de conservación y proceder a caracterizar las preparaciones crudas de pomiferina, para lo cual se ensayó su acción frente a sustratos naturales y sintéticos y se analizó su comportamiento en diferentes condiciones de $\mathrm{pH}$, fuerza iónica y temperatura, así como el efecto que ejercen una serie de activadores e inhibidores sobre la actividad proteolítica.

Las preparaciones crudas pueden conservarse congeladas a $-20^{\circ} \mathrm{C}$ durante períodos no demasiado prolongados, ya que se produce una disminución semanal de la actividad del orden del $0,6 \%$. Por el contrario, la liofilización demostró ser un procedimiento más adecuado para conservar preparaciones crudas de pomiferina, ya que la pérdida de la actividad enzimática luego de 6 meses de almacenamiento es sólo del $2 \%$.

Pomiferina demostró ser activa frente a los diversos sustratos proteicos ensayados (caseína, azocaseína, azocolágeno, hemoglobina desnaturalizada y proteínas de concentrados de soja). Las preparaciones crudas tienen una actividad específica frente a caseína que es aproximadamente el $65 \%$ de la que posee una preparación equivalente de ficina comercial ("ficin, tan powder", Sigma). Cuando se utiliza azocoll como sustrato, la 
actividad específica detectada representa el $41 \%$ de la comunicada para una muestra de la enzima cruda obtenida de la pulpa de frutos de Cucurbita ficifolia (Curotto et al., 1989).

En el caso de las proteínas de soja, cuyo empleo con fines alimentarios está limitado por sus deficitarias propiedades funcionales, la estrategia experimental adoptada fue la de ensayar conjuntamente la acción de pomiferina y de alcalasa sobre concentrados de soja, con el objeto de comparar cuali y cuantitativamente los productos de hidrólisis de ambas proteasas. El grado de hidrólisis logrado con pomiferina es del mismo orden que el producido por alcalasa, luego de tres horas en condiciones de $\mathrm{pH}$ óptimo. Sin embargo el análisis electroforético de los productos obtenidos a distintos tiempos muestra un patrón de hidrólisis diferencial para cada una de las enzimas utilizadas, lo que podría traducirse en distintas modificaciones de las propiedades funcionales.

Cuando las preparaciones crudas de pomiferina son ensayadas frente a $\mathrm{N}$ carbobenzoxi-p-nitrofenilésteres de aminoácidos, los resultados observados permiten inferir una preferencia de la enzima por uniones peptídicas en las que el aminoácido que aporta el grupo carboxilo sea de naturaleza no polar y/o de pequeño tamaño (alanina, glicina y leucina y en menor grado fenilalanina y valina, en ese orden).

La variación de la actividad de estas preparaciones en función del $\mathrm{pH}$ es similar a la que muestran la mayoría de las proteinasas serínicas, que poseen máxima actividad proteolítica a pH alcalino. A valores de pH entre 9,3 y 10,3 (caseína) y entre 8,2 y 9,3 (azocoll) la enzima manifiesta una actividad relativa superior al $90 \%$. Por otra parte, los ensayos de estabilidad en el rango de $\mathrm{pH}$ de mayor actividad indican que la enzima puede ser utilizada en estas condiciones al menos durante dos horas, prácticamente sin pérdida de actividad. Un aspecto a tener en cuenta es que si la concentración de sales presentes en el medio de reacción es igual o mayor a $0,2 \mathrm{M}$, la actividad enzimática disminuye notablemente.

El estudio de la estabilidad térmica de la preparación cruda demuestra que la enzima puede ser empleada casi sin pérdida de actividad durante al menos dos horas por debajo de $55^{\circ} \mathrm{C}$. No obstante, la enzima presenta una actividad sobresaliente durante los primeros 15 minutos a $70^{\circ} \mathrm{C}$, lo que también permite utilizarla en procesos breves que admitan la aplicación de temperaturas elevadas. 
Los resultados obtenidos al ensayar pomiferina frente a diferentes activadores e inhibidores permiten establecer que se trata de una fitoproteasa serínica cuya actividad es independiente de la presencia de iones calcio.

Las preparaciones crudas contienen pigmentos amarillos y un alto contenido de hidratos de carbono solubles que pueden eliminarse casi totalmente con el agregado de dos volúmenes de acetona, lo que constituye la primera etapa de purificación: el precipitado acetónico blanquecino así obtenido contiene solamente un $8 \%$ de los hidratos de carbono originales, reteniendo el $97 \%$ de la actividad inicial.

El ensayo de autodigestión a temperatura ambiente de los precipitados acetónicos redisueltos revela una suave caída de la actividad enzimática con el tiempo (25\% a las 24 horas), hecho que no se correlaciona con la notoria disminución de las fracciones activas que muestra el análisis por SDS-PAGE, lo que sugiere que muchos de los péptidos producidos por autohidrólisis son proteolíticamente activos.

La utilización de técnicas cromatográficas permite completar la purificación de pomiferina. El uso de un intercambiador aniónico (DEAE-Sepharose Fast Flow) posibilita la separación de dos fracciones activas minoritarias denominadas I $(71,2 \mathrm{kD}, \mathrm{pI} 6,2)$ y II $(62,7 \mathrm{kD}, \mathrm{pl} 4,3)$, en tanto que el pasaje de la fracción no retenida por un intercambiador catiónico (CM-Sepharose Fast Flow) permite separar dos fracciones activas principales denominadas III $(69,7 \mathrm{kD}$, pI 8,9$)$ y IV $(69,9 \mathrm{kD}$, pI 9,4). Las fracciones III y IV representan el $77 \%$ de la actividad recuperada y poseen las mayores actividades específicas $\left(9,44\right.$ y $10,58 \mathrm{U}_{\text {cas }} \cdot \mathrm{mg}^{-1}$, respectivamente). Por tratarse de la fracción purificada de mayor rendimiento $(17,8 \%)$, la fracción III fue sometida a una serie de ensayos tendientes a correlacionar su comportamiento con el de las preparaciones crudas: el perfil de actividad en función del pH (caseína) es sumamente similar, la estabilidad térmica muestra un deterioro importante por encima de los $60^{\circ} \mathrm{C}$, la adición de activadores e inhibidores ejerce el mismo efecto y la actividad relativa sobre los sustratos sintéticos mantiene el mismo orden, aún cuando se nota una mayor preferencia para el derivado de alanina que en las preparaciones crudas.

La información suministrada da cuenta de la existencia de una nueva proteasa vegetal que podría ser de utilidad en procesos industriales que requieran enzimas proteolíticas con elevada actividad a pH alcalino. Por otra parte, y en razón de la 
naturaleza del material vegetal (látex, en lugar de extracto de tejidos vegetales), las preparaciones "crudas" resultan de hecho un material bastante purificado, que podría ser ventajosamente utilizado como tal por la industria o -a lo sumo- luego de una simple precipitación con acetona. De requerirse una preparación enzimática de mayor pureza, es posible obtener un material parcialmente purificado con muy buen rendimiento y elevada actividad específica simplemente recolectando la fracción no retenida por cromatografía de intercambio aniónico del precipitado acetónico. 


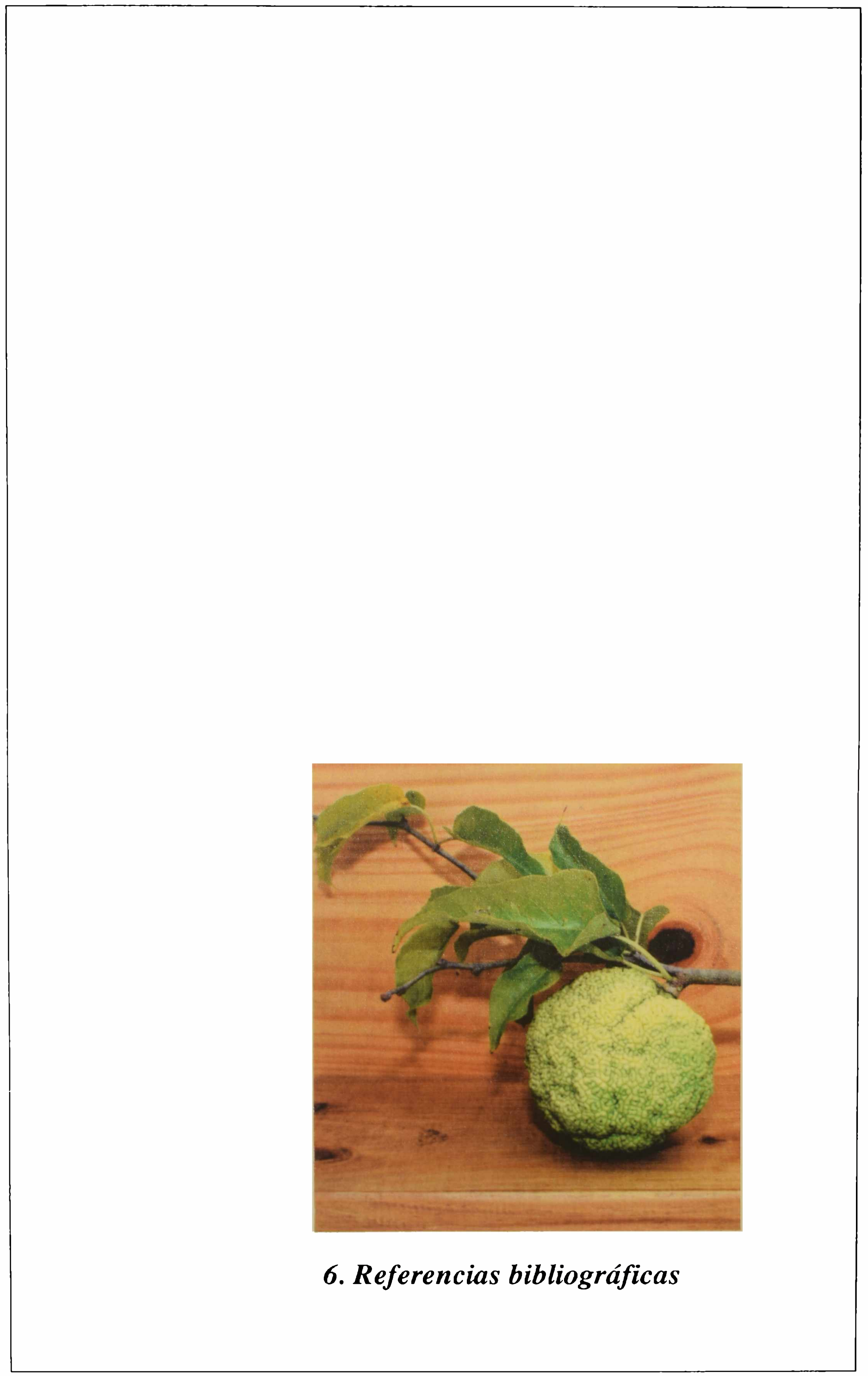


Abraham, K.I. \& P.N. Joshi (1979a) "Studies on proteinases from Calotropis gigantea latex. I. Purification and some properties of two proteinases containing carbohydrate", Biochim. Biophys. Acta 568: 111-9.

Abraham, K.I. \& P.N. Joshi (1979b) "Studies on proteinases from Calotropis gigantea latex. II. Physico-chemical properties of calotropain-FI and F-II", Biochim. Biophys. Acta 568: 120-6.

Adams, C.A. \& Rinne, R.W. (1981) "The ocurrence and significance of dispensable proteins in plants", New Phytol. 89: 1-6.

Adler-Nissen, J. (1986) "Enzymic hydrolysis of food proteins", Elsevier, London \& NY, pág. 122.

Anderson, J.W. (1968) "Extraction of enzymes and subcellular organelles from plant tissues" Phytochemistry 7: 1973-88.

Anson L. (1938) "The estimation of pepsin, tripsin, papain, and cathepsin with hemoglobin", J. Gen. Physiol. 22: 79-89.

Arnon, R. (1970) "Papain", Methods Enzymol, 19: 226-44.

Arzu, A., H. Mayorga, J. González \& C. Rolz (1972) "Wet concentration of protein in screw-press cotton seed cake", Agric. Food Chem. 20: 805-9.

Bailey, L.H. (1953). "The Standard Cyclopedia of Horticulture" The Macmillan Company, N.Y., Vol II, págs. 1961-2.

Baines, B.S. \& K. Brocklehurst (1982) "Characterization of papaya peptidase $A$ as a cysteine proteinase of Carica papaya $\mathrm{L}$. with active-centre properties that differ from those of papain by using 2,2'-dipyridyl disulphide and 4-chloro-7nitrobenzofurazan as reactivity probes", Biochem. J. 205: 205-211.

Barragán, B.E., M.T. Cruz, L. M. del Castillo \& M. Castañeda-Agulló (1985) "Proteinases of mexican plants. XI. Asclepain $\mathrm{g}$ from the latex of Asclepias glaucescens", Rev. Latinoamer. Quím. 16: 117-9.

Barrett, A.J. \& D.J. Buttle (1985) "Names and numbers of papaya proteinases", Biochem. J. 228: 527. 
Barrett, A.J. \& N.D. Rawlings (1991) "Types and families of endopeptidases", Biochem. Soc. Transact. 19: 707-15.

Barrett, A.J. (1986) "The classes of proteolytic enzymes" en "Plant Proteolytic Enzymes" (M.J. Dalling, ed.), CRC Press, Boca Raton, Florida, Vol. I, págs. 116.

Batkin, S., S.J. Taussing \& J. Szekerczes (1988a) "Modulation of pulmonary metastasis (Lewis lung carcinoma) by bromelain, an extract of pineapple stem (Ananas comosus)", Cancer Invest. 6: 241-42.

Batkin, S., S.J. Taussing \& J. Szekerczes (1988b) "Antimetastatic effect of bromelain with or without its proteolytic and anticoagulant activity", J. Cancer Res. Clin. Oncol. 114: 507-8.

Bazan, J.F. \& R.J. Fletterick (1988) "Viral cysteine proteases are homologous to the trypsin-like family of serine proteases: structural and functional implications". Proc. Natl. Acad. Sci. U.S.A. 85: 7872-6.

Bergmann, M. \& W.F. Ross (1936) "Proteolytic enzymes (VIII)", J. Biol. Chem. 114 717-26.

Bernardi, L.S., A.M.R. Pilosof \& G.B. Bartholomai (1991) "Enzymatic modification of soy protein concentrates by fungal and bacterial proteases", J. Amer. Oil Chem. Soc. 68: 102-5.

Bernhard, S.A. \& H. Gutfreund (1956) "Ficin-catalyzed reactions: the affinity of ficin for some arginine derivatives", Biochem. J. 63: 61-4.

Bernholdt, H.F. (1982) "The use of enzymes in the tenderization of meat", en "Use of enzymes in food technology" (P. Dupuy, ed.), Technique et Documentation Lavoisier, Paris, págs. 395-8.

Betzel, C., A.V. Teplyakov, E.H. Harutyunyan, W. Saenger \& K.S. Wilson (1990) "Thermitase and proteinase $\mathrm{K}$ : a comparison of the refined three-dimensional structures of the native enzymes", Protein Eng. 3: 161-72.

Blundell, T.L., B. T. Sewell \& A.D. McLachlan (1979) "Four-fold structural repeat in the acid proteases", Biochim. Biophys. Acta 580: 24-31. 
Boller, T. (1986) "Roles of proteolytic enzymes in interactions of plant with other organisms", en "Plant proteolytic enzymes" (M.J. Dalling, ed.), CRC Press, Boca Raton, Florida, Vol. I, págs. 68-96.

Bradford, M.B. (1976) "A rapid and sensitive method for the quantitation of micrograms quantities of protein utilizing the principle of protein-dye binding", Anal. Biochem. 72: 248-54.

Brenner, S. (1988) "The molecular evolution of genes and proteins: a tale of two serines", Nature 334: 528-30.

Brockbank, W.J. \& K.R. Lynn (1979) "Purification and preliminary characterization of two asclepains from the latex of Asclepias syriaca L. (milkweed)", Biochim. Biophys. Acta 578: 113-22.

Brocklehurst, K y E. Salih (1983) "Nomenclature of papaya proteinases", Biochem. J., 213: 559.

Brocklehurst, K., B.S. Baines \& M.P. Kierstan (1981) "Papain and other constituents of Carica papaya L.", Top. Enzyme Fermentation Biotechnol. 5: 262-335.

Brocklehurst, K., E. Salih, R. Mc Kee \& H. Smith (1985) "Fresh non-fruit latex of Carica papaya contains papain, multiple forms of chymopapain $\Lambda$ and papaya proteinase omega", Biochem. J. 228: 525-7.

Caldwell, F.C. \& F.L. Caldwell (1929) Am. J. Trop. Med. 9: 471 (citado por Robbins, 1934).

Carpenter, D.C. \& F.E. Lovelace (1943) "The isoelectric point of asclepain". J. Amer. Chem. Soc. 65: 2364-5.

Castañeda Agulló, M., F. Gavarrón \& M.R. Balcazar (1942) "A new protease from Pileus mexicanus", Science 96: 365.

Castañeda-Agullo, M., A. Hernández, F. Loaeza \& W. Salazar (1945) "Crystallization of mexicain", J. Biol. Chem. 159: 751.

Charney, J. \& R.M. Tomarelli (1947) "A colorimetric method for the determination of the proteolytic activity of duodenal juice", J. Biol. Chem. 171: 501-5. 
Cohen, W. (1958) "Characterization of Ficin", Nature 182: 659-60.

Cohen, L.W., V.M. Coghlan \& L.C. Dihel (1986) "Cloning and sequencing of papainencoding cDNA", Gene 48: 219-27.

Cohen, L.W., C. Fluharty \& L.C. Dihel (1990) "Synthesis of papain in Escherichia coli", Gene 88: 263-7.

Colman, P.M., J.N. Jansonius \& B.W. Matthews (1972) "The structure of thermolysin: an electron density map at $2.3 \AA$ resolution", J. Mol. Biol. 70: 701-24.

Cruz, M.T., M.C. Oliver, L.M. del Castillo \& M. Castañeda-Agulló (1974) "Proteinasas de plantas mexicanas. I. Determinación de pesos moleculares de proteinasas cisteínicas por concentración de grupos tioles", Rev. Latinoam. Quím. 5: 18-25.

Curotto, E., González, G., O'Reilly, S. \& G. Tapia (1989) "Isolation and partial caracterization of a protease from Cucurbita ficifolia", FEBS Lett. 243: 363-5.

Davies, D. R. (1990) "The structure and function of the aspartic proteinases", Ann. Rev. Biophys. Chem. 19: 189-215.

Dayhoff, M.O., W.C. Barker \& L.T. Hunt (1983) "Establishing homologies in protein sequences", Meth. Enzymol. 91: 524-45.

de Seidl, D. S. \& K. Gaede (1961) "Activation of hurain by bivalent iron", Nature 190: 1112.

Dev, I.K. \& P.H. Ray (1990) "Signal peptidases and signal peptide hydrolases", J. Bioenerg. Biomemb. 22: 271-90.

Dimitri, M.J. (1978) "Enciclopedia Argentina de Agricultura y Jardinería", Editorial Acme, Buenos Aires, Tomo I, págs. 324 y 327.

Drenth, J., K.H. Kalk \& H.M. Swen (1976) "Binding of chloromethyl ketone substrate analogs to crystalline papain", Biochemistry 15: 3731-8.

Dubois, M., K.A. Gilles, J.K. Hamilton, P.A. Rebers \& F. Smith (1956) "Colorometric method for determination of sugars and related substances", Anal. Chem. 28: 350-6. 
Dunn, B.M. (1989) "Determination of protease mechanism", en "Proteolytic enzymes, a practical approach" (R.J. Beynon y J.S. Bond, eds.), IRL Press, Oxford, págs. 57-81.

Englund, P.T., T.P. King, L. C. Craig \& A. Walti (1968) "Studies on Ficin I. Its isolation and characterization", Biochemistry 7: 163-75.

Fersht, A.R., D.M. Blow \& J. Fastrez (1973) "Leaving group specificity in the chymotrysin-catalized hydrolysis of peptides. Sterochemical interpretation", Biochemistry 12: 2035-41.

Folin O. \& V. Ciocalteau (1927) "On tyrosine and tryptophane determinations in proteins", J. Biol. Chem. 73: 627-50.

Fox, P.F. (1982) "Exogenous enzymes in dairy technology", en "Use of enzymes in food technology" (P. Dupuy, ed.), Technique et Documentation Lavoisier, Paris, págs. 135-56.

Friedenson, B. (1970) "Multiple forms of ficin and their characterization", Fed. Proc. (54th Annual Meeting Fed. Am. Soc. Exp. Biol.) 29: 879 Abs.

Friedenson, B. \& I.E. Liener (1974) "Evidence that ficin is a glycoprotein", Biochim. Biophys. Acta 342: 209-12.

Fruton, J.S. (1976) "The mechanism of the catalytic action of pepsin and related acid proteinases", Adv. Enzymol. 44: 1-36.

Fusek, M., X. Lin \& J. Tang (1990) "Enzymic properties of thermopsin", J. Biol. Chem. 265: $1496-501$.

Gilles, A.M., A. De Wolf \& B. Keil (1983) "Amino acid sequences of the active-site sulfhydryl peptide and other thiol peptides from the cysteine proteinase $\alpha$ clostripain", Eur. J. Biochem. 130: 473-9.

Glazer, A.N. \& E.L. Smith (1971) "Papain and other plant proteolytic enzymes", en "The enzymes" (P.D. Boyer, ed.), Academic Press, New York, vol. III, pág. 501.

Gleisner, J.M. \& I.E. Liener (1973) "Chemical modification of the histidine residue located at the active site of ficin", Biochim. Biophys. Acta 317: 482-91. 
Glick, B.R. \& L.J. Brubacher (1977) "The chemical and kinetic consequences of the modification of papain by N-bromosuvvinimide", Can. J. Biochem. 5: 424-32.

Good, N.E. \& S. Izawa (1972) "Hydrogen ion buffers", Meth. Enzymol. 24: 53-68.

Goodenough, P.W. \& J. Owen (1987), "Chromatographic and electrophoretic analysis of papaya proteinases", Phytochemistry 26: 75-9.

Grassman, W. \& H. Dyckerhoff (1928) "Plant proteases (X). Action of yeast polypeptidase", Hope-Seyler's Z. Physiol. Chem. 179: 41-78.

Green, D. \& M. Rivetna (1992) "Substrate specificity of human renin: the effect of substitutions at the amino terminus and P3 position of the substrate", en "Structure and function of aspartic proteinases. Genetics, structure, and mechanisms" (B. Dunn, ed. ), Plenum Press, New York/London, págs. 383-6.

Greenberg, D.M. \& Theodore Winnick (1940) "Plant proteases. II. pH-activity curves", J. Biol. Chem. 135: 775-80.

Hames, B.D. (1981) "An introduction to polyacrylamide gel electrophoresis" en "Gel electrophoresis of proteins. A practical aproach" (D. Hames \& D. Rickwood, eds.), IRL Press Ltd, London, págs. 1-86.

Hartley, B.S. (1960) "Proteolytic enzymes", Ann. Rev. Biochem. 29: 45-72.

Heinicke y Gortner (1957) "Stem bromelain. A new protease preparation from pineapple plants", Econ. Bot. 11: 225-34.

Hofmann T., B.M. Dunn \& A.L. Fink (1984) "Cryoenzymology of penicillopepsin. Appendix: Mechanism of Action of Aspartyl Proteinases", Biochemistry 23: 5247-56.

Houde, A. \& J.M. Weber (1990) Gene 88: 269-73 (citado por Barret \& Rawlings, 1991).

Husain, S.S. \& G. Lowe (1968) "Evidence for histidine in the active sites of Ficin and Stem bromelain", Biochem. J. 110: 53-7. 
Husain, S.S. \& G. Lowe (1970a) "The amino acid sequence around the active-site cysteine and histidine residues, and the buried cysteine residue in Ficin", Biochem. J. 117: 333-40.

Husain, S.S. \& G. Lowe (1970b) "A reinvestigation of residues 64-68 and 175 in papain. Evidence that residues 64 and 175 are asparagine", Biochem. J. 116: 689-92.

Illanes, A. (1994) "Biotecnología de enzimas", Secretaría General de la OEA, Programa Regional de Desarrollo Científico y Tecnológico, Serie de Biología, Monografía $N^{0} 35$, Ediciones Universitarias de Valparaíso de la Universidad Católica de Valparaíso, Chile, pág. 45.

Inei-Shizukawa, G., M.C. Oliver, M.T. Cruz, L.M. del Castillo \& M. Castañeda-Agulló (1976) "Proteinasas de plantas mexicanas. V. Investigaciones acerca de la actividad de la mexicaína y la hemisfericina", Rev. Latinoam. Quím. 7: 131-6.

Jaffé, W.G. (1943) "Hurain, a new plant protease from Hura crepitans", J. Biol. Chem. 149: $1-7$.

Jaffé, W.G. \& D.S. de Seidl (1960) "Über die Hemmung von Hurain, einer pflanzlichen protease, durch trypsininhibitoren", Experientia 16: 505-8.

James, M. N. G. \& A. R. Sielecki (1987) "Aspartic proteinases and their catalytic pathway", en "Biological macromolecules and assemblies. Vol. 3: Active sites of enzymes" (F. A. Jurnak \& A. McPherson, eds.), John Wiley \& Sons, New York, págs. 413-82.

Jiang, W. \& J.S. Bond (1992) "Families of metalloendopeptidases and their relationships", FEBS Lett. 312: 110-14.

Jones, I.K. \& A.N. Glazer (1970) "Comparative studies on four sulfhydryl endopeptidases ("ficins") of Ficus glabrata latex", J. Biol. Chem. 245: 2765-72.

Jost, R. \& J.C. Monti (1977) "Partial enzymic hydrolysis of whey protein by trypsin", J. Dairy Sci. 6: 1387-93.

Kamphuis, I.G., K.H. Kalk, M.B.A. Swarte \& J. Drenth (1984) "Structure of papain refined at $1.65 \AA$ resolution", J. Mol. Biol. 179: 233-56. 
Kang, C.K. (1978) "Encyclopedia of Food Science" (M.S. Peterson y A.H. Johnson, eds.), The Avi Publishing Co. Inc., Westport, pág. 598.

Keller, B. \& T.A. Bickler (1986) Gene 49: 245-52 (citado por Barrett \& Rawlings, 1991).

Khan, I.U. \& L. Polgar (1983) "Purification and characterization of a novel proteinase, chymopapain S", Biochim. Biophys. Acta 760: 350-56.

Kilara, A. (1985) "Enzyme-modified protein food ingredients", Process Biochem. 20: 149-57.

Kim, S.Y., P.S.W. Park \& K.C. Rhee (1990) "Functional propertics of proteolytic enzymes modified soy protein isolate", J. Agric. Food Chem. 38: 651-6.

Kimmel, J.R. \& E.L. Smith (1957) "The properties of papain", Adv. Enzymol., 19: 267334.

Kito, K. \& T. Murachi (1969) "Valylprolylarginine: a ninhidrin negative tripeptide", $J$. Chromatogr. 44: 205-7.

Kortt, A.A. \& T.Y. Liu (1973) "On the mechanism of action of Streptococcal proteinase. II Comparison of the kinetics of proteinase and papain-catalyzed hydrolysis of $\mathrm{N}$ Acylamino acid esters", Biochemistry 12: 328-37.

Kortt, A.A., S. Hamilton, E.C. Webb \& B. Zerner (1974a) "Ficins (EC 4.22.3.). Purification and characterization of the enzymatic componentes of the latex of Ficus glabrata", Biochemistry 13: 2023-8.

Kortt, A.A., J.A. Hinds \& B. Zerner (1974b) "On the specificity and pH dependence of ficin-catalyzed hydrolyses. Some comparisons with bromelain specificity", Biochemistry 13: 2029-37.

Kramer, D.E. \& J.R. Whitaker (1964) "Ficus enzymes II. Properties of the proteolytic enzymes of Ficus carica variety Kadota", J. Biol. 239: 2178-83.

Kramer, D.A. \& J.R. Whitaker (1969a) "Multiple molecular forms of ficin. Evidence against autolisis as explanation", Plant Physiol. 44: 1560-5. 
Kramer, D.A. \& J.R. Whitaker (1969b) "Nature of the conversion of Ficus carica variety Kadota ficin component D to C. Some physico-chemical properties of components C and D", Plant Physiol. 44: 1566-73.

Kunimitsu, D.K. \& K.T. Yasunobu (1970) "Chymopapain B", Meth. Enzymol. 19: 24452.

Kuo, W.L., B.D. Gehm \& M.R. Rosner (1990) "Cloning and expression of the cDNA for a Drosophila insulin-degrading enzyme", Mol. Endocrinol. 4: 1580-91.

Laemmli, U.K. (1970) "Cleavage of structural proteins during the assembly of the head of bacteriophage T4", Nature 227: 680-5.

Lennox, F.G. \& W.J. Ellis (1945) "Euphorbain, a protease occurring in the latex of the weed Euphorbia lathyris", Biochem. J. 39: 465.

Li, S.L., S. Norioka \& F. Sakiyama (1990) "Molecular cloning and nucleotide sequence of the beta-lytic protease gene from Achromobacter lyticus", J. Bacteriol. 172: 6506-11.

Liener, I.E. (1961) "A study of the number and reactivity of the sulfhydryl groups of ficin", Biochim. Biophys. Acta 53: 332-42.

Liener, I.E. \& B.Friedenson (1970) "Ficin", Meth. Enzymol., 19: 261-73.

Light, A., R. Frater, J.R. Kimmel \& E.L. Smith (1964)"Current-status of the structure of papain: the linear sequence, active sulfhydryl group and the disulfide bridges", Proc. Natl. Acad. Sci. U.S. 52: 1276-83.

Loomis, W.D. \& J. Battaile (1966) "Plant phenolic compounds and the isolation of plant enzymes", Phytochemistry 5: 423-38.

Lowe, G. (1976) "The cysteine proteinases", Tetrahedron 32: 291-302.

Lowry, O.H., N.J. Rosebrough, A. Lewis Farr \& R.J. Randall (1951) "Protein measurement with the Folin phenol reagent", J. Biol. Chem. 193: 265-75.

Lynn, K.R. (1983) "Definition of the site of reactivity of the ancestral protease of the papain type", Phytochemistry, 22: 2845-7. 
Lynn, K.R. \& N.A. Clevette-Radford (1985) "Ficine E, a serine protease from Ficus elastica", Phytochemistry 25: 1559-61.

Lynn, K.R. \& N.A. Clevette-Radford (1988) "Proteases of Euphorbiaceae", Phytochemistry 27: 45-50.

Lynn, K.R. \& M. Yaguchi (1979) "N-Terminal homology in three cysteinyl proteinases from Papaya latex", Biochim. Biophys. Acta 581 : 363-4.

Lynn, K.R., W.J. Brockbank \& N.A. Clevette-Radford (1980) "Multiple forms of the asclepains, cisteinyl proteases from milkweed", Biochim. Biophys. Acta 612: $119-25$.

Malthouse, J.P.G. \& K. Brocklehurst (1976) "Preparation of fully active ficin from Ficus glabrata by covalent chromatography and characterization of its active centre by using 2,2'-dipyridyl disulphide as a rectivity probe", Biochem. J. 159: 221-34.

Mantell, S.H., J.A. Matthews \& R.A. McKee (1985) "Principles of plant biotechnology", Blackwell Sci. Pub., London, págs. 211-2.

Marini-Bettolo, G.B., P.U. Angeletti, M.L. Salvi, L. Tentori \& G. Vivaldi (1963) "Ficin (I)", Gazz. Chim. Ital. 93: 1239-51.

Matthews, B.W. (1988) "Structural basis of the action of Thermolysin and related zinc peptidases", Acc. Chem. Res. 21: 333-40.

Maurer, H.R., M. Hozumi, Y. Honma \& J. Okabe-Kado (1988) "Bromelain induces the differentiation of leukemic cells in vitro: an explanation for its citostatic effects?", Planta Medica 1988: 377-80.

Mc Donald, J. (1985) "An overview of protease specificity and catalytic mechanisms: aspects related to nomenclature and classification", Histochem. J. 17: 773-85.

Metrione, R.M., R.B. Johnston \& R. Seng (1967) "Purification, partial characterization and sequence around a reactive sulfhydryl of ficin", Arch. Biochem. Biophys. 122: $137-43$.

Moehle, C.M., R. Tizard, S.K. Lemmon, J. Smart \& E.W. Jones (1987) "Protease B of the lysosomelike vacuole of the yeast Saccharomices cerevisiae is homologous to the subtilisin family of serine proteases", Mol. Cell Biol. 7: 4390-9. 
Netti, C., G.L. Bandi \& A. Pecielle (1972) "Anti-inflammatory action of proteolytic enzymes of animal, vegetable or bacterial origin administred orally compared with that of known anti-phlogistic compounds", Il Farmaco (Ed. Pr.) 27: 453-66.

Nomenclature Committee of the International Union of Biochemistry (1984) Enzyme Nomenclature 1984. Academic Press, New York-London, págs. 330-66.

North, M.J. (1982) "Comparative biochemistry of the proteinases of eukaryotic microorganisms", Microbiol. Rev. 46: 308-40.

Oda, K., T. Nakazima, T. Terashita, K.I. Suzuki \& S. Murao (1987) "Purification and properties of an S-PI (pepstatin Ac) insensitive carboxyl proteinase from Xanthomonas sp. bacterium", Agric. Biol. Chem. 51: 3073-80.

Ohno, S., Y. Emori, S. Imajoh, H. Kawasaki, M. Kisaragi \& K. Suzuki (1984) "Evolutionary origin of a calcium-dependent protease by fusion of genes for a thiol protease and a calcium-binding protein?", Nature (London) 312: 566-70.

O'Reilly, S., E. Curotto \& G. González (1981) "An evaluation of the azocoll colorimetric assay for quantitating proteolytic enzymes", Acta Cient. Venezolana 32: 105-8.

Pal, G. \& N.K. Sinha (1980) "Isolation, crystallization, and properties of calotropins DI and DII from Calotropis gigantea", Arch. Biochem. Biophys. 202: 321-9.

Pearl, L.H. (1987) "Hypothesis. The catalytic mechanism of aspartic proteinases", FEBS Lett. 214: 8-12.

Peterson, G.L. (1979) "Review of the Folin phenol protein quantitation method of Lowry, Rosebrough, Farr and Randall", Anal. Biochem. 100: 201-20.

Pickersgill, R.W., P. Rizkallah, G.W. Harris \& P.W. Goodenough (1991) "Determination of the estructure of papaya pepetidasa omega", Acta Cryst. B 47: 766-71.

Priolo, N.S., L.M.I. López, M.C. Arribére, C.L. Natalucci and N.O. Caffini (1991) "New purified plant proteinases for the food industry", Acta Alimentaria (Budapest) 20: 189-96. 
Polgar, L. \& P. Halasz (1982) "Current problems in mechanistic studies of serine and cysteine proteinases", Biochem. J. 207: 1-10.

Puski, G. (1975) "Modification of functional properties of soy proteins by proteolytic enzyme treatment", Cereal Chem. 52: 655-64.

Ramshaw, J.A. (1982) "Structures of plant proteins", Encycl. Plant Physiol., New Ser. 14A, 229.

Rennex, D., B.A. Hemmings, J. Hofsteenge \& S.R. Stone (1991) "cDNA cloning of porcine brain prolyl endopeptidase and identification of the active-site seryl residue", Biochemistry 30: 2195-203.

Revell, D.F., N.J. Cummings, K.C. Baker, M.E. Collins, M.A.J. Taylor, I.G. Summer, R.W. Pickersgill, I.F. Connerton \& P.W. Goodenough (1993) "Nucleotide sequence and expression in Escherichia coli of cDNAs encoding papaya proteinase omega from Carica papaya", Gene 127: 221-5.

Rivett, A.J. (1989) "The multicatalytic proteinase. Multiple proteolytic activities", Arch. Biochem. Biophys. 268: 1-8.

Robbins, B.H. (1930) "A proteolitic enzyme in ficin, the antihelmintic principle of leche de higueron", J. Biol. Chem. 87: 251-7.

Robbins, B.H. \& P.D. Lamson (1934) "Further studies on the proteolytic enzyme content of latex from the fig and related trees", J. Biol. Chem. 106: 725-8.

Robinson, G. W. (1975) "Isolation and characterization of papaya peptidase A from commercial chymopapain", Biochemistry 14: 3695-700.

Salvesen, G. \& H. Nagase (1989) "Inhibition of proteolytic enzymes", en "Proteolytic enzymes, a practical approach" (R.J. Beynon \& J.S. Bond, eds.), IRL Press at Oxford University Press, Oxford, págs. 83-104.

Sarath, G., R. S. de la Motte \& F. Wagner (1989) "Protease assay mehtods", en "Proteolytic enzymes, a practical approach" (R.J. Beynon \& J.S. Bond, eds.), IRL Press, Oxford, pág. 27.

Schecter, I. \& A. Berger (1967) "On the size of the active site in proteases. I. Papain", Biochim. Biophys. Res. Commun. 27: 157-62. 
Scocca, J. \& Y.C. Lee (1969) "The composition and structure of carbohidrate of pineaple stem bromelain", J. Biol. Chem. 244: 4852-63.

Scopes, R.K. (1984) "Protein purification. Principles and practice", Springer-Verlag, N.Y., pág. 219.

Sekul, A.A. \& R.L. Ory (1977) "Rapid enzymic method for partial hydrolysis of oilseed proteins for food uses", J. Amer. Oil Chem. Soc. 54: 32-5.

Sgarbieri, V.C., S.M. Gupte, D.E. Kramer \& J.R. Whitaker (1964) "Ficus enzymes. I. Separation of the proteolytic enzymes of Ficus carica and Ficus glabrata latices", J. Biol. Chem. 239: 2170-7.

Sicard, P. (1982) "Applications industrielles des enzymes", en "Les enzymes. Productions et utilizations industrielles" (G. Durand y P. Monsan, eds.), Gauthier-Villars, Paris, págs. 121-64.

Siffert, O., I. Emod \& B. Keil (1976) "Interaction of clostripain with natural trypsin inhibitors and its affinity habeling by $\mathrm{N} \alpha$-p-nitrobenzyloxycarbonil arginine chlormethylketone", FEBS Lett. 66: 114-9.

Skelton, G.S. (1969) "Development of proteolytic enzymes in growing papaya fruit", Phytochemistry 8: 57-60.

Soriano, M., M.T. Cruz, Y. Bustamante, L.M. del Castillo \& M. Castañeda-Agulló (1975) "Proteinasas de plantas mexicanas. III. Mexicaína: separación y caracterización", Rev. Latinoam. Quím. 6: 143-51.

Sugimura, K. \& T. Nishihara (1988) "Purification, characterization and primary structure of Escherichia coli Protease VII with specificity for paired basic residues: identity of protease VII and OmpT", J. Bacteriol. 170: 5625-32.

Sugiura, M. \& M. Sasaki (1974) "Studies on proteinases from Ficus carica var. Horaishi. V. Purification and properties of a sugar-containing proteinase (Ficin S)", Biochim. Biophys. Acta 350: 38-47.

Syu, W.J., S.H. Wu \& K.T. Wang (1983) "Purification of papain by affinity chromatography", J. Chromatogr. 262: 346-51. 
Szecsi, P. B. (1992) "The aspartic proteases", Scand. J. Clin. Lab. Invest. 52: 5-22.

Tablero, M., R. Arreguin, B. Arreguin, M. Soriano, R. I. Sánchez, A. Rodríguez Romero \& A. Hernández-Arana (1991) "Purification and characterization of multiple forms of asclepain g from Asclepias glaucescens H.B.K.", Plant Sci. 74: 7-15.

Tai, J.Y., A.A. Kortt, T.Y. Liu \& S.D. Elliott (1976) "Primary structure of streptococcal proteinase. III. Isolation of cyanogen bromide peptides: complete covalent structure of the polypeptide chain", J. Biol. Chem. 251: 1955-9.

Tang, J., M.N.G. James, I.N. Hsu, JH.A. Jenkins \& T.L. Blundell (1978) "Structural evidence for gene duplication in the evolution of the acid proteases", Nature (London) 271: 618-21.

Tang, J., P. Sepulveda, J. Marciniszyn, K.C.S. Chen, W.I. Huang, N. Tao, D. Liu \& J.P. Lanier (1973) "Amino-acid sequence of porcine pepsin", Proc. Natl. Acad. Sci. U.S.A. 70: 3437-9.

Tauber, H. (1949) "The chemistry and technology of enzymes", J. Wiley \& Sons, N.Y., pág. 171.

Tookey, H.L. \& H.S. Gentry (1969) "Proteinase of Jarilla chocola, a relative of papaya", Phytochemistry 8: 989-91.

Tsuru, D., S. Shimada, S. Maruta, T. Yoshimoto, K. Oda, S. Murao, T. Miyata \& S. Iwanaga (1986) "Isolation and aminoacid sequence of a peptide containing an epoxide-reactive residue from the thermolysin-digest of Scytalidium lignicolum acid protease B", J. Biochem. (Tokyo), 99: 1537-9.

Umezawa, H. (1976) "Structures and activities of protease inhibitors of microbial origin", Meth. Enzymol. 45: 678-95.

Vernet, T., J. Chatellier, D.C. Tessier \& D.Y. Thomas (1993) "Expression of functional papain precursor in Saccharomyces cerevisiae: rapid screening of mutants", Protein Eng. 6: 213-9.

Walreavens, V., M. Jaziri, J. van Beeumen, A.G. Schnek, T. Kleinschmidt \& Y. Looze (1993) "Isolation and preliminary characterization of the cysteine-proteinases 
from the latex of Carica candamarcensis Hook", Biol. Chem. Hoppe-Seyler 374: 501-6.

Westergaar, J.L., C. Hackbarth, M. W. Treuhaft \& R. C. Roberts (1980) "Detection of proteinases in electrophoretograms of complex mixtures", Journal of Immunological Methods 34: 167-75.

Whitaker, J.R. (1982) "Enzymes of importance in high protein foods", en "Use of enzymes in food technology" (P. Dupuy, ed.), Technique et Documentation Lavoisier, Paris, págs. 329-58.

Williams, D.C. \& J.R. Whitaker (1969) "Multiple molecular forms of Ficus glabrata ficin. Their separation and relative physical, chemical, and enzymatic properties", Plant Physiol. 44: 1574-83.

Williams, D.C., V.C. Sgarbieri \& J.R Whitaker (1968) "Proteolytic activity in the genus Ficus", Plant Physiol., 43: 1083-8.

Winnick, T., A.R. Davis \& D.M. Greenberg (1940) "Physicochemical properties of the proteolytic enzyme from the latex of the milkweed, Asclepias speciosa Torr. Some comparisons with other proteases, J. Gen. Physiol. 23: 275-88.

Winnick, T., W.H. Coney \& D.M. Greenberg (1944) "Experiments on the activation of ficin", J. Biol. Chem. 153: 465-70.

Wong, R.C., \& I.E. Liener (1964) "Amino acid sequence involving the reactive thiol group of ficin", Biochem. Biophys. Res. Commun. 17: 470-4.

Woo, K. M., W.J. Chung, D.B. Ha, A.L. Goldberg \& C.H. Chung (1989) "Protease Ti from Escherichia coli requires ATP hidrolysis for protein breakdown but not for hidrolysis of small peptides", J. Biol. Chem. 264: 2088-91.

Yonaha, K., S.D. Elliott \& T.Y. Liu (1982) "Primary structure of zymogen of streptococcal proteinase", J. Protein Chem. 1: 317-34. 